\author{
UNIVERSIDADE DE SÃO PAULO \\ FACULDADE DE FILOSOFIA, LETRAS E CIÊNCIAS HUMANAS \\ DEPARTAMENTO DE LETRAS MODERNAS \\ PROGRAMA DE PÓS-GRADUAÇÃO EM LÍNGUA ESPANHOLA \\ E LITERATURAS ESPANHOLA E HISPANO-AMERICANA
}

VANESSA ALVES MAXIMO DOS SANTOS

Quixotização e Sanchificação: abordagens críticas acerca da relação entre dom Quixote e Sancho Pança 


\begin{abstract}
UNIVERSIDADE DE SÃO PAULO
FACULDADE DE FILOSOFIA, LETRAS E CIÊNCIAS HUMANAS DEPARTAMENTO DE LETRAS MODERNAS PROGRAMA DE PÓS-GRADUAÇÃO EM LÍNGUA ESPANHOLA E LITERATURAS ESPANHOLA E HISPANO-AMERICANA
\end{abstract}

\title{
Quixotização e Sanchificação: abordagens críticas acerca da relação entre dom Quixote e Sancho Pança
}

Vanessa Alves Maximo dos Santos

Dissertação apresentada ao Programa de Pós-Graduação em Língua Espanhola e Literaturas Espanhola e HispanoAmericana do Departamento de Letras Modernas da Faculdade de Filosofia, Letras e Ciências Humanas da Universidade de São Paulo, para a obtenção do título de Mestre em Letras.

Orientadora: Prof. Dra. Maria Augusta da Costa Vieira

São Paulo

2009 
Catalogação na Publicação

Serviço de Biblioteca e Documentação

Faculdade de Filosofia, Letras e Ciências Humanas da Universidade de São Paulo

PCD

Santos, Vanessa Alves Maximo dos

Quixotização e Sanchificação: abordagens críticas acerca da relação entre dom Quixote e Sancho Pança / Vanessa Alves Maximo dos Santos; orientadora Maria Augusta da Costa Vieira. -- São Paulo, 2009. 123 p.

Dissertação (Mestrado - Programa de Pós-Graduação em Língua Espanhola e Literaturas Espanhola e Hispano-Americana do Departamento de Letras Modernas) Faculdade de Filosofia, Letras e Ciências Humanas da Universidade de São Paulo.

1. Cervantes, Miguel de 1547-1616 (Miguel de Cervantes Saavedra). 2. Sanchificação. 3. Quixotização. 4. Madariaga, Salvador de 1886-1978. 5. Estudos cervantinos. Título. II. Vieira, Maria Augusta da Costa. 
"Hay que tener en cuenta también que nuestras lecturas siempre implican, además del complejo de conocimientos y códigos interpretativos, nuestras identidades, sexo, color, edad, profesión, actitudes y experiencias de vida. Nuestra race, milieu, moment. Nuestro yo."

Carroll B. Johnson 


\section{Agradecimentos}

Agradeço à professora Maria Augusta da Costa Vieira a oportunidade, os ensinamentos que foram muitos, a confiança e o carinho demonstrado ao longo dessa trajetória.

À professora Ana Lúcia Trevisan que me mostrou o caminho.

À professora Joyce Rodriguez Ferraz a leitura deste trabalho.

A todos da secretaria do DLM, especialmente a Edite que sempre me atendeu com muita atenção e simpatia.

Aos companheiros do grupo Cervantes. Obrigada Ana Aparecida por sua ajuda amiga.

Por fim, agradeço muito ao Adamario, meu esposo, que me animou e me encorajou sempre. Aos meus amados filhos Victoria Maria e João Pedro a paciência com a mamãe. A minha mãe que tornou possível minhas idas à biblioteca, ficando com as crianças.

Obrigada, Senhor. 


\section{RESUMO}

Os estudos críticos especializados que dizem respeito à relação entre dom Quixote e Sancho Pança evidenciam a repercussão que teve, no âmbito dos estudos cervantinos, a abordagem proposta por Salvador de Madariaga y Rojo a respeito do processo de simbiose, processo lento e seguro, entre as duas personagens. O presente trabalho tem o objetivo de analisar a leitura crítica de Madariaga e os posteriores desdobramentos que seu viés de análise trouxe para o cervantismo. Para tanto, a dissertação concentrou-se na elaboração de um balanço crítico, tratando de resgatar algumas idéias relativas às tendências filosóficas e literárias que orientaram as leituras acerca do par quixotesco, concentrando-se nas abordagens que tiveram maior destaque ao longo do século XX e começo do século XXI, mais precisamente a partir de 1926 até os dias atuais.

Palavras-chave: Cervantes, Sanchificação, Quixotização, Madariaga, Estudos Cervantinos. 


\section{Abstract}

The specialized critical studies that concerning the relationship between don Quixote and Sancho Panza highlight the approach proposed by Salvador de Madariaga y Rojo about the symbiosis, slow and safe process, among the two characters repercussion in the Cervantine Studies. This work aims to analyze the critical reading of Madariaga and the subsequent developments that his bias of analysis has brought to the Cervantine Studies. To this end, the dissertation focused on a critical examination, bringing up some philosophical and literary readings about these two quixotic characters, focusing on the most prominent approaches over the twentieth and beginning of the twenty-first century, precisely from 1926 to the present day. Key-words: Cervantes, Sanctification, Quixotization, Madariaga, Cervantine Studies. 


\section{SUMÁRIO}

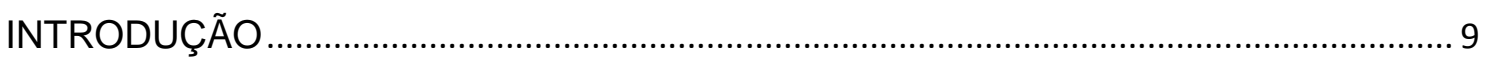

CAPÍTULO I - Panorama literário do principio do século XX ......................................... 12

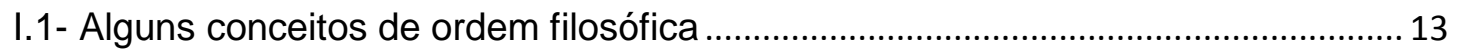

I.2- Escolas e estéticas literárias do princípio do século................................................. 21

I.3- Relação dom Quixote e Sancho Pança: as idéias de sanchificação e quixotização de Salvador de Madariaga y Rojo

CAPÍTULO II - Trabalhos críticos: a repercussão convergente da idéia de Madariaga

CAPÍTULO III - Outros enfoques. Propostas divergentes acerca do processo evolutivo e influência mutua das personagens dom Quixote e Sancho Pança. 74

CAPÍTULO IV - Perspectiva de leitura das (im)posturas de dom Quixote e Sancho Pança no capítulo XLI, da segunda parte

CONSIDERAÇÕES FINAIS.

BIBLIOGRAFIA 


\title{
INTRODUÇÃO
}

\author{
“- Ya vees, Sancho hermano, el largo viaje que nos \\ espera, y que sabe Dios cuándo volveremos dél, ni la \\ comodidad y espacio que nos darán los negócios; [...]"
}

dom Quixote (D.Q.II, p.330)

A epígrafe desta introdução refere-se a um pequeno trecho do capítulo XLI do segundo Quixote que trata do momento no qual o cavaleiro revela ao escudeiro suas profundas incertezas quanto à aventura que deverão empreender sobre Clavilenho. Dom Quixote refere-se em primeiro lugar à longa viagem que os espera, para depois comentar as duvidas acerca do regresso para, finalmente, referi-se aos eventuais benefícios que trarão a empresa. Com certa insegurança, no momento indicado, amo e escudeiro dão início à aventura.

A intenção principal neste trabalho é a de organizar um cenário em que se apresente a idéia da "sanchificação" de dom Quixote e da "quixotização" de Sancho proposta por Salvador de Madariaga y Rojo. Não se trata de uma análise pormenorizada da questão, mas de uma apresentação relativa aos conceitos tratados pelo autor que tiveram grande repercussão no âmbito dos estudos cervantinos. Busca-se assim evidenciar através dos estudos críticos acerca da relação das personagens, não só o que desencadeou na crítica literária a abordagem de Madariaga a respeito da simbiose entre dom Quixote e Sancho Pança, mas também como a idéia foi sendo apresentada por estudiosos que de algum modo problematizaram a questão. 
Antes de se chegar a este momento do trabalho foi necessário organizar um panorama cujo objetivo principal foi o de mostrar algumas tendências filosóficas e literárias que influenciaram expressivamente o modo de conceber a obra clássica no século XX.

Como em um jogo de dominó em que uma peça pressupõe a outra ainda que um dos lados seja diferente, ao vislumbrar a concepção de arte própria deste tempo e a concepção de arte própria da época de Cervantes viu-se a possibilidade de se ler as mudanças e transformações dos protagonistas quixotescos por um outro ângulo que não o proposto por Madariaga. Tendo isso em vista, os referencias próprios dos séculos XVI e XVII tais como, as Poéticas de Aristóteles e de Pinciano, viabilizaram essa outra maneira de conceber os movimentos ocorridos na relação amo/escudeiro no episódio relativo à aventura sobre Clavileño.

\section{QUANTO À DIVISÃO E OBJETIVO DOS CAPÍTULOS}

No capítulo I intitulado "Panorama literário de principio de século XX. Salvador de Madariaga y Rojo: conceitos de "sanchificação" e "quixotização"”, busca-se organizar um cenário onde algumas vertentes filosóficas e literárias estão presentes, a fim de evidenciar certas tendências identificadas nas abordagens críticas a partir de 1926, ano em que se publica o estudo de Madariaga.

No capítulo II intitulado "Trabalhos críticos: repercussão convergente da idéia de Madariaga", pretende-se fazer um recorte das opiniões críticas que compartilham da evolução e simbiose das personagens. Sendo assim, o objetivo principal, neste momento, é o de identificar nas análises críticas da obra literária as particularidades que evidenciam a convergência em relação ao tema proposto e como elas se estabeleceram. 
Tendo em conta essa perspectiva, pretende-se mostrar que a leitura do Quixote nas primeiras décadas do século XX foi feita pela crítica a partir de uma leitura interpretativa da obra de caráter impressionista. Manuel Azaña, em 1930, no texto "De Cervantes y la invención del Quijote”, referindo -se de modo particular a Miguel de Unamuno, diz: "En nuestros días, un gran entendedor del Quijote ejecuta a Cervantes en su magnitud de poeta, mediante una operación crítica muy personal[...]." 1

No capítulo III intitulado "Outros enfoques. Propostas divergentes acerca do processo evolutivo e influência mutua das personagens dom Quixote e Sancho Pança" traz algumas opiniões, que, depois de Madariaga, explicam a relação e conseqüentes oscilações entre amo e escudeiro, através de outros processos que não o da assimilação convergente. Dessa forma procede, por exemplo, L. Slestsjöe ${ }^{2}$, no texto Sancho Panza, hombre de bien, de 1961, o qual apresenta uma leitura literal das personagens do Quixote. L. Slestsjöe diz que Sancho não cresce, não evolui, mas muda bruscamente.

Por fim, no capítulo IV intitulado "Leitura das (im)posturas de dom Quixote e Sancho Pança no capítulo XLI, da segunda parte" trata-se de propor um caminho possível de análise do episódio da segunda parte da obra de Cervantes que se refere à aventura sobre o cavalo de madeira Clavileño, quando dom Quixote e Sancho Pança se submetem, mais uma vez, a um cenário fantasioso de burla e de mudança nas posturas comumente apresentadas.

\footnotetext{
${ }^{1}$ AZAÑA. Manuel. "Cervantes y la invención del Quijote" em Obras completas. Mexico, Oasis, 19661968

${ }^{2}$ SLETSJOE, L. Sancho Panza, hombre de bien, Madrid, Insula, 1961
} 


\section{CAPÍTULO I - Panorama literário do principio do século XX}

"Don Quijote crea su vida en un mundo donde es presencia constante la literatura. Ésta, que es representación de vida, hace resaltar con su contraste la vida del caballero, que llamamos humana, porque ésta consiste esencialmente en ir siguiendo la luz que proyectan camino delante de nuestras ilusiones y esperanzas."

Richard L. Predmore

Este capítulo possui dois objetivos principais: o primeiro diz respeito a um aspecto conceitual bastante presente nos estudos críticos cervantinos na primeira metade do século XX; o segundo refere-se às transformações que foram ocorrendo em relação a este mesmo aspecto. Em outros termos, o primeiro objetivo consiste na problematização dos conceitos da sanchificação de dom Quixote e da quixotização de Sancho Pança apresentados por Salvador de Madariaga y Rojo em seu Guía del lector del QUIJOTE (1926), a fim de verificar como as idéias de evolução e simbiose das personagens se estabeleceram ao longo do século XX. Trata-se, nesse sentido, de um balanço crítico relativo a este tema específico. O segundo objetivo, por sua vez, pretende identificar mudanças notáveis no modo de conceber a relação amo/escudeiro da primeira para a segunda metade do século XX. Como afirma Maria Augusta da Costa Vieira ${ }^{3}$ "Fica evidente que a história crítica do Quixote contém uma cisão radical entre dois períodos: da publicação até final do século XVIII e do século XIX até meados do XX.” Em suma, para melhor organizar o cenário crítico-interpretativo do Quixote, tendo em conta especificamente a relação Dom Quixote e Sancho, será necessário apresentar inicialmente alguns pressupostos da teoria literária que orientaram ao longo do século

\footnotetext{
${ }^{3}$ VIEIRA. Maria Augusta da Costa. Dito pelo não dito : paradoxos de Dom Quixote. São Paulo. Edusp. 1998, p.65
} 
passado a leitura da obra de Cervantes. As tendências filosóficas e literárias, em tese, direcionam os diferentes modos de leitura acerca da relação do par quixotesco.

\section{I.1- Alguns conceitos de ordem filosófica}

A crítica literária do século XX se destacou, em tese, fundamentalmente por meio da relação conflitiva/harmoniosa com as escolas e estéticas literárias do princípio do século. Muito do pensamento estético literário do século XX tem suas diretrizes originadas na filosofia do século XVIII. Destaca-se, Emmanuel Kant ${ }^{4}$, como trata Luisa López Grigera, no estudo intitulado "Historia textual: Textos literários (Siglo de Oro)".

\section{LUISA LÓPEZ GRIGERA}

Cabe atenção ao trabalho de Luisa López Grigera, pois nele a autora ressalta alguns traços abalizados no século XX para a arte e para o artista. Trata-se de um artigo onde a autora afirma que as idéias de espontaneidade e criação são provenientes das teorias kantianas, afirma Grigera:

las teorías kantianas ponían la grandeza de la poesía en la inspiración, la espontaneidad y la improvisación, mientras que desde la antiguedad hasta no hace mucho la formación que recebía el escritor era la misma: teorías retórico-poéticas y comentario de clásicos, cuya imitación se recomendaba como el camino más seguro para lograr al original. (GRIGERA. p.1)

Em âmbito geral, a partir da nova tendência para a arte/artista, segundo Grigera, o escritor passa não mais a se pautar nos conceitos outrora estabelecidos pelas teorias retórico-poéticas e outros preceitos clássicos. No novo cenário proposto, nas últimas décadas do século XVIII, pela filosofia kantiana, a arte e o modo de concebê-la passam a trilhar caminhos que favorecem o talento inato, o gênio e a inspiração.

\footnotetext{
${ }^{4}$ Data de nascimento de Kant 1724 e de Hegel 1770.
} 
Para não muito estender, Luisa L. Grigera ao longo de sua exposição deixa evidenciado dois períodos históricos para a obra literária, ou seja, o período anterior a Kant, quando se primava pela composição e pela imitação dos clássicos e o período pósKant, quando o valor está na arte de criar com liberdade, sem regras pré- estabelecidas. Grigera prossegue com seu trabalho tendo em conta as preceptivas poéticas características do Século de Ouro. A autora dedica atenção aos estilos (os gêneros) mais comumente utilizados no mencionado período.

\section{EMMANUEL KANT}

Com respeito a algumas idéias de Kant para a arte, em linhas muito gerais, na Crítica del Juicio Kant apresenta logo no início de sua exposição os conceitos da natureza e da liberdade que são a essência estruturante dos princípios filosóficos. A esse respeito, explica Kant: "no existe más que dos espécies de conceptos, los cuales llevan en si otros tantos principios diferentes; estos conceptos son los de la naturaleza y de la libertad". (KANT, Crítica del Juício, p.1). O domínio da liberdade é, segundo o filósofo, a prática do conhecimento teórico que emerge da natureza do ser humano. Kant se refere à natureza como um lugar onde repousa o sensível, onde nada se organiza por si só, mas pelo que advém da experiência. A partir dos conceitos de natureza e liberdade o esquema do pensamento crítico kantiano se consolidará na trilogia: Crítica da razão pura, Crítica da razão prática e, a que caberá neste estudo, Crítica do Juízo.

Na Crítica do Juízo Kant desenvolve sua proposta acerca da estética na arte por meio do significado metafísico do belo, da natureza do gosto até chegar à crítica da faculdade do juízo teleológico. Para o filósofo, nenhum conceito se sobrepõe ao outro, cada qual possui sua própria legislação, tendo o Juízo como laço que une harmoniosamente tais faculdades. "un término medio entre el entendimiento y la razón: este término médio es el Juicio. (Kant, E. Crítica Del Juicio, p.4, da Biblioteca Virtual). 
As idéias propostas na Crítica do Juízo (1790) fomentaram uma nova tendência na concepção da arte, por conseguinte do artista. Em 1764 Kant apresenta um pequeno estudo intitulado Observações sobre o sentimento do belo e do sublime, que trata de algumas observações de ordem antropológica sobre os comportamentos dos seres humanos na sociedade. Nas Observações Kant se preocupará em diferenciar, sem aprofundar, como afirma o próprio autor nas primeiras páginas do trabalho, o par belo/sublime nas condutas humana e social: "Aqui lanço meu olhar, mais de observador do que de filósofo, apenas sobre alguns pontos que parecem apresentar-se como relevantes nessa área." Cabe notar que se trata de categorias valorativas, como se refere $\mathrm{Kant}^{6}$, as quais possuem certa oposição estruturante que servem para acentuar graus de sociabilidade, gosto e entendimento humano.

Kant retomará na Crítica do Juízo, por um lado, conceitos ora tratados nas críticas anteriores, tal como o significado da filosofia e sua importância para o conhecimento humano, por outro lado, encerrará idéias acerca do belo e do sublime. Concepções estas notoriamente mais trabalhadas e difundidas do que a abordagem dada nas Observações sobre o sentimento do belo e o sublime. Para tanto, Kant se debruçará, em especial, sobre a finalidade e a essência do par belo/sublime, suas manifestações no entendimento humano e no exercício da arte sem deixar velada a importância do gosto cujos princípios são subjetivos. A esse respeito afirma Kant:

En efecto; en todo esto no hay otra cosa que lo agradable en el sentimiento mismo de nuestro estado; y como en definitiva, nuestras facultades deben dirigir todos sus esfuerzos hacia la práctica, y unirse en este fin común, no podemos atribuirles otra estimación de las cosas, que la que consiste en la consideración del placer prometido. (KANT,1993,p.3)

\footnotetext{
${ }^{5}$ KANT. Emmanuel. Observações sobre o sentimento do belo e do sublime ensaio sobre as doenças mentais. 1993, p.19

${ }^{6}$ Idem, 1993, p.11
} 
Dessa maneira, a partir do trato conferido às categorias estéticas, $\mathrm{o}$ filósofo alemão lança-se na idéia de "gênio" cujas características essenciais são a espontaneidade e a subjetividade para a arte. Como ele próprio diz, "el genio consiste propiamente en una feliz relación de la imaginación y el entendimiento, que ninguna ciencia nos puede enseñar, ninguna aplicación nos puede dar.” (Cáp. XLIX,1993, p.3)

O gênio possui originalidade exemplar e própria, ademais seu talento é natural e livre para escolher nas diferentes faculdades do pensamento as regras necessárias para seu trabalho artístico e/ou literário.

Em suma, algumas das idéias apresentadas por Kant na Crítica do Juízo serão retomadas e ampliadas por estéticas filosóficas posteriores, tal como faz Hegel em sua Estética. Em contrapartida poetas, romancistas e artistas conceberam radicalmente a prática do exercício da genialidade no século XIX e princípios do século XX, no Ocidente. Essa filosofia se reflete na criação da obra literária e nas leituras críticas do século passado.

\section{HEGEL}

Seguindo o pensamento kantiano, o contemporâneo Hegel (1993, p.24), em sua Estética, afirma que o gênio e o talento são, pelo menos em certo aspecto, dons naturais. Com o objetivo de ilustrar o que foi dito até então, em nota introdutória da Estética hegeliana se tem a seguinte observação: "Prevaleceu esta opinião durante o período chamado da genialidade, iniciado na Alemanha pelas primeiras obras de Goethe e de Schiller" (HEGEL.1993, p.24) O filósofo acrescenta um dado interessante à proposta kantiana, ou seja, na visão de Hegel, o gênio para ser fecundo tem que possuir pensamento disciplinado e um exercício diário.

Pertencente então ao círculo pós-kant, Hegel em sua filosofia estética combina valores apresentados na Crítica do Juízo, tais como o talento existente na subjetividade 
do "eu", a essência do belo em conformidade com o objeto e o observador. Para tanto, explica Hegel "[...] a actividade do espírito não se exerce gratuitamente por uma determinação imposta: o espírito tem em si próprio a sua determinação, só a si próprio subordina o seu trabalho.” (HEGEL.1993, p.24)

Hegel dialoga com seu contemporâneo ao compartilhar da opinião de que a ordem do real segue a ordem da idéia, do pensamento, entretanto ao retificar alguns conceitos da ideologia kantiana, o filósofo faz emergir a sua própria ideologia ao passo de se destacar como um dos mais importantes pensadores da modernidade.

O princípio filosófico de Hegel se distingue da filosofia kantiana no que diz respeito ao principio absoluto das origens do ser e do conhecer cujo idealismo é radical, pois a idéia é a causa do mundo objetivo. Diferente de Kant que pretendeu com a noção de conceitos a priori, onde cada qual tem seu domínio no ser e na natureza, calcar sua filosofia. "El uso de nuestra facultad de conocer por medio de principios, o sea la filosofia, no reconoce más límites que los de la aplicación de conceptos a priori”7.

Em linhas gerais, outro aspecto interessante na estética desenvolvida por este filósofo é a chamada dialética hegeliana, a qual diz respeito a três unidades primordiais: a tese, a antítese e a síntese que suscita no entendimento da identidade dos opostos, ou seja, o surgimento de tudo que há no mundo a partir do pensamento que é o próprio real. "Por conseguinte, a Idea é o único real, o princípio de tudo, a própria essência de todas as coisas existentes, e das inexistentes enquanto inexistentes". (HEGEL. p.XVII). Nesse sentido, tudo que há posteriormente terá uma relação direta e opositiva com o anterior, proporcionando o surgimento/explicação do novo, por meio do silogismo e da

\footnotetext{
${ }^{7}$ Kant. Crítica del Juicio, "Del dominio de la filosofia en general."
} 
razão que é conceitual e abstrata Hegel desenvolve sua filosofia. "E por este conflito, que existe dentro de cada realidade, se origina, necessariamente, a realidade nova."

Essas observações são possíveis de se identificar no modo de leitura dos românticos acerca do Quixote. A esse respeito o estudioso Chevalier" infere que "os críticos românticos depreendiam da obra cervantina o conflito entre o prosaísmo e a poesia; a realidade e o ideal; dom Quixote e a sociedade: posturas opositivas/conflitivas de que dom Quixote e Sancho Pança eram figuras de antitética simetria.”

O modo opositivo de apreender o par quixotesco perdurou por um grande período na crítica cervantina, marcando ainda os textos críticos das primeiras duas décadas do século XX.

\section{CERTO ASPECTO DA TENDÊNCIA ROMÂNTICA}

El Romanticismo, que enarbola la juvenil bandera de la libertad "expresiva" del yo, trata de acabar con esa vieja maestra del arte de hablar y escribir con perfección: arte de convencer, de mover e de deleitar. Luisa López Grigera (1994, p.87)

Amparados por estas e outras filosofias, os românticos entendiam que a beleza estava contida na interioridade como tal, na subjetividade infinita de cada ser, por isso deveria ser representada por um individuo provido de um saber e de um querer inerente a ele. Isso não quer dizer que a percepção romântica não passasse pela realidade ou que fosse inteiramente retirada do subjetivo - não, a subjetividade artística/ literária coteja a realidade, mas a diferença com o clássico está no direcionamento tomado, ou seja, a arte experimenta o exterior, pauta-se nele para representar seu valor intrínseco, mas retorna ao interior, ou seja, à subjetividade que segundo Hegel, “é a luz espiritual que a si mesma se ilumina, que brilha onde antes só havia escuridão.” (HEGEL, p.293)

\footnotetext{
${ }^{8}$ NÓBREGA. Francisco Pereira de. Compreender Hegel. 2005, p.43

${ }^{9}$ CHEVALIER. Maxime. Actas del Segundo Congreso Internacional de la Asociación de Cervantistas. Alcalá de Henares, 1989
} 
Com efeito, essência da escola romântica foi a subjetividade do 'eu" em contraposição ao racionalismo clássico onde a natureza do conteúdo e da forma se harmonizavam, a fim de melhor apresentar e representar o significado do belo na arte em si mesma. Segundo Maria Augusta da Costa Vieira, em o Dito pelo não dito: paradoxos de DOM QUIXOTE, os estudos cervantinos foram radicalmente alterados a partir das idéias do Romantismo Alemão.

Close na parte introdutória a La concepción romántica del QUIJOTE, em linhas gerais, diz que os românticos alemães consideravam o Quixote como um romance simbólico cujo simbolismo expressava várias idéias sobre a alma humana e a realidade e também sobre a natureza da história da Espanha.

Diante disso, o entendimento da obra como uma composição artística operada pela racionalidade ${ }^{10}$ é deixada de lado para dar lugar à criação, que baseada na subjetividade, na espontaneidade e na originalidade favoreceu o entendimento da arte. Em harmonia com as teorias filosóficas a crítica cervantina concebeu o Quixote na primeira metade do século passado, desconsiderando o conjunto de preceptivas retóricopoéticas que orientaram as composições literárias nos séculos XVI e XVII. Segundo explica Alexia Dotras Bravo os neoclássicos ainda se aproximavam mais da interpretação paródica do Quixote, no entanto a partir de autores como Benjumea, 1859, e das correntes filosóficas os estudos críticos tomaram outro rumo.

Para concluir, um dos pensamentos repercutidos no século XIX e ainda em meados do XX foi o valor do "eu", do "eu" e a sociedade, de suas inquietudes e insatisfações. Aspectos que refletiram expressivamente no modo de conceber o Quixote, ou seja, a obra em si corresponde aos anseios humanos. Como apresenta Dotras Bravo,

\footnotetext{
${ }^{10}$ Termo que se refere ao estudo e manuseio das preceptivas de arte dos séculos XVI e XVII e que serve de oposição ao subjetivo e simbólico.
} 
Algunas aproximaciones a la novela anteriores al ensayo de Salvador de Madariaga se posicionan en la concepción de la novela y de los personajes como amigos[...], espécie de novela-ensayo que pretende explicar, a veces casi filosóficamente, desde perspectivas subjetivas la obra maestra cervantina."11

\section{GEORG LUKÁCS: QUIXOTE COMO PRIMEIRO ROMANCE MODERNO}

As abordagens críticas do século XX apreendem do Quixote as diretrizes do romance moderno. Parte dos estudiosos considera a obra cervantina como a primeira do gênero. A respeito dessa afirmação, Anthony Close considera esse modo de aproximação bastante influente para as interpretações do período. Como apresenta Close,

Poco después de que Ortega desbrozara el camino, Lukács publicó su Teoría de la novela (1920), que ejerció gran influencia en Europa, aunque tardó bastante tiempo en llegar a conocimiento de los estudiosos del Quijote. [...] el libro de Lukács parte de la tesis hegeliana de que en la épica cristaliza la cosmovisión de la Antigüedad, al presentar un cuadro idealizado y heróico de un pasado en el que había armonía y comunicación entre las esferas humana y divina; al perderse la fe primitiva en la realidad del mundo transcendental nace la novela moderna, con el Quijote. (CLOSE, A., 2005.p.258)

Georg Lukács, pensando na problemática dos gêneros épico e moderno, demonstrou seu entendimento acerca da essência do romance. Segundo o filósofo, o romance moderno se caracteriza pelo "eu" em desarmonia com o mundo, ou seja, o "eu" está em busca de si mesmo. Gênero onde o herói não compartilha da totalidade do mundo, o herói se identifica com a consciência individual.

Em resumo, a perspectiva de Lukács fomentou, como tratou Close, profundamente na visão do Quixote como primeiro romance moderno, dito de outro

\footnotetext{
${ }^{11}$ BRAVO DOTRAS. Alexia. Los trabajos cervantinos de Salvador de Madariaga Historia de una idea doble: sanchificación y quijotización, 2008 p. 38
} 
modo, Lukács explica a tipologia do romance, tendo como referência o Quixote. Com efeito, o objetivo é caracterizar o romance moderno, que segundo o estudioso se diferencia pelo protagonista detentor de mentalidade/identidade desintegrada. Explica Lukács, "O romance é a epopéia de uma era para a qual a totalidade extensiva da vida não é mais dada de modo evidente, para a qual a imanência do sentido da vida tornou-se problemática [...]" (LUKÁCS. Georg. Teoria do Romance. p.55).

\section{I.2- Escolas e estéticas literárias do princípio do século}

\section{FORMALISMO RUSSO}

Escolas e estéticas literárias do princípio do século firmaram novas diretrizes acerca do texto literário, possibilitando uma leitura mais técnica e menos interpretativa; mais embasada nos procedimentos narrativos e menos na visão simbólica do texto. A primeira contribuição nesse sentido foi a abordagem teórica proveniente do Formalismo Russo, surgido, entre 1914 e 1917, na Rússia, quando alguns estudantes fundaram o Círculo Lingüístico de Praga e a Associação para o Estudo da Linguagem Poética (OPOIAZ) -1917. A finalidade dos grupos formados era o aprimoramento dos estudos relacionados com a língua e a literatura.

Quanto à origem, o Formalismo teve início com o Círculo Linguístico de Praga, segundo indica Todorov, no trabalho "Herança metodológica do Formalismo", foi uma das primeiras escolas de lingüística estrutural.

O conjunto de processos e técnicas elaborados pelos estudiosos formalistas serve à descrição da obra literária e a isso se denomina "Método formal" cujo objetivo foi estabelecer critérios científicos para o estudo do poema e da prosa literária. Embora a teoria formalista tenha alterado de maneira significativa os estudos literários, a escola 
tendeu ao enfraquecimento, pois não conseguiu consolidar um sistema teórico que pudesse ser admitido de modo geral. Apresenta Todorov, "sua doutrina está em constante elaboração, o grande mérito dos estudos formalistas é a profundidade e a finura de suas análises concretas, mas suas conclusões teóricas são muitas vezes mal fundadas.” $(1979$, p.28)

De modo geral, os formalistas, segundo artigo "Formalismo Russo e New Criticism”, de Arnaldo Franco Junior, em seu Teoria literária: abordagens históricas e tendências contemporâneas preocupavam-se em investigar e explicar o que faz de determinada obra uma obra literária. Ou seja, a preocupação dos formalistas era estritamente a consideração do texto pelo texto, o texto e seu procedimento. Arnaldo Franco Junior ("Formalismo Russo e New Criticism", 2003, p.95) cita Jakobson quando diz que o objeto do estudo literário é a literariedade do texto, ou seja, o processo pelo qual o texto passa a configurar sua materialidade, diz o autor: "Nesse sentido, a importância dada a distinções que se baseiam em valores extras literários torna-se secundária em relação ao valor das distinções calcadas em valores exclusivamente literários." 12

O Formalismo Russo chama atenção para outra vertente de análise da obra literária. Para tanto, os formalistas pareciam ir de encontro com preceitos da tradição acadêmica em que tudo servia para entender e interpretar a obra literária, isto é, os costumes, a psicologia, a política, a filosofia eram recursos fundamentais das análises dos estudiosos em princípios do século XX. A crítica literária apoiada em outras ciências encontrava, dentre elas, o instrumento necessário para sustentar as análises críticas. Os historiadores da literatura, assim denominados, "podíamos comparar [...] a

\footnotetext{
${ }^{12}$ JUNIOR. Arnaldo Franco. "O formalismo Russo e o New Criticism" em Teoria literária: abordagens históricas e tendências contemporânea. 2003, p.96
} 
esta polícia que se propondo a prender qualquer um, apanhava ao acaso todo aquele que ela achava no quarto" (EIKHENBAUM, Teoria da literatura: formalistas rusos. 1976, p.8). Dito de outra maneira, estes estudiosos se utilizavam dos costumes, da vida pessoal, das ciências como forma de apreender a obra literária. Para Boris Eikhenbaum, "Compunha-se um aglomerado de disciplinas gastas em vez de uma ciência literária" (EIKHENBAUM. 1976, p.8)

Em lugar de um estudo da literatura, criava-se um conglomerado de disciplinas mal acabadas [...] deste modo, o movimento voltava-se não só contra os excessos de crítica sociológica e política, da submissão da estética à ética [...] contra a metafísica e a religiosidade [...] (SCHNAIDERMAN, 1976, p.X)

Distanciados, portanto, da perspectiva subjetiva frente ao texto, o modelo teórico literário de estudo apresentado pelos formalistas ia de encontro com a tradição crítica. A isso se refere Eikhenbaum quando verifica os "[...] princípios estéticos subjetivos [...] à exigência de uma atitude científica e objetiva em relação aos fatos [...]. O próprio estado das coisas nos pedia que nos separássemos da estética filosófica e das teorias ideológicas da arte.” (EIKHENBAUM. 1976 pgs. 7-8). Os Formalistas Russos segundo Schnaiderman, no prefácio da Teoria da literatura: formalistas russos se recusavam a fazer uso de interpretações (extra)literárias do texto, uma vez que o objetivo para esses estudiosos é exclusivamente a literatura e suas especificidades intrínsecas. Nesse sentido, os formalistas acreditavam que um dos caminhos para apreender a obra literária seria a retomada da poética, a fim de servir como fundamento para a análise literária. Essa postura marcou categoricamente a nova concepção crítica, pois a teoria formalista rompeu com o modelo historicista de leitura e, por isso se faz importante na história da crítica literária do século passado. "Durante nossos anos de estudo, a história acadêmica 
da literatura se limitava de preferência ao estudo biográfico e psicológico dos escritores isolados [...]" (EIKHENBAUM, 1976,p.32)

A escola formalista, ao longo dos anos, se dedicou essencialmente à análise da poesia, pois nela podiam distinguir concretamente os planos de composição, tais como: fônico, métrico, etc. Embora o gênero em verso fosse o instrumento dos estudos formalistas, Chklovski, como se refere Eikhenbaum, deu atenção em alguns trabalhos ao procedimento narrativo, ou seja, à prosa. Mostra disso é o trabalho Una teoria della prosa, tradução para o italiano, versão de 1966, edição da Opoiaz, de 1921. Neste estudo Chklovski verifica a relação entre procedimento e motivação no Quixote, pois entende que a obra contém elementos imprescindíveis para o entendimento do romance enquanto gênero.

Em linhas gerais, o autor considera a obra de Cervantes como um intermediário entre a reunião de novelas e o romance de um único herói. Desse modo, estudiosos como Eikhenbaum e Chklovski procuravam demonstrar a existência de procedimentos próprios em cada composição literária e a ligação com procedimentos estilísticos gerais.

\section{ESTRUTURALISMO}

Por volta de 1940, com os estudos de Claude Lévi-Strauss, pesquisador dedicado ao estruturalismo antropológico e precursor do estruturalismo literário se estabelece o novo modelo de análise textual, ratificando o distanciamento com o modelo de análise historicista e confirmando as novas tendências críticas literárias do século XX. Isso posto, a partir das idéias formalistas e da Escola de Praga o iminente interesse pelo o estudo das estruturas do texto emergiu. Para tanto, se apresentaram estudiosos tais como (em ordem aleatória) Todorov ${ }^{13}$; Barthes, Bremond, Propp, Greimas, os quais

\footnotetext{
${ }^{13}$ Para T. Todorov a obra literária é o objeto último e único. “[...] não é considerada como manifestação de uma estrutura inconsciente ou de uma concepção filosófica, mas como um discurso que se faz conhecer por si mesmo.” TODOROV. Tzvetan. Estruturalismo e poética. pgs. 11-12
} 
aprimoraram a teoria estruturalista. Interessados por esse tipo de abordagem acabaram por se desvencilhar da intenção conhecida dos formalistas que era alinhar forma e conteúdo. "Para os estruturalistas, a estrutura é a condição para que o significado seja compreendido."14

Em tese, de um lado, os estruturalistas preocupavam-se com o estudo das estruturas do texto para apreender o significado de um texto, por outro lado, a perspectiva humanista de análise ocupava-se da leitura da obra literária para compreender a realidade social, política, etc. Nesse sentido, a escola estruturalista chama atenção para "uma prática interpretativa que procura certa ordem e inteligibilidade nas inúmeras possibilidades de padrões de texto [...] poderá chegar a conclusões sobre significado e a cultura que estão sendo transmitidos e pesquisados."15

Fica evidente que os formalistas e os estruturalistas trataram de categorizar as partes constituintes da narrativa, afastando-se das posturas biografistas e psicologistas. O panorama identificado nas primeiras décadas do século XX parece marcado por duas fortes tendências: a primeira tendência se evidencia por estudiosos que se relacionavam com o texto de modo mais pessoal, abordando as personagens como se pertencessem ao mundo real. A segunda tendência frente ao texto evidencia estudiosos cujo critério analítico/técnico era o meio eficaz de se apreender a essência do texto literário. Contudo, desde os formalistas e desde os estudos estruturalistas as perspectivas críticas se destacam pelos procedimentos e métodos para o texto literário. A nova direção dada à leitura do Quixote também encontra fundamentos concretos nas orientações técnicas literárias do inicio do século.

\footnotetext{
${ }^{14}$ BONNICI, Thomas. "Teorias estruturalistas" p.108 em BONNICI, Thomas; ZOLIN, Lucia Osana. (orgs). Teoria Literária: abordagens históricas e tendências contemporâneas

${ }^{15}$ Idem, p. 110
} 


\title{
I.3- Relação dom Quixote e Sancho Pança: as idéias de sanchificação e quixotização de Salvador de Madariaga y Rojo
}

\author{
"Y así, interpenetrados por un mismo espíritu, se van \\ aproximando gradualmente, mutuamente atrayendo, por virtud de una \\ interinfluencia lenta y segura que es, en su inspiración como en su \\ desarrollo, el mayor encanto y el más hondo acierto del libro."
}

Salvador de Madariaga

Como começar este segundo momento do capítulo senão dizendo do interesse pela relação entre dom Quixote e Sancho Pança constituída a partir de dois paradigmas aparentemente estáveis ${ }^{16}$ que se desestabilizam consideravelmente ao longo da narrativa, proporcionando ao leitor o interesse em saber se os deslocamentos no discurso, na convivência e no ethos incorrerão na transformação radical ou parcial, ou ainda, se não incorrerão em transformação nas personagens, mas em possível aprendizado. Tal empenho parece ser despertado em boa parte dos leitores quixotescos, desse modo por se tratar de uma obra cuja idade é de quatrocentos anos a dedicação ao estudo do trato conferido ao par amo/escudeiro alcança proporções visíveis ao longo de quase um século de análises e de discussões acerca do tema. Tendo isto em vista, buscar quem tratou o assunto e como tratou do assunto, ou seja, apresentar o primeiro a chamar atenção de modo sistemático para as mudanças no caráter de amo/escudeiro a partir do entrecruzamento (conceito que vai de encontro com a proposta antinômica e simbólica dos românticos alemães) é o ponto de partida deste estudo.

\footnotetext{
${ }^{16}$ Os capítulos I e VII, da primeira parte do Quixote, exibem as características fundamentais de cada personagem que em tese serão conformadas ao longo de toda a narrativa. No entanto, ocorrem mudanças no comportamento e no discurso de amo/escudeiro, as quais puderam ser justificadas por meio da simbiose e da correspondência entre as personagens. "En un lugar de la Mancha [...] vivía un hidalgo de los de Lanza en astillero, adarga antigua, rocín flaco y galgo corredor."(D.Q. I, p.97) “[...] un labrador vecino suyo, hombre de bien, pero de muy poca sal en la mollera." (D.Q. I, p.142)
} 
Desde o começo, quando se pensava no trabalho aqui presente, pretendia-se verificar como os conceitos propostos por Madariaga foram recebidos pela crítica, entretanto faltava saber como conduzir tal balanço crítico literário. Para tanto, dois trabalhos alicerçaram de maneira especial os pontos apresentados. No primeiro semestre de 2007, lendo o artigo "Miguel de Cervantes e o Quixote: de como surge o romance"17, do prof. Montero Reguera, observou-se a indicação do trabalho intitulado "Don Quijote está sanchificado el des-sanchificador que lo re-quijotice...”, de José Manuel Martín Morán, publicado em 1992. Martín Morán chama a atenção para o estudo da história crítica da idéia de evolução das personagens, uma vez que até então não se havia feito nada nesse sentido. $\mathrm{O}$ artigo veio ao encontro da intenção inicial, entretanto faltavam ainda dados fiéis com respeito à vida e à obra de Salvador de Madariaga, cabe demonstrar a dificuldade de se encontrar, ora nas bibliotecas, ora na internet alguns trabalhos, os quais confiariam um pouco mais a questão ideada. Prosseguindo, sem notícias preliminares, no ano de 2008 foi publicado o estudo pormenorizado de Alexia Dotras Bravo, Los trabajos Cervantinos de Salvador de Madariaga historia de una idea doble: sanchificación y quijotización cujo acesso foi possível no segundo semestre do mesmo ano, por intermédio de Maria Augusta da Costa Vieira.

Em seu trabalho Alexia apresenta com categoria e divide entre quatrocentas páginas o breve panorama histórico da Espanha, desde os reis católicos até a ditadura franquista; a interpretação do Quixote na transição do século XIX(marcado pela tendência romântica) para o século XX, ainda ressalta a importância dos estudos psicológicos na Espanha, ciência destacada para os trabalhos de Madariaga a respeito das personagens cervantinas. Tudo antes de adentrar no estudo pormenorizado da vida e

\footnotetext{
${ }^{17}$ VIEIRA. Maria Augusta da Costa (org.). Dom Quixote: a letra e os caminhos. São Paulo. Edusp. 2006, p. 17
} 
obra de Salvador de Madariaga. Alexia Dotras Bravo se pauta no legado deixado por Salvador de Madariaga ao "Instituto José Cornide de Estudios Coruñeses", onde tem acesso a cartas, a artigos publicados, aos rascunhos de trabalhos do escritor e a obras cujas edições variam. A autora acrescenta que

Todos sus papeles están depositados en trescientos treinta y siete archivadores gruesos ordenados según la división que estimo oportuna el grupo de investigadores que catalogó los papeles del coruñes durante dos años, desde 1993 hasta $1995 .^{18}$

A terceira parte da obra intitulada "La repercusión de Guía del lector del QUIJOTE. Sanchificación y quijotización en la crítica desde 1926”,em particular chamou atenção, pois reforça definitivamente a importância do que se pretende estabelecer nesta dissertação, além de ratificar a sugestão de José Manuel Martín Morán a respeito de um estudo acerca da repercussão da sanchificação de dom Quixote e quixotização de Sancho, desde 1926.

Anos anteriores à proposta de Salvador de Madariaga acerca da sanchificação de dom Quixote e quixotização de Sancho Pança conceitos que remetem à integração dos valores estéticos das personagens protagonistas do Quixote ou chamada simbiose, o literato italiano Paolo Savj-Lopez se destacou no sentido de responder à proposta dos românticos alemães quanto ao modo de conceber os protagonistas quixotescos no princípio do século. Como observa Anthony Close,

El movimiento romántico definió el tema de Quijote de suerte que coincidia con una de las inquietudes esenciales de su metafísica, su estética y su arte: la oposição entre sujeto y objeto, mentes y naturaleza, espíritu y matéria, y las esferas de la libertad y la necesidad. $^{19}$

\footnotetext{
${ }^{18}$ BRAVO DOTRAS. Alexia. Los trabajos Cervantinos de Salvador de Madariaga historia de uma idea doble: sanchificación y quijotización. Alcalá de Henares. Centro de estúdios cervantinos. 2008, p.113

${ }^{19}$ CLOSE. Anthony. La concepción romântica del QUIJOTE. Barcelona. Crítica. 2005, P. 60
} 
Paolo Savj-Lopez ${ }^{20}$ (1876-1919) em um trabalho de 1913, Cervantes, chamava atenção para as diversidades no caráter de Sancho Pança, para a lenta transformação da personagem a partir da influência/relação com o amo, afirmava que eram figuras de diversas naturezas, as quais possuíam sonhos e compartilhavam os mesmos acontecimentos. Como se refere José Manuel Martín Morán "uno de los primeros en reaccionar contra la bipolaridad había sido Savj-López[...]”. A isso acrescenta Alexia Dotras Bravo ao afirmar que:

Savj-López habla de actitudes paralelas, donde ambos aspiran a sueños y viven los mismos sucesos '[...]. No son dos símbolos contrapuestos, sino dos diversas naturalezas cómicas', lo cual se confirma con la evolución de Don Quijote y Sancho[...](Pgs. 98-99).

Embora a idéia evidenciasse outra leitura sobre a relação amo/escudeiro não ganhou força, tampouco obteve repercussão. Quem nomeou, explicou e estruturou as oscilações no caráter, ou melhor, na relação entre amo/escudeiro foi Salvador de Madariaga.

Nota sobre SALVAdor de MADARIAGa E ALGUnS TRAÇOS COMPOSITIVOS DA OBRA GUÍA DEL LECTOR DEL QUIJOTE

Salvador de Madariaga y Rojo autor da obra Guía del Lector del QUIJOTE, nascido em La Coruña, em 23 de Julio de 1886 e falecido em Dezembro de 1978, na Suíça. "Ingeniero de formación, escritor de vocación y filólogo por aproximación, forma parte del mundo cultural e intelectual español y Europeo de principios de siglo XX"21. Foi engajado nas questões sociais e políticas de seu país e de outros países da Europa, onde permaneceu boa parte de sua vida. Expressou os ideais sociais, políticos e literários (em voga temas de sentimento nacional), ao longo de sua existência por meio

\footnotetext{
${ }^{20}$ SAVJ-LOPEZ. Paolo. Cervantes. Napoli. Ricciardi, 1913, p.32.

${ }^{21}$ BRAVO DOTRAS. Alexia. Los trabajos Cervantinos de Salvador de Madariaga historia de una idea doble: sanchificación y quijotización. Alcalá de Henares. Centro de estúdios cervantinos, 2008, p.102
} 
de artigos para jornais, ensaios, palestras/cursos em renomadas universidades da Europa e, não deixando de lado, a participação em programas radiofônicos, ${ }^{22}$ retornou à Espanha por pouco tempo, depois da morte de Franco. "Regresa a España trás la muerte de Franco, con noventa años, ya que por su oposición al régimen y su participación destacada en el gobierno de la República, había tenido que huir del país y se había negado a volver en vida del dictador.” (DOTRAS BRAVO, 2008,p.111).

Guía del Lector del QUIJOTE, segundo Dotras Bravo(2008,pgs.120-123) foi o único livro de crítica de maior extensão do autor sobre Cervantes, foi publicado em primeira edição, no ano de 1926, pelas editoras Aguilar e Espasa-Calpe. Interessante observar a repercussão do autor e de seus trabalhos em países da Europa, tais como Inglaterra e França e também na América Latina, uma vez que a editora ${ }^{23}$ Sudamericana, em Buenos Aires, dedicou-se em difundir as obras do escritor durante o período de exílio e posteriormente. "Una de las editoriales encargadas de difundir la cultura española en el exílio [...]" (DOTRAS BRAVO, p.121).

Para o presente trabalho foi utilizado Guía del Lector del QUIJOTE: ensayo psicológico sobre el QUIJOTE, prólogo de Luis María Ansón, terceira edição da EspasaCalpe, do ano de 1987.

Em meio aos textos que compilam o Guía del Lector del QUIJOTE boa parte deles dedica atenção aos conceitos de "sanchificação" de Quixote e "quixotização" de Sancho Pança. Madariaga destaca a importância de uma perspectiva flexível para entender as personagens centrais do Quixote. Segundo Dotras Bravo tais denominações

\footnotetext{
${ }^{22}$ Na pagina 120 da obra de Alexia Bravo, a autora menciona dois momentos de interesse do autor pela obra cervantina, a primeira depois da publicação da Guía del lector de QUIJOTE, fazendo crer no aprimoramento das reflexões. A segunda parece ser anterior à publicação da obra. Como a tão mencionada palestra na universidade de Cambridge e anotações para as aulas na universidade de Oxford.

${ }^{23}$ Há edições que se intitulam somente Guía del Lector del QUIJOTE e há outras, tais como: a Sudamericana (1961 e 1967); a Oxford University Press (1961), a Espasa- Calpe (1976 ,1978 e 1987) que se acrescenta o subtítulo Ensayo psicologico de QUIJOTE (acréscimo feito pelo autor). De uma edição para outra pode haver algumas mudanças no plano da superfície textual, mas não no plano do conteúdo.
} 
existiam parecidas ou derivadas, porém nunca haviam sido definidas, organizadas e estabelecidas de tal modo.

Essencialmente a obra é constituída por doze capítulos $^{24}$, além de algumas palavras dirigidas ao leitor e a introdução. Duas grandes etapas marcam o estudo de Madariaga: a primeira delas trata de analisar alguns dos problemas que sugere a atitude de Cervantes frente ao Quixote, pondo em juízo de valor Cervantes como crítico/criador e os livros de cavalaria. Na etapa posterior, o autor elege alguns temas de vertente psicológica $^{25}$ para destacar e explicar as personagens centrais da obra cervantina, os capítulos são respectivamente: "Cervantes y los libros de caballerías"; "Cervantes crítico"; "Cervantes creador"; "El dualismo del Quijote"; "Dorotea o la listeza", "Cardenio o la cobardia"; "El verdadero don Quijote"; "El inimigo interior de Don Quijote”; "El mito de Dulcinea”; "El verdadero Sancho”; “Era un cobarde Sancho Panza?"; "La fe de Sancho"; "La quijotización de Sancho" e "La sanchificación de Quijote"; "La cueva de Montesinos"; "La ascensión de Sancho"; “ El ocaso de Don Quijote" e, em 1967 o texto "Don Quijote, Europeo" completa a obra. Cabe destacar os capítulos especialmente reservados ao tema da inter(influência) das personagens, onde o autor tecera os principais referenciais acerca dos conceitos de sanchificação e de quixotização, os capítulos são: "La quijotización de Sancho"; "La sanchificación de Quijote"; "La ascensión de Sancho" e "El ocaso de Don Quijote".

A linguagem utilizada em Guía del Lector de QUIJOTE é sentimental, às vezes irônica e melancólica, também subjetiva frente ao texto quixotesco. A maneira eleita pelo autor é a espontânea, porém profunda no sentido de revelar os diferentes movimentos ocorridos no interior (como se refere o estudioso na alma) das personagens.

\footnotetext{
${ }^{24}$ Em março de 1967, pela "Revista de Occidente", publicou-se o ensaio "Don Quijote, Europeo" que será o último texto agregado ao Guía del Lector del QUIJOTE.

${ }^{25}$ Tais como: a fé, o medo, a covardia, a tristeza, a alegria, etc. Estados de ânimos comuns em seres humanos, os quais são interpretados nas personagens.
} 
O aspecto pouco científico que evidencia o fio tênue ao longo da exposição entre pessoa e personagem; entre narrador onisciente e autor e entre autor e a pessoa real chama atenção. Para Dotras Bravo isso se explica devido "El êxito de la psicología en estos primeros años del siglo XX conduce a Madariaga por caminos muy sugerentes.[...]" (2008, p.57).

A psicologia é a ciência que investiga os processos mentais e o comportamento humano. Essa ciência foi suporte teórico para o estudo de obras literárias como o Quixote, por intelectuais da época. Madariaga é visto pela crítica, segundo Dotras Bravo, como uma figura de destaque das análises psicológicas em personagens, uma vez que descreve o caráter das figuras literárias como se descrevesse em pessoas.

el exégeta se sitúa en un nível interpretativo. Entiende la obra creativa, entiende un mensaje $y$, dentro del mensaje, entiende a los personajes y los explica (describe) a partir de lo que ve, que asimila, a su vez, a la manera normal (con un específico conjunto de herramientas), con la que explica a los seres humanos de diferentes aspectos. $^{26}$

Com efeito, a psicologia parecia ser uma ferramenta teórica importante nos trabalhos de alguns autores, tais como: Madariaga, Unamuno e Dámaso Alonso que buscavam entender e resgatar aspectos da identidade nacional espanhola. Portanto, procurava-se nas grandes obras literárias nacionais a exegese do passado glorioso, a fim de compreender as instabilidades políticas, sociais e econômicas pelas quais passavam a nação na virada dos séculos XIX para o XX.

El interés por el personaje es paralelo a la preocupación por España, porque el uso de símbolos lleva, irremediablemente, a los personajes, elementos novelescos que facilmente encarnan dichos

\footnotetext{
${ }^{26}$ BRAVO DOTRAS. Alexia. Los trabajos Cervantinos de Salvador de Madariaga historia de una idea doble: sanchificación y quijotización. Alcalá de Henares. Centro de estúdios cervantinos. 2008, pgs.5960
} 
significados o, al menos, se acomodan a una particular visión de la historia política que les toco vivir. (DOTRAS BRAVO. 2008, p.57)

\section{PREÂMBULOS ACERCA DA SANCHIFICAÇÃO E QUIXOTIZAÇÃO}

"El dualismo del Quijote" corresponde ao segundo capítulo de Guía del lector del QUIJOTE, neste momento Madariaga não se concentra somente nas perspectivas crítica e criadora de Cervantes com respeito aos livros de cavalarias e sua própria obra, como faz no primeiro capítulo do ensaio, mas também examina o racional e o sentimental no Quixote. O racional se refere diretamente a tendência retórica e poética no estilo cervantino, enquanto o sentimental parece se conformar na espontaneidade criadora do gênio. A esse respeito acrescenta Alexia Dotras Bravo

Estos dos movimientos contrarios cristalizan además en los dos protagonistas, el realismo y la imaginación. Esta idea se ve todavia vaga en la concepción cervantina del personaje, ya que no los identifica con cada una de las corrientes, son más tendencias intrínsecas a Cervantes y su acción literária.(2008, p134)

Desse modo, Madariaga mostra de um lado a convivência desses valores no

Quixote e, por outro lado, afirma que a complexidade da obra cervantina reside no fato de nela conter "diversas corrientes de influencia que actuaban sobre Cervantes al tiempo en que escribió fluyen paralelamente" (MADARIAGA, p.65).

Os capítulos posteriores a "El dualismo del Quijote" cuidam de analisar as personagens dom Quixote e Sancho Pança pelo viés psicológico. Em que Madariaga evidenciou o interesse em explicar os conflitos, as incongruências, as mudanças no caráter dos protagonistas. O capítulo $\mathrm{V}$, "El verdadero don quijote", mostra cinco autênticas figuras literárias dom Quixote, Sancho, Don Juan, Hamlet y Fausto, embora o autor se dedique em realçar características relevantes para as três últimas personagens, tende a privilegiar categoricamente o par quixotesco. 
Dom Quixote e Sancho são figuras dotadas de grandes significados simbólicos, porque, segundo Madariaga, Cervantes consentiu a ambos a vitalidade humana, ou seja, amo/escudeiro se diferenciam de outras grandes figuras literárias pela complexidade compositiva de criativa imaginação e sensibilidade. Nesse sentido apresenta Madariaga, "Don Quijote y Sancho, la mies de ideaciones, interpretaciones y símbolos que a su favor se va formando continuamente se debe a la hondura de sus almas, a la riqueza del subsuelo humano [...]" (1987, p. 102). Com efeito, tal atitude, observa, permitiu à crítica literária do Quixote variedade de interpretações ora profundas e inspiradoras, ora "descabelladas". Enquadra-se no grupo das interpretações superficiais a de figuras antagônicas "inspiradas las más en un paralelismo que no está en el Quijote, y solo resulta de una antitesis falsa y superficial entre sus protagonistas." (MADARIAGA,1987, p.102).

Fica evidente a insatisfação do autor espanhol acerca da proposta antagonista para amo/escudeiro, entretanto Madariaga ao explicar e organizar os conceitos de sanchificação e quixotização acaba por incorrer no mesmo "erro". O autor parece não conseguir se desvencilhar dessa forte tendência incitada pelas interpretações românticas. Em seu trabalho Alexia Dotras Bravo chama atenção para uma carta ou "disertación", assim classificada, de Madariaga a Savj-López na qual o autor expressa o pesar das interpretações dos opostos psicológicos atribuído tradicionalmente às personagens esteja também presente nas análises dom Quixote e Sancho. Confessa Madariaga: 'pero que no puedo evitar los mismos errores'. (DOTRAS BRAVO, 2008, p.135) Em suma, o mais importante a se destacar neste momento é o desejo de Madariaga em se desprender das antigas interpretações, ou seja, de dom Quixote e Sancho como figuras antitéticas e, proporcionar por meio da análise psicológica dos protagonistas quixotescos um novo modelo de leitura. 
El grupo Quijote-Sancho aparece interpretado como un "par antagonista", cada uno de cuyos elementos queda convertido en cabeza de una serie de valores respectivamente opuestos.[...] Cabe opinar que por su misma riqueza espiritual, que estimula el pensamiento de los comentadores, las dos figuras cervantinas tienden a oscurecerse y desaparecer bajo la frondosidad intelectual que con vitalidad han ido alimentado.(MADARIAGA, 1987, p.103)

Como explica Anthony Close "la oposición entre sujeto y objeto, mente y naturaleza, espíritu y matéria, y las esferas de la libertad y la necesidad." foi confiado pelo movimento romântico ao longo de praticamente um século. ${ }^{27} \mathrm{~A}$ repulsa à maneira antagônica de apreender amo/escudeiro, haja vista a falta de profundidade dada aos distintos valores contidos nas personagens, permitiu ao autor de Guía del lector del QUIJOTE estabelecer novos parâmetros à dupla.

Madariaga se dedicou ao dualismo interior de dom Quixote em uma subclassificação no capítulo "El inimigo interior de Don Quijote", onde observa o real versus ideal existente no interior do cavaleiro. O conflito dom Quixote e Alonso Quijano revela características de aspectos psicológicos vinculados com a estrutura mental e comportamental comuns nos idealista, como explica Dotras Bravo. "Don Quijote como el mismo no es solamente un loco que se cree convertido en caballero andante, sino que conserva ciertas dudas acerca de su esencia"(2008,p.135). Segundo Madariaga se trata mais de um desvio estético proporcionado por Cervantes, quanto autor, do que expressamente um problema existente na alma da personagem. Ao proceder dessa forma, segundo Madariaga, Cervantes desvincula amo/escudeiro de estereótipos cujas realidades são óbvias e padronizadas.

Salvador de Madariaga mais uma vez rechaça no capítulo VI, "El verdadero Sancho", a tradição crítica literária por reduzir a trama cervantina a perspectivas

\footnotetext{
${ }^{27}$ CLOSE. Anthony. La concepción romântica de QUIJOTE.Barcelona. Crítica. 2005, p.60
} 
simplistas dos opostos, como trata $\operatorname{Close}^{28}$ o romantismo alemão que viu no Quixote uma obra de arte que antecipava e representava de forma direta a ideologia romântica, perde toda credibilidade do autor corunhês. Para tanto, isso se comprova por meio da visão crítica literária mais flexível frente ao par protagonista do Quixote. "La tradición superficial ha reducido su maravillosa trama psicológica a una línea melódica de elemental sencillez." (MADARIAGA.1987,p.122). Em linhas gerais, como mostra $\operatorname{Close}^{29}$ o caráter antagônico/conflitivo contido na natureza humana foi um dos traços marcantes na filosofia estética de alguns dos principais pensadores da escola romântica tais como: W. Schelegel, F.W.J. Shelling e o pós-romántico Hegel, os quais consideravam a arte de Cervantes como o produto biológico de condições culturais concretas, peculiares a uma época e uma nação, potencial representante do sentimento romântico.

El movimiento romántico definió el tema del Quijote de suerte que coincidia con una de las inquietudes esenciales de su metafísica, su estética y su arte: la oposición entre sujeto y objeto, mente y naturaleza, espíritu y matéria, y las esferas de la libertad y la necesidad. ${ }^{30}$

Este capítulo apresenta uma atitude decisiva de Madariaga para com os conceitos fomentados pela tradição romântica, frequentemente retomados pelo escritor. O autor afirma que a linha antitética dos protagonistas quixotescos "se resuelve en un delicado y complejo paralelismo, cuyo desarrollo es una de las maravillas de este libro genial'. (MADARIAGA, p.122) Madariaga explica que "Sancho es, en cierto modo, una trasposición de don Quijote en una clave distinta". Para Salvador de Madariaga don Quijote e Sancho Pança são figuras de valores paralelos, o autor destaca a importância do escudeiro para realçar e fortalecer a figura do amo e, também, do conjunto. Cabe

\footnotetext{
${ }^{28}$ CLOSE. Anthony. La concepción romântica del QUIJOTE. Barcelona. Crítica, 2005. p.55

${ }^{29}$ Idem. p.56

${ }^{30}$ Idem. p.60
} 
notar o significado de paralelo empregado, pois se torna o contraponto do significado de antagonismo, ou seja, o autor ao confirmar o paralelismo entre as duas figuras quixotescas confere importância e valor às constituições físicas, morais e intelectuais a cada uma das personagens. "Ambos son dotados de abundantes bienes de razón, intelectuales en don Quijote, empíricos en Sancho, y que en un momento pierden el equilíbrio de la vida y del pensamineto" (MADARIAGA, 1987,p.122)

A idéia máxima "de la transposición” não foi aprofundada, segundo Dotras Bravo, talvez por dois motivos principais: o primeiro motivo por ter formado o conceito já em momento adiantado do estudo, tornando difícil a inserção da teoria ou, o segundo motivo como apresenta a autora: "no le diese la importancia que tiene, justamente porque se separa de las líneas de investigación vigentes al comienzos del siglo XX". (DOTRAS BRAVO, 2008, p.137)

Neste momento de seu trabalho, Salvador de Madariaga aproxima as duas personagens por meio do lado positivo contido em cada uma, a inteligência. De um lado dom Quixote dotado de quesitos intelectuais e, de outro lado, Sancho beneficiado de intuição natural, saber inerente, nesse sentido, a personalidade de ambos é comum. Como observa Alexia Dotras Bravo o mesmo traço positivo que une e complementa amo/escudeiro os diferencia, ou seja, "la simpatía que les acerca se debe a que se han limado las diferencias que separaban a ambos personajes". (DOTRAS BRAVO, 2008, p.137)

Na subclassificação do capítulo VI, “EEra un cobarde Sancho Panza?”, Madariaga comenta com bastante afinco a suposta covardia de Sancho, a qual existe mais por palavras de dom Quixote, uma vez que a suposta falta de coragem do escudeiro, tantas vezes mencionada por dom Quixote, serve mais especificamente de contraponto para reforçar a bravura do amo. Com efeito, a "dúvida" acerca da falta de 
valentia/ânimo do escudeiro, segundo Madariaga, vai se dissolvendo ao longo dos capítulos, uma vez que a prudência e o sentido comum de Sancho se confundem com covardia. Desse modo, para o autor toda a vertente psicológica de Sancho se resume em:

Vigoroso y viril por temperamento, se encoleriza con relativa facilidad; prudente y cauto por sentido y experiencia, evita la lucha inútil y desigual; pueril y sencillo por ignorancia y naturaleza, tiembla ante lo desconocido y lo sobrenatural. En conjunto, digno hermano menor del caballero al que acompaña en la vida. (MADARAIGA,1987, p.129)

Em suma, em outra subclassificação do capítulo VI "La fe de Sancho", o autor mostra que a "fé" do escudeiro está intimamente ligada com dom Quixote pelo afeto e pelo benefício material, para tanto Sancho Pança crê no amo para poder crer no governo da ilha. Esse último aspecto, segundo o autor, deixa patente o caráter material de Sancho, sendo assim o "poder es para Sancho lo que la gloria es para don Quijote". (1987,p.135)

Nos capítulos seguintes o autor a partir de aspectos próprios dos seres humanos (alguns como: convivência, influência, aprendizado, alegria e frustração, objetos dos tratados psicológicos) confirma a intenção estética para os processos que desencadeiam as mudanças nos protagonistas. O primeiro a manifestar sintomas de mudanças é Sancho Pança, segundo o autor, já na primeira parte da obra, e, por se tratar de um processo evolutivo, se acentuará no Quixote de 1615. "El intelectual vasco quería significar el proceso de asimilación convergente entre los personajes que se produce, según él, ya en la I parte y se acentúa en la II.” (MARTÍN MORÁN,1992, p.4)

\section{QuiXotiZaÇÃo DE SANCHO E SANCHIFICAÇÃO DE DOM QUiXOTE}

Por fim a leitura dos capítulos que verifica a mutua influência das personagens protagonistas do Quixote: "La quijotización de Sancho" e "La sanchificación de don Quijote". Nestes capítulos depreende-se a versatilidade do autor em analisar a figura de 
Sancho Pança, diferentemente do ocorrido com a figura de dom Quixote. Isso se deve, porque Sancho é o primeiro a mostrar estreita e influente relação com o amo, desse modo por se tratar de um estereótipo elementar as alterações no caráter da personagem se manifestam claramente. O primeiro a apresentar sintomas de mudanças é Sancho Pança, segundo o autor, já na primeira parte da obra, e, por se referir a um processo evolutivo, as alterações no comportamento e no discurso se acentuarão ao longo da narrativa. Como trata Martín Morán no artigo, "Don Quijote esta sanchificado el desanchificador que lo requijotice...", Madariaga "quería significar el proceso de asimilación convergente entre los personajes que se produce, según él, ya en la I parte y se acentúa en la II.” (MORÁN,1992, p.4)

Com efeito, Salvador de Madariaga evidencia o novo estado do escudeiro discorrendo a respeito da conversa de Sancho com Tereza Pança, no capítulo V, da segunda parte, onde não somente diz do estilo cavalheiresco do aldeão, como também do discurso rebuscado. Embora o escudeiro apresente diferentes mudanças em suas características, Madariaga se concentra em apresentar as mudanças discursivas. "Mirad, Sancho- replicó Teresa -: después que o hicisteis miembro de caballero andante habláis de tan rodeada manera, que no hay quien os entienda."(D.Q.II, V, p.61). Para Madariaga "Estas palabras son la clave de la escena" (MADARIAGA, p.138).

Além de observar a postura de Sancho com sua esposa, afirmando que não se trata de imitação, mas de mudança na atitude do escudeiro com ele mesmo, tantas vezes vistas no amo. "Actitud paternal, protectora, educadora, ya conciliante y paciente, ya colérica y dominante”. (MADARIAGA, p.138) Madariaga atenta para as variações no âmbito interno e externo da personagem.

As alterações externas decorrem da observação e admiração das atitudes (paternal, educadora, paciente e colérica) do amo, e se refletem no discurso e no 
comportamento do escudeiro. "Mas no para en sus dichos e ideas la imitación que hace de su señor; antes bien, toda su actitud para con su mujer es esta escena trasunto de la actitud para con él mismo" (MADARIAGA, 1987, p.138) Já as mudanças internas, não menos profundas, estão na assimilação gradual do universo da fantasia imposto por dom Quixote, tal como a ilha materializa o poder, enquanto que, para dom Quixote, Dulcinea personifica a glória. Dotras Bravo explica que

el diferente tipo de ambición, más material en Sancho y más espiritual en el hidalgo, se aproxima, de manera que lo codiciado se convierte primero en vanidad, estadio intermedio fomentado por la fama, y más tarde en poder. Aún así, siguen siendo motivaciones concretas, poder o fama al alcance de la mano, pero eso no excluye que el escudero en su lenguaje se iguale a su amo, utilizando plurales inclusivos y enumeraciones en las que Sancho es el primer elemento. 31

Ainda traçando aspectos do fiel escudeiro, Madariaga acrescenta no pacote das mudanças internas a vaidade e gloria despertadas pelo relato de Sansón Carrasco acerca da publicação da primeira parte do Quixote, à possibilidade de ser conhecido pelo mundo inflama Sancho. "La escena en que Sansón Carrasco comenta con el escudero y su amo la historia del ingenioso hidalgo que anda impresa, constituye un momento culminante en la vida de Sancho". (MADARIAGA,1987, p.140). A nova situação eleva Sancho na relação com o amo e confere certo grau de importância e para o seu crescimento. "ya en presencia de un Sancho crecido, un Sancho que se siente en cierto modo al nível de su señor" (MADARIAGA, 1987, pgs. 142-143)

As idéias apresentadas continuam no capítulo X, "La ascención de Sancho", onde o autor parte da afirmação na qual o escudeiro, em certa medida, passa para segundo plano a ambição material, dando lugar para a fama, ou seja, torna-se

\footnotetext{
${ }^{31}$ BRAVO DOTRAS. Alexia. Los trabajos Cervantinos de Salvador de Madariaga historia de uma idea doble: sanchificación y quijotización. Alcalá de Henares. Centro de estúdios cervantinos. 2008,p. 139
} 
preponderante o fato de ser conhecido por meio da letra impressa. Dando continuidade, Madariaga afirma que a ascensão de Sancho está no fato da personagem estar "vigorizado y(a sus propios ojos) esalzado" (p.171).

A subida de Sancho reside no fato de se valorizar e de se fazer conhecido, com efeito, a ascensão do fiel escudeiro coincide com o declínio de dom Quixote rumo à desilusão. A partir dos movimentos ocorridos nos perfis ${ }^{32}$ de dom Quixote e Sancho provocam o ponto de convergência entre ambos e como ratifica Dotras Bravo, Madariaga inicia a relação de (inter)influência das personagens. Este pensamento foi o passado na crítica posteriormente e é o que se entende por sanchificação e quixotização.

Esta afirmación, que es la que ha pasado posteriormente a la crítica y que es como se entiende en la actualidad la teoria de sanchificación y quijotización, no coincide con la explicación del paralelismo entre los personajes, ya que la dirección es distinta, las paralelas no coinciden en el espacio, pero si en el tiempo, mientras que las líneas que se influyen mutuamente, se cruzan en el espacio y en el tiempo, por lo que el contacto es mayor. ${ }^{33}$

Se Sancho foi o primeiro a mostrar mudanças em grande parte positivas para seu crescimento, Dom Quixote, ao contrário, está em constante declínio, aproximandose gradualmente do nível do escudeiro, como é descrito no capítulo VIII, "La Sanchificación de don Quijote”. Os efusivos desenganos favorecem o“ empobrecimento espiritual del héroe, que se manifesta en la pasividad de su ánimo al comienzo de la

\footnotetext{
${ }^{32}$ A autora Alexia Dotras Bravo chama intelectual ( relativo ao intelecto, ao entendimento, à atividade de reflexão(Dicionário Larousse)) o crescimento de Sancho "Esta subida intelectual de Sancho coincide con el descencio del hidalgo." (p.139-140) Enquanto, denomino perfil (traços na característica do escudeiro) o crescimento de Sancho ( a" fé"em si próprio). Como Madariaga aponta, o crescimento consiste no conhecimento e valor dado a personagem por conhecimento dela mesma. Para Madariaga "[...] las relaciones entre ambos [...] de influencia, ya de Don Quijote sobre Sancho, ya de Sancho sobre Don Quijote, ya a nivel. (p.171)

${ }^{33}$ BRAVO DOTRAS. Alexia. Los trabajos Cervantinos de Salvador de Madariaga historia de uma idea doble: sanchificación y quijotización. Alcalá de Henares. Centro de estúdios cervantinos. 2008, p.140
} 
segunda parte."34 Para Madariaga o processo de declínio nos ideais cavalheirescos converge para a retomada da realidade.

Por su parte, Don Quijote se acerca al nível del escudero porque no se deja llevar por ese exacerbado amor a la caballería andante y se muestra pasivo y ajeno a la acción que ahora domina a Sancho. Esta relación en el genio se acompaña de la tranquilidad con que pagas ventas o se deja corregir por Sancho o no defiende la belleza de la sin par Dulcinea hasta la saciedad y la exigencia extrema. $^{35}$

Como faz ao tratar da quixotização de Sancho, Madariaga discorre a respeito da sanchificação de dom Quixote a partir de uma linguagem subjetiva fundamentada por passagens da obra, as quais contribuem para a confirmação das análises. Haja vista que não se pretende mencionar todas as passagens analisadas pelo autor, mas evidenciar o episódio da "Cueva de Montesinos" momento especial para o autor.

Na análise de Dotras Bravo acerca da sanchificação de dom Quixote, a escritora observa dois pontos muito interessantes nos estudos psicológicos de Guía del Lector del QUIJOTE. O primeiro ponto se refere ao tipo de patologia psiquiátrica, a depressão, a fim de explicar a influência de Sancho no amo, o enfraquecimento moral, como se refere Madariaga, já no final da primeira parte, prognóstico do empobrecimento da ideologia cavaleiresca ao longo da segunda parte, ou seja, dom Quixote é passivo, em grande parte, frente às atitudes do escudeiro. As mudanças externas do cavaleiro consistem na aceitação das exigências materiais e na resignação das viagens com dinheiro, fazendo com que dom Quixote da segunda parte seja mais passivo e tolerante em relação ao da primeira parte, tão decidido e audacioso. A isso se acrescentam os desenganos que surgem, incisivamente, a cada aventura, os quais são vetores, como foi dito, do processo

\footnotetext{
${ }^{34}$ MADARIAGA Y ROJO. Salvador. Guía del Lector del QUIJOTE.1987, p.150

${ }^{35}$ BRAVO DOTRAS. Alexia. Los trabajos Cervantinos de Salvador de Madariaga historia de uma idea doble: sanchificación y quijotización. Alcalá de Henares. Centro de estúdios cervantinos. 2008,p.140
} 
de retomada à realidade. Já se verifica no capítulo $\mathrm{XX}$, da primeira parte, certa resignação do cavaleiro em favor dos acontecimentos.

Desesperábase con esto don Quijote, y, por más que ponía las piernas al caballo, menos le podia mover; y, sin caer en la cuenta de la ligadura, tuvo por bien de sosegarse y esperar, o a que amaneciese, o a que Rocinante se menease, creyendo, sin duda, que aquello venía de otra parte que de la industria de Sancho" (D.Q.I, XX, p.248)

O capítulo "El ocaso de Don Quijote”, como ocorreu na análise da quixotização de Sancho, retoma conceitos que significam sanchificar. O ensaísta, de modo especial, observa no encantamento de Dulcinea o motivo real para o decaimento definitivo do herói e triunfo do escudeiro, além de configurar a sanchificação de dom Quixote como: ausência de ânimo, humor melancólico, mudanças de estilo e no registro lingüístico.

$\mathrm{Y}$ es que en el mismo momento en que el caballero se esfuerza por conservar su superioridad moral sobre Sancho, Cervantes ha sabido entremezclar en su actitud y discurso pruebas claras de la influencia que Sancho había conseguido ejercer sobre él, no ya en la sustancia de algunos de los consejos, sino hasta en el lenguaje y en la actitud de Don Quijote para con la riqueza de refranes de que dispone Sancho.(MADARIAGA, 1987,p.187)

O referencial linguístico de dom Quixote é a maior marca de influência para o ensaísta. Ao longo do capítulo se verifica uma série de passagens do Quixote, nas quais demonstram o cavaleiro menos idealista e mais sanchificado.

Em resumo, este capítulo de um lado buscou projetar aspectos dos ideais filosóficos emergentes, possíveis ainda de serem identificados em estudos críticos sobre os protagonistas do Quixote, até hoje. Isso é possível afirmar a partir do estudo feito de uma pequena parcela de artigos e ensaios críticos onde ao longo dos dois capítulos seguintes se aspira mostrar a transcendência da proposta de Madariaga na crítica 
cervantina ao longo do século passado. Por outro lado, o capítulo também procurou adentrar em certos aspectos da vida e da obra de Salvador de Madariaga y Rojo. 


\section{CAPÍTULO II - Trabalhos críticos: a repercussão convergente da idéia de Madariaga}

\section{ALGUMAS IDÉIAS PRELIMINARES}

Antes de adentrar na exposição dos trabalhos críticos é interessante expressar algumas opiniões que, não só corroboram certos aspectos do que já foi dito, mas também contribuem para melhor organizar a exposição proposta para este capítulo.

Salvador de Madariaga por intermédio de um único ensaio, haja vista que não se tem notícia de nenhum trabalho seu que versasse sobre a relação entre dom Quixote e Sancho Pança, fomentou na crítica do século passado grande interesse entorno ao tema. Como confirma Alexia Dotras Bravo ao longo de seu estudo, a sanchificação de dom Quixote e a quixotização de Sancho se mostrou, por meio das análises críticas, assunto bastante conhecido.

Cabe notar no ensaio Guía del Lector del QUIJOTE a presença da dualidade entre o passado e o presente que se conforma quando na estrutura do texto o autor deixa aparecer de uma leitura idealizada na estética romântica ${ }^{36}$, mas se mostra partidário de um novo modelo de leitura entorno das personagens do Quixote. Dito de outra maneira, o modo como Madariaga se aproxima e interpreta as mudanças de dom Quixote e Sancho Pança, em tese, está influenciado por dois tipos de pensamentos com respeito à obra literária: um antigo e outro moderno. $\mathrm{O}$ ensaio acaba trazendo para o seu próprio interior, tão refutados,- pelo autor-, como os traços da postura idealista e simbólica frente ao Quixote. A fim de acrescentar, os critérios subjetivos, de leitura e interpretação

\footnotetext{
${ }^{36}$ Os traços referidos são: de caráter simbólico, subjetivo, idealista e antitético.
} 
do tipo acomodatício ${ }^{37}$, como conceitua Anthony Close, quando se busca acomodar o sentido do romance à mentalidade do leitor contemporâneo, contribui para os momentos de anacronismo presenciados na leitura da obra de Madariaga.

Outro ponto a ser observado diz respeito à repercussão dos conceitos de Salvador de Madariaga para as mudanças na relação amo/escudeiro que se propagaram até os tempos atuais. Alexia Dotras Bravo, ao longo de seu trabalho, diz que o êxito do ensaísta se explica mais por meio da intensa vida intelectual do escritor, a qual favoreceu seu reconhecimento dentro e fora da Espanha, reservando a Madariaga papel importante em estudos críticos posteriores. Comentado isso, a autora afirma que o ensaísta "se revela como una figura mucho más compleja de lo que un ensayo exitoso, si, pero poco leído, bastante citado y mucho más influyente de lo que parece" (DOTRAS BRAVO, p.240) Embora Madariaga tenha ao longo de um período ocupado lugar em trabalhos de renomados estudiosos desde Ángel Sánchez Rivero ${ }^{38}$ (1927) até artigos atuais como o de José Montero Reguera ${ }^{39}$ (2006), não garantiu a sua proposta atenção além da série de citações nos trabalhos críticos de renomados autores.

APROXIMAÇÕES ACERCA DA SANCHIFICAÇÃO E DA QUIXOTIZAÇÃO DE SALVADOR DE MADARIAGA

Nos estudos críticos a respeito das personagens protagonistas do Quixote posteriores a Guía del Lector del QUIJOTE, notar-se-á ora direta, ora indiretamente a difusão e importância dos conceitos propostos por Salvador de Madariaga. Foi possível

\footnotetext{
${ }^{37}$ CLOSE. Anthony; DE LA GRANJA. Agustín; POU. Pablo Jauralde Pou; JOHNSON. Carroll B.; LERNER. Isaías; MONTERO REGUERA. José; REDONDO. Augustín; REY HAZAS. Antonio; RIVERS. Elías L.; SÁNCHEZ. Alberto; SEVILLA ARROYO. Florencio. "La crítica del Quijote desde 1925 hasta ahora". CERVANTES. Centro de Estudios Cervantinos, 1995.

${ }^{38}$ SANCHEZ RIVERO. A. "Las ventas del QUIJOTE”. Revista de Occidente, XVII, 1927.

${ }^{39}$ VIEIRA. Maria Augusta da Costa. (org.). Dom Quixote: a letra e os caminhos. São Paulo. EDUSP, 2006. "Miguel de Cervantes e o Quixote: de como surge o romance", pgs 17-43
} 
a partir do estudo de uma pequena parcela dos renomados trabalhos sobre o tema, separar os cenários interpretativos que foram se estabelecendo ao longo dos anos, começando pelos pontos de vista convergentes, passando pelos detratores da idéia até chegar às análises críticas contemporâneas onde se depreende estudos mais guarnecidos de critérios teóricos literários afastados das referências analíticas historicistas do principio do século. Salvador de Madariaga, assim como outros acadêmicos de começo de século traziam na maneira de abordar a obra literária resquícios das fortes tendências do século XIX, como explica Anthony Close

Hasta 1925, y sobre todo en el siglo XIX, las figuras destacadas del movimiento acomodatício (los románticos alemanes, Benjumea, la generación del 98) hablaban desde fuera del círculo del cervantismo académico, y abogaban por el estúdio "filosófico" del Quijote, es decir, un tipo de aproximación que penetra más allá de la superfície retórica e histórica del texto ${ }^{40}$

Percebeu-se ao longo das leituras aspectos mais recorrentes acerca da idéia de Madariaga e outros aspectos já pouco aprofundados, ou seja, uma parte dos autores privilegiara os conceitos de evolução em decorrência da convivência, alguns se detiveram na aproximação e transformação de características dos protagonistas, já outros se fundamentaram no conceito não desenvolvido pelo autor de que Sancho é, de certo modo, uma transposição de dom Quixote en clave distinta,ou seja,alguns estudiosos se referem a amo e escudeiro como um bifronte dom Quixote e Sancho. No entanto, nenhum dos trabalhos analisados contemplou os conceitos de sanchificação e de quixotização em sentido amplo. Há ainda aqueles que se dedicaram mais em mostrar uma personagem, isto é, dando atenção às possíveis transformações em dom Quixote ou Sancho, já outros buscaram o equilíbrio, isto é, trataram da evolução e mudança no par protagonista do Quixote. Disso tudo, o indispensável é a consonância das propostas,

\footnotetext{
${ }^{40}$ CLOSE,Anthony. "La crítica del Quijote desde 1925 hasta ahora" em Cervantes, 1995, p.312
} 
pois todas se revelam parte do processo de construção do significado de sanchificação e quixotização.

O artigo de José Manuel Martín Morán, "Don Quijote está sanchificado; el dessanchificador que lo re-quijotice", de 1992, segundo Dotras Bravo é o único trabalho crítico de extensão até a atualidade fundamentado em critérios científicos entorno da problemática de Madariaga. A tese do autor foi de fato o que impulsionou esta dissertação, pois a partir de seu trabalho tornou-se possível traçar a linha cronológica (autor/data) dos textos críticos, além disso, por meio do artigo foi possível confirmar a necessidade de um trabalho como este, de balanço crítico. Cabe explicar que a proposta de José Manuel Martín Morán formará parte do capítulo posterior onde caberão as perspectivas em relação à questão.

Alguns críticos, dentro dos estudos cervantinos, seguiram a linha de Madariaga, convergindo para a evolução e simbiose de amo/escudeiro. Como afirma Martín Morán, os primeiros trabalhos foram de A. Sánchez Rivero, "Las ventas del Quijote" e de Dámaso Alonso, "Sancho-Quijote; Sancho-Sancho". Já os textos seguintes transcenderam a opinião de Madariaga, e cada um acabou encontrando seu modo de entender as relações entre as duas personagens. A seguir, o que pretende é apresentar um cenário crítico em que figuram alguns estudos críticos importantes que, em alguma medida dialogam com o trabalho de Madariaga. Nesse caso, serão aboradados os seguintes trabalhos: de Pedro Salinas "Lo que le debemos a Don Quijote"; de Eric Auerbach em Mimesis:a representação da realidade no mundo ocidental; de Luis Rosales em Cervantes y la Libertad; de J. B. Avalle-Arce e E. C. Riley, "Don Quijote" em Suma Cervantina; de Maurice Molho "Raiz folklórica de Sancho Panza" em Cervantes: raíces folklóricas; de Gonzalo Torrente Ballester, El QUIJOTE como Juego; 
de Carlos Fuentes, Cervantes o la crítica de la lectura e de Javier Salazar Rincón,’El personaje de Sancho Panza y los lectores del siglo XVII”.

II. 1- CEnÁrio CRÍtico dos ENFOQUes CORRESPONDENTES À EVOluÇão E SIMBIOSE DE DOM QUIXOTE E SANCHO PANÇA

ÁNGEL SÁNCHEZ RIVERO $-1927^{41}$

O artigo "Las ventas del Quijote" ${ }^{42}$ de A. Sánchez Rivero ${ }^{43}$, trabalho 1927, segundo bibliografia de José Manuel Martín Morán, consta da Revista de Occidente (XVII), do ano de 1927. O intelectual foi o primeiro a redizer, em ano tão próximo ao da primeira publicação de Guía del Lector de QUIJOTE, a teoria da realidade única(característica dual) para amo/escudeiro apontado por Salvador de Madariaga. José Manuel Martín Morán afirma que “A. Sánchez Rivero quien, en su polémica de la Revista de Occidente con Américo Castro, llega a afirmar que el personaje del Quijote es en realidad único, un bifronte Don Quijote-Sancho [...]",44

A fim de contribuir com a exposição, Alexia Dotras Bravo verifica no artigo de Rivero o estilo argumentativo que se configura pelo tom erudito e retórico. Além disso, a autora considera que Sánchez Rivero, como Salvador de Madariaga, desprestigia o mero entendimento de dom Quixote como pobre fidalgo e louco, para isso Rivero considera que Cervantes não poderia construir obra extensa protagonizada por um louco, porque não seria possível estabelecer a identificação a todo o momento entre

\footnotetext{
${ }^{41}$ A fim de melhor contribuir com a ordem de leitura: os trabalhos serão apresentados, indicando em primeiro lugar nome do autor e em seguida a data da publicação do respectivo estudo.

${ }^{42}$ A apresentação deste artigo fatalmente dar-se-á por meio da (re) leitura das análises feitas pelos autores José Manuel Martín Morán e Alexia Dotras Bravo, já que não foi possível ter acesso ao texto original. Tendo em vista sua importância para a melhor organização cronológica dos textos, foi importante, ainda que proveniente de fontes secundárias apresentar sucintamente a proposta de Sánchez Rivero, a fim de mostrar o caráter convergente/similar de sua proposta. Já com relação ao artigo "Contestación", que se segue, foi possível fazer a leitura direta.

43 Data de nascimento e morte de Ángel Sánchez Rivero (1888 - 1930). Interessante notar a data, pois a publicação deste artigo foi nos últimos anos de sua vida.

${ }^{44}$ MARTÍN MORÁN. José Manuel. "Don Quijote está sanchificado; el des-sanchificador que lo requijotice..." 1992, p. 5 (Nota de rodapé 19)
} 
texto e leitor. Bravo descreve que somente no final do artigo aparece a figura de Sancho Pança como elemento elevado à categoria espiritual de uma caricatura cômica, entre o mundo imaginário do herói e o do universo real dos leitores. Com o objetivo de elucidar, Dotras afirma "ese fondo es Sancho Panza, el hallazgo verdaderamente fértil de la mente creadora de Cervantes, ya que es producto de la creación, del universo ficcional cervantino". 45

A respeito da polêmica entre Sánchez Rivero e Américo Castro, referida por Martín Morán, cabe notar a opinião de Dotras Bravo que entende ser interessante a afirmação de Rivero acerca das personagens, pois para o autor se trata de uma relação amo/escudeiro como um conjunto harmonioso, onde abunda valores únicos, ao mesmo tempo compartilhados. Em suma, a autora diz que Rivero não concorda com "la antinomia realidad-ilusión, realismo-materialismo y, por conseguinte, Don QuijoteSancho". 46

“Contestación” - 1927

"Contestación” ${ }^{47}$ é um segundo artigo de Sánchez Rivero, publicado na Revista de Occidente, em 1927, o qual está intimamente relacionado com “ Las ventas del Quijote". A diferença entre um trabalho e outro, respectivamente, reside na intenção de Rivero por um lado em responder às observações sublinhadas por Américo Castro com respeito ao seu artigo, mas, por outro lado, polemizar com respeito a alguns pontos da perspectiva de Castro acerca do Quixote e de Cervantes. A obra de Castro em questão é El pensamiento de Cervantes e, no caso Rivero organiza seu trabalho a partir de

\footnotetext{
${ }^{45}$ DOTRAS BRAVO, Alexia. BRAVO DOTRAS. Alexia. Los trabajos cervantinos de Salvador de Madariaga Historia de una idea doble: sanchificación y quijotización. Alcalá de Henares (Madri), Centro de Estudios Cervantinos, 2008, p.247

${ }^{46}$ Idem, 2008, p. 247

${ }^{47} \mathrm{O}$ acesso ao artigo "Contestación" só foi possível tão recentemente. Por se tratar de um trabalho que ilumina "Las ventas del Quijote" se fez interessante apresentá-lo.
} 
respostas acerca de "Las ventas del QUIJOTE" e, de indagações com respeito ao estilo de pensamento fomentado em El pensamiento de Cervantes.

Nas primeiras linhas do artigo Rivero apresenta para seus receptores o público em geral e Américo Castro, de modo especial, as posturas divergentes e convergentes para algumas idéias pontuadas por Castro. "Creo que, en definitiva, quedaremos conformes, salvo alguna diferencia en apreciaciones parciales, desde luego, accesorias." (Sánchez Rivero, Angel. 1927, p.291)

Em meio à polêmica com Américo Castro, Rivero se mostra partidário de duas idéias muito parecidas com as opiniões fundamentadas em Guía del Lector del QUIJOTE, a respeito de Cervantes e o Quixote. Os dois momentos que se pretende apresentar são: a unidade vital da obra, por consequencia das personagens, e a discussão sobre à personalidade criadora de Cervantes, que estão aqui para ilustrar e corroborar as opiniões anteriormente comentadas.

Para Rivero, a estrutura do Quixote se constitui com base em uma perspectiva criadora, humana, não necessariamente arquitetônica cujo perfil é seguir padrões estabelecidos pelas preceptivas poéticas dos séculos XVI e XVII. O Quixote, segundo o autor, é uma invenção organizada, ou seja, Miguel de Cervantes tinha consciência da realidade artística de sua época, conhecia os objetivos críticos, a dinâmica a ser tomada, mas não se prendeu a nenhum dos modelos estabelecidos. Cervantes foi um escritor inovador, porque havia nele certa consciência criadora. Como explica Sánchez Rivero:

Esta conciencia no necesitaba ser crítica, es decir, esquematizada en conceptos. Era una conciencia clara de lo concreto con esa concreción que sólo en el acto creativo se da y que el pensamiento reflejo jamás puede alcanzar, aunque se esfuerce sin descanso en llegar a ella. (SANCHEZ RIVERO, 1927, p.298) 
Como Madariaga, Rivero observa a audácia e espontaneidade criadora de Cervantes inerentes ao autor. Neste universo criativo, segundo Rivero, as personagens dom Quixote e Sancho vão sendo formadas ao longo da narrativa, segundo as circunstancias. Amo/escudeiro, para Rivero, não devem ser vistos como figuras antagônicas: realidade e ilusão, no entanto entendidas como figuras provenientes da unidade criadora.

la unidad del Quijote es unidad vital, la unidad del organismo en su crecimiento, no en su estructura momentánea; la unidad de un devenir, no la unidad de un ser. Ahora bien, en un ser, todas las partes se dan simultáneas, y, por tanto, su integridad es condición ineludible mientras que en un devenir las partes, si de partes puede hablarse en este caso, van apareciendo en la contigencia de un destino. (SÁNCHEZ RIVERO, 1927, p.294)

Em suma, "Contestación” apresenta idéias, tais como: criação, espontaneidade, dinamismo narrativo. Além disso, rompe com o modelo interpretativo antitético para o par quixotesco.

\section{ERICH AUERBACH - 1945}

Em Mimesis: a representação da realidade na literatura ocidental publicada em 1945 por Erich Auerbach, encontra-se um capítulo dedicado à obra de Cervantes intitulado "A Dulcinéia encantada". A obra se destaca pela densidade da análise do estilo de obras canônicas européias e, entre elas, o Quixote. Para sua análise, Erich Auerbach escolhe o capítulo $\mathrm{X}$, da segunda parte, que, por sua vez, traz à tona o embate entre realidade e ilusão no universo criado por dom Quixote. Além disso, a perspectiva analítica do autor se pauta pela leitura burlesca do texto cervantino, ao afirmar que Cervantes privilegiara fundamentalmente o riso na criação de sua obra, sendo que o cômico se estabelece na estrutura narrativa da própria obra por meio do jogo entre as diferentes perspectivas das personagens. 
O capítulo X trata do encantamento de Dulcinea, onde o autor observou a partir do recorte do diálogo entre dom Quixote e Sancho e as três labradoras a dinâmica do real representado no universo cervantino. Antes, cabe notar que para o autor alemão a representação da realidade na obra literária está em consonância com o espírito humano de quando foi criada e neste âmbito de afortunada percepção a relação entre amo e escudeiro foi confiada.

Erich Auerbach utiliza na maior parte de sua análise o método de interpretação de texto para mostrar a complexidade da criação cervantina, em especial, na relação dom Quixote e Sancho na segunda parte da obra, quando o escudeiro parece ter se inteirado totalmente do universo imaginário do amo a ponto de enganá-lo. $O$ encantamento de Dulcinea favorece outra perspectiva para as personagens protagonistas, porque pela primeira vez ocorre inversão nos papéis e superação do esperado no comportamento de amo/escudeiro.

Em meio ao contexto narrativo, o autor ora eleva Sancho Pança que apresenta por meio do discurso o aprendido de dom Quixote, ora chama atenção para dom Quixote que também se desenvolve e aprende a ser mais bondoso, sábio e mais flexível mesmo em meio a sua loucura, que consiste na idéia fixa a respeito dos ideais cavaleirescos. Já em outros momentos Erich Auerbach eleva amo/escudeiro ao mesmo patamar de atenção. A inversão de papéis ocorre efetivamente pela primeira vez neste capítulo em decorrência já do processo de aprendizado iniciado desde a primeira saída de amo/escudeiro. Para Auerbach a relação entre as personagens se configura em uma atmosfera do riso que se estabelece desde a perspectiva de um pensado jogo de estilos, em que Sancho brinca com a loucura do amo. Explica o autor: "Sancho improvisa uma cena de romance, enquanto que a capacidade de Dom Quixote de transformar os 
acontecimentos segundo a sua ilusão falha diante da crua vulgaridade do aspecto das lavradoras." 48

Dom Quixote e Sancho Pança são paralelamente observados pelo o autor, no entanto constata-se na figura do escudeiro em se tratando de aprendizado e evolução mais atenção e destaque. Auerbach se centra na análise da obra, na realidade criada e na realidade quotidiana, destacando as saídas encontradas pelo cavaleiro para se locomover entre elas sem antes do último capítulo se desvencilhar da idéia fixa. Segundo o autor, "na sua própria idéia fixa, encontra uma saída que o livra tanto do desespero quanto da cura: Dulcinéia está encantada." 49 Erich Auerbach preocupa-se com os estilos lingüísticos da personagem Sancho Pança, ou seja, com as manifestações discursivas apresentadas no capítulo analisado como decorrência do processo de aprendizado com o amo.

É maravilhosamente bela. Acabamos de dizer quão destramente e com quanta graça Sancho sabe utilizar o estilo dos romances de cavalaria, que aprendeu do seu senhor; aqui fica evidente de que calibre era o seu mestre. ${ }^{50}$

Em tese, de um lado a proposta mimética se configura na relação de Cervantes com o estilo retórico cortês de tradição antiga proferido diversas vezes por dom Quixote e aprendido por Sancho Pança a fim de favorecer o tom de brincadeira, em paralelo com os acontecimentos que dizem respeito à realidade vivida são constantemente contrastados, proporcionando o elo com o plano real e fictício. Por outro lado, o tom jocoso é a melhor forma de interpretação para a cena do encantamento que trata da defesa do ideal encarnado e não da luta contra a realidade, isto é, dom Quixote aceita o

\footnotetext{
${ }^{48}$ AUERBACH, Erich. "La Dulcineia encantada", Mimesis. La representación de la realidad en la literatura occidental, México: Fondo de Cultura Económica, 1950, p.303

${ }^{49}$ AUERBACH, Erich. "La Dulcineia encantada", Mimesis. La representación de la realidad en la literatura occidental, México: Fondo de Cultura Económica, 1950. p.304

${ }^{50}$ Idem, 1950. p.304
} 
jogo proposto e a idéia fixa ocupa lugar, resultando na falta de sentido e em uma cômica confusão de valores. Tudo isso a fim de mostrar a perspectiva predominantemente cômica do texto cervantino, por conseguinte da relação entre as personagens.

Em resumo, o autor termina afirmando que todo requinte e alegria da obra se configura na relação amo/escudeiro que unidos em amor e fidelidade retratam aspectos sem julgamentos prévios de um tempo e de uma sociedade. Sendo assim, a ordem da realidade consiste em um jogo de perspectivas onde todas as visões são consideradas, onde o que se julga é o trabalho artístico do autor quanto à obra literária, nada é condenado.

\section{LUIS ROSALES - 1959-1960}

Em Cervantes y la Libertad de Luis Rosales encontra-se uma série de estudos sobre a obra de Cervantes mas, em especial, sobre o Quixote. O estudo de Rosales fezse relevante para este levantamento, uma vez que boa parte dos textos pesquisados para este trabalho, de maneira direta ou indireta, menciona o nome desse autor. Interessante observar que ao longo do estudo se notou que Rosales se refere, de maneira circunstancial, a Salvador de Madariaga. Para melhor informar, especialmente ao que se refere ao tema da quixotização de Sancho e sanchificação de dom Quixote, o autor compartilha da mesma leitura proposta por Madariaga, ou seja, verifica a simbiose dos protagonistas.

Luis Rosales no capítulo IV, intitulado "La comedia de la felicidad" dialoga com La comedia de la Felicidad de Nicolás Evreinov. Depreende-se neste capítulo em especial a postura de Rosales acerca da quixotização de Sancho Pança. Dito isso, em linhas gerais La comedia de la Felicidad se refere a uma (meta)comédia que

\footnotetext{
${ }^{51}$ A primeira edição dos tomos (I e II) é entre os anos de 1959-1960. O analisado para o trabalho se trata da segunda edição de 1985. Como é interessante traçar o perfil cronológico do tema cabe marcar sempre os primeiros anos da publicação da obra.
} 
proporciona às personagens experienciais pessoais que favorecem a cada uma o sonho desejado. Passado isso, as personagens conseguem resolver seus problemas e examinam seus valores, identificando-os como bons ou maus. Este breve relato serve para conformar o episódio dos duques, diz o autor “[...] la comedia inventada por los Duques, la comedia de la felicidad [...]"52, em especial para elucidar o motivo da mudança no modo de pensar de Sancho Pança.

Dando continuidade, na subclassificação do capítulo "La nueva valoración de Sancho”, Luis Rosales chama atenção para a elevação de Sancho como figura principal, como protagonista em mesmo grau de importância de dom Quixote. O autor se vale da posição interpretativa frente ao texto, comparando um trecho com o outro e, desse modo, discorre acerca da elevação de Sancho Pança. Além disso, se concentra na segunda parte do Quixote no episódio do castelo dos duques, em especial, no governo da ilha Barataria, pois se refere a momentos nos quais escudeiro/amo estão em permanente evidencia. Para Rosales o modo de lidar de Sancho com as vertentes do real e da ficção no plano narrativo corroboram para o amadurecimento de sua personalidade, acarretando a transformação de Sancho.

Mais adiante, na quarta parte da obra, no item "La nueva relación de Don Quijote y Sancho", Rosales reforça a opinião acerca da quixotização de Sancho. Retoma ora implícito, ora explicito no plano discursivo as teses de Madariaga acerca da influência entre as personagens. Cabe mencionar que segundo Luis Rosales o processo de simbiose acorre em ambos os personagens, dessa forma dom Quixote se sanchifica quando deixa de confundir a perspectiva vivida com a inventada, ou seja, quando se desprende da idéia fixa; dom Quixote amadurece, se humaniza de modo gradual, por um processo iniciado na primeira parte da obra e conclusivo na segunda parte. A partir daí,

\footnotetext{
${ }^{52}$ ROSALES. Luis. Cervantes y la Libertad. Volume I. Madrid, Ed. Cultura Hispanica, 2 ed.,p. 487
} 
diz Rosales "Ahora bien esta transformación obedece a una ley de crecimiento, y es necesaria e ineludible, como es ineludible el cambio de carácter cuando se llega a la madurez.",53

Para concluir, o capítulo $\mathrm{X}$, da segunda parte, que trata do encantamento de Dulcinea é considerado como ocasião culminante não somente para as mudanças no caráter de dom Quixote e Sancho Pança, mas também para a relação entre o par quixotesco, que segundo o autor, se converteu em relação de companheirismo. A respeito de tudo que foi dito, acrescenta Alexia Dotras Bravo, em especial, a respeito de dom Quixote

El cambio de caráter del personaje, subrayado por vários acontecimentos que lo corroboran una y otra vez, demuestran la consistencia de esa metamorfosis para Rosales y lo acercan a la doctrina madariaguesca de la evolución gradual de los personajes. El primero de los actos es la ausência de confusión de la realidad ("visión objetiva y visión alucinada" en palabras del académico) e incluso intercambio de la percepción de las cosas, debido a que Sancho si ve los elementos a través del prisma del encantaminento. ${ }^{54}$

PEDRO SALINAS - 1961

Pedro Salinas seguindo o conceito de dualidade ou bifronte dom Quixote Sancho, expõe no artigo "Lo que debemos a Don Quijote" ${ }^{\text {,55 }}$, publicado em 1961, um balanço da posição contemporânea do Quixote frente às grandes obras clássicas desde Homero até Tolstoi, a fim de responder à pergunta chave do ensaio: o quê devemos a dom Quixote. Para Salinas deve-se o gênero (o significado) de romance moderno. Em seu trabalho o autor apreende do Quixote o conflito entre o indivíduo e a sociedade; realismo simbólico e realismo transcendente.

\footnotetext{
${ }^{53}$ ROSALES. Luis. Cervantes y la Libertad. Volume I. Madrid, Ed. Cultura Hispanica, 2 ed. p.542

${ }^{54}$ Ibidem, 2008, p.251

${ }^{55}$ SALINAS.Pedro. "Lo que debemos a Don Quijote" em Ensayos de literatura hispánica, Madrid,Taurus, 1962
} 
De forma eloqüente o autor afirma que a representação máxima dos valores humanos contidos na obra cervantina se configura nas personagens protagonistas. Em dado momento chega a expressar o valor dual de dom Quixote, afirmando que se trata de "un personaje dual, es la compenetración, es la convivencia Don Quijote y Sancho; es el caminar juntos, de estas dos formas de naturaleza." ${ }^{56}$ Para tanto, Pedro Salinas classifica amo/escudeiro como figuras somatórias, complementares, perspectivas estas distantes da interpretação crítica tradicional. Salinas se refere primeiro aos aspectos positivos identificados em Sancho Pança, ou seja, afirma a existência de virtudes morais na personagem, para em seguida afirmar a evolução destes mesmos aspectos no caráter do escudeiro. Como o próprio autor apresenta

Es prodigioso seguir en el Quijote la historia de Sancho y ver lo que es cuando sale de su pueblo, en sus primeras conversaciones con Don Quijote y lo que es al pie del lecho de Don Quijote; es otro hombre. $^{57}$

A fim de concluir, Salinas termina, pelo viés psicológico, elevando o caráter bondoso, perseverante, mas principalmente paciente de dom Quixote, porque soube converter os vitupérios em etapas a serem conquistadas rumo ao triunfo final. É fato que em trabalhos próximos ao Guía del Lector del QUJOTE a força da opinião deixada pela crítica tradicional que subjetivamente segue paralela aos fortuitos conceitos de escritores como Madariaga, Salinas entre outros. Nesse sentido, a estudiosa Dotras Bravo compartilha da afirmação quando observa: "Es sorprendente cómo, rechazando de plano al crítica tradicional que juzga a los personajes y encumbra subjetivamente a Don Quijote, incurre en ese mismo defecto"..$^{58}$

\footnotetext{
${ }^{56}$ Idem, 1962

${ }^{57}$ SALINAS.Pedro. "Lo que debemos a Don Quijote" em Ensayos de literatura hispánica, Madrid,Taurus, 1962.

${ }^{58}$ Ibidem, 2008, p.249
} 
DÁMASO ALONSO - 1962

Dámaso Alonso (1898-1990), nascido em Madri, dedicou grande parte de sua vida à poesia e à filologia. Pela editora Campo Abierto, em segunda edição, de 1968, publicou Del Siglo de Oro a este siglo de siglas, onde reuniu trabalhos de enfoques diferentes, alguns de investigação documental, panorama do idioma, teoria da literatura e de interpretação de personagens. Em se tratando dos artigos sobre personagens, caberá nesta abordagem o intitulado "Sancho - Quijote, Sancho - Sancho".

Dámaso Alonso, como apresenta Martín Morán, continua no rastro de Madariaga de modo a demonstrar grande conhecimento da psicologia, o autor se pauta nos processos de desenganos pelos quais passam as personagens (abordagem tênue na proposta de Madariaga) ao longo da narrativa, confirmando e explicando as mudanças ocorridas por meio da influência na relação entre os protagonistas. Martín Morán comenta "a quien de verdad sigue es Madariaga: propone en efecto, un paulatino acercamiento de Sancho a las características de su amo, y luego un progresivo alejamiento a raíz de los múltiples desengaños sufridos." ${ }^{59}$ Na visão de Dámaso Alonso importa sobretudo adentrar-se no caráter psicológico de Sancho, a fim de entender as mudanças ocorridas na personagem ao longo da narrativa. A psicologia de Sancho, segundo o autor, se pauta por um grande processo de engano e desengano, tratando-se, portanto, de um realismo psicológico, isto é, retrato interior da personagem.

Segundo Dámaso Alonso, o (auto) engano consiste no envolvimento do escudeiro na loucura do amo, enquanto que o desengano é a percepção/entendimento do mundo fantástico. Refere-se a isso como um processo pelo qual passa Sancho Pança ao conviver com o amo, sendo o ponto culminante do desengano do escudeiro, por se tratar

\footnotetext{
${ }^{59}$ MARTÍN MORÁN.José Manuel. "Don Quijote está sanchificado; el des-sanchificador que lo requijotice...” 1992 p.5(Nota de rodapé 20)
} 
de um aprendizado adquirido ao longo da narrativa, o episódio de Los Batanes, onde o escudeiro adentra na loucura do cavaleiro para enganá-lo. Dessa maneira, se trata, da retomada do escudeiro de sua realidade vital: “- Ea, señor, que el cielo, conmovido de mis lágrimas y plegarias, ha ordenado que no se pueda mover Rocinante; y si vos queréis porfiar, y espolear, y dalle, será enojar a la Fortuna, y dar coces, como dicen, contra el aguijón". ${ }^{60}$ Para o autor importa sobretudo se aprofundar no caráter psicológico de Sancho, a fim de entender as mudanças ocorridas na personagem ao longo da narrativa.

A psicologia de Sancho, segundo o autor, se pauta por um grande processo de engano e desengano, tratando-se, portanto, de um realismo psicológico, isto é, retrato interior da personagem. Segundo Dámaso Alonso, o (auto) engano consiste no envolvimento do escudeiro na loucura do amo, enquanto que o desengano é a percepção/entendimento do mundo fantástico. Refere-se a isso como um processo pelo qual passa Sancho Pança ao conviver com o cavaleiro, sendo o ponto culminante do desengano do escudeiro, por se tratar de um aprendizado adquirido ao longo da narrativa, o episódio de Los Batanes, onde o escudeiro utiliza a loucura do cavaleiro para enganá-lo. Dessa maneira, se trata, da retomada do escudeiro de sua realidade vital: “- Ea, señor, que el cielo, conmovido de mis lágrimas y plegarias, ha ordenado que no se pueda mover Rocinante; y si vos queréis porfiar, y espolear, y dalle, será enojar a la Fortuna, y dar coces, como dicen, contra el aguijón". 61

Interessante vislumbrar nos trabalhos de Madariaga, Rivero, Salinas e Dámaso a atenção concedida à figura do amo. Os autores fazem questão de ressaltar a importância do papel de Sancho no par e no conjunto da obra. A respeito do assunto, chama a

\footnotetext{
${ }^{60}$ D.Q. I. p. 248

${ }^{61}$ D.Q. I. p. 248
} 
atenção Dotras Bravo ${ }^{62}$ ao comentar que nos textos supra mencionados os autores entendem que amo/escudeiro juntos se refinam. Desse modo a crítica cervantina parece conduzir os trabalhos críticos ao longo do século passado, ou seja, ressalta Martín Morán a partir "de las contribuciones de princípios de siglo, gran parte de los estudiosos han seguido la pauta de los maestros". 63

\section{OUTRO RUMO DE LEITURA}

\section{JuAn Bautista Avalle-ArCE Y E.C. RILEY -1973}

“Don Quijote" é um dos artigos que compõem a Suma Cervantina ${ }^{64}$, trabalho organizado por Avalle-Arce e Riley, no ano de 1973. Constituída por trabalhos de renomados cervantistas, onde cada estudioso dedicou atenção a determinada obra do conjunto de obras de Miguel de Cervantes, se trata, pois, de um trabalho referenciado até hoje. O artigo "Don Quijote", originado pelos organizadores da obra, se centra na construção do Quixote como obra exemplar, como um organismo onde há simetrias, segundo os autores, fruto de técnicas narrativas organicamente pensadas e estruturadas por Miguel de Cervantes. É dado maior destaque para a segunda parte, a qual com primor ultrapassou os modelos compositivos e literários de seu tempo. Em linhas gerais, os autores iniciam o assunto afirmando que o Quixote se apresenta como uma forma de proclama literário, pois se desvencilha de paradigmas outrora estabelecidos. Para demonstrar a superação constitutiva alcançada na personagem dom Quixote, AvalleArce e Riley comparam o par quixotesco com os principais personagens de três grandes

\footnotetext{
${ }^{62}$ DOTRAS BRAVO, Alexia. BRAVO DOTRAS. Alexia. Los trabajos cervantinos de Salvador de Madariaga Historia de una idea doble: sanchificación y quijotización. Alcalá de Henares (Madri), Centro de Estudios Cervantinos, 2008, p.249

${ }^{63}$ MARTÍN MORÁN, José Manuel. Don Quijote esta sanchificado el des-sanchificador que lo requijotice....Bulletin Hispanique. Vol.94, N.1, 1992, p.5 (nota 17)

${ }^{64}$ AVALLE-ARCE, Juan Batista; RILEY, E.C. (editores). "Don Quijote" em Suma Cervantina. Madri, Ed. Castilla, 1973
} 
obras antecessoras à obra de Cervantes. Citam, pois: Amadis (1508); Lazarillo (1554) e Guzmán de Alfarache (1599).

Em meio às analises entorno a estrutura narrativa da obra se identifica a análise da construção das personagens protagonistas e a posição dos autores frente às mudanças ocorridas nos aspectos morais e comportamentais de dom Quixote e Sancho. Para os estudiosos "La organización interna de la historia estriba en la interación de lo necesario y probable en el actuar de Don Quijote y Sancho, derivando en un principio del carácter de cada uno, con el azar de las circunstancias externas." 65

A mudança em dom Quixote se manifesta precisamente no Quixote de 1615, onde a história e os acontecimentos derivam da primeira parte sem incorrer em uma mera prolongação dos fatos narrados. As aventuras se desenvolvem e variam "sin sacrificar lo familiar." ${ }^{66}$. Interessante observar que Avallle-Arce e Riley afirmam que antes mesmo do leitor se aprofundar na leitura da segunda parte do Quixote já nota a alteração ocorrida no estado mental do amo, ou seja, a loucura de dom Quixote não é a mesma dos primeiros capítulos da primeira parte da obra "ya está más cuerdo que antes." ${ }^{67}$ Com efeito, se pode em primeiro lugar explicar as modificações ocorridas no estado mental e no caráter do cavaleiro mais na segunda parte, porque nela encontramse as aventuras mais artificiosas, nas quais os valores da personagem são colocados em xeque a todo momento. Explicam os autores, "existe una lógica correlación entre su estado mental que va cambiando y los episódios externos." ${ }^{\text {68 }}$ Acrescentam, o fato de dom Quixote estar mais próximo da sociedade o que favorece o processo de retomada da realidade.

\footnotetext{
${ }^{65}$ Idem, 1973, p.62

${ }^{66}$ Idem, 1973,p.67

${ }^{67}$ Idem, 1973,p.67

${ }^{68}$ Idem, 1973, p.73
} 
A esta mejoría mental, enteramente verosímil, que inicia el progreso penoso del héroe hacia la desilución y restablecimiento final de cordura, se añade outro hecho, exterior, pero íntimo ingrediente de su destino. Es la publicación y êxito de la primera parte, hecho históricamente indiscutible, que Cervantes incorpora en la segunda. ${ }^{69}$

Desse modo, Avalle-Arce e Riley persistem ao longo do artigo na modificação não brusca, mas gradual e lógica do escudeiro. O processo evolutivo do caráter do protagonista é consequência do estudo detalhado da técnica narrativa para mostrar as intenções criativas e técnicas de Cervantes, pois como é dito no artigo alguns pressupostos críticos literários do começo do século, questionavam o valor narrativo técnico e estrutural de Cervantes. Para finalizar, cabe observar que no estudo Sancho Pança não ocupa, como nos trabalhos anteriores, lugar de destaque, mas também não aparece como figura avessa. Embora Sancho apareça como figura cujos valores são independentes, ainda assim está conectado literariamente com dom Quixote, ou seja, o escudeiro aparece no estudo ao lado do amo.

GONZALO TORRENTE BALLESTER - 1975

El Quijote como Juego difere de alguns dos textos anteriores pela perspectiva analítica sobre o Quixote e as personagens protagonistas, uma vez que Gonzalo Torrente Ballester expressa categoricamente interesse por argumentar com base em fundamentos e métodos da crítica moderna. De modo mais expressivo o texto se pauta por tendências teóricas vigentes em meados do século XX, tais como: as concepções teóricas formalistas, o estruturalismo de Vladimir Propp e as categorias linguísticas de Algirdas J. Greimas que parecem sustentar a estrutura da análise do texto. Com respeito ao modo de leitura de Ballester, o próprio autor explica:

No soy un erudito ni un hombre de ciencia, y si lo primero me resulta indiferente, no dejo de deplorar lo segundo y me apresuro a

\footnotetext{
${ }^{69}$ Idem, 1973,p.68
} 
confesar que de muy buena gana hubiera aprendido en alguna parte los métodos de investigación y exposición de la crítica moderna. ${ }^{70}$

Além disso, chama atenção para autores como Ortega y Gasset; Mark Van Doren; Américo Castro; Joaquín Casalduero; Madariaga; contemporâneos como Martín de Riquer, Moreno Báez; Varela, os quais cada qual a sua maneira entenderam o Quixote e, para isso Torrente Ballester os referencia. Apresentar tais estudiosos nesta explanação foi interessante, pois o autor como bom professor organiza e mostra ao seu leitor ou ouvinte de que modo o cenário analítico foi organizado.

A obra se concentra basicamente no estudo da primeira parte do Quixote, sendo o último capítulo dedicado à segunda parte. Não parece necessariamente significar preferência de Torrente Ballester por uma das partes, mas por tratar de questões específicas selecionadas. As perspectivas críticas com respeito ao Quixote e as personagens protagonistas se estabelecem a partir de um jogo cujas regras são determinadas em favor da realidade inventada. O autor se preocupa ao longo da explanação em mostrar o valor estrito da obra literária onde a realidade existente é própria do universo literário. Para discorrer acerca da realidade encarnada no Quixote, Ballester recorre ao trabalho de Erich Auerbach, Mimesis, o qual se dedica em mostrar como se estabelece, se organiza o real no universo literário. Com efeito, esta posição frente ao texto mais uma vez mostra as influências das tendências críticas literárias de princípio de século no entendimento da relação entre amo/escudeiro. Apresenta Ballester

El narrador del Quijote propone, desde las primeras líneas, la entrada en un juego. Para ello dispone, quizás intuitivamente, del arte

\footnotetext{
${ }^{70}$ TORRENTE BALLESTER.Gonzalo. El Quijote como juego. Madrid. Ed. Labor, 1975, p.7
} 
necesario para dar a sus materiales 'la realidad suficiente' para que sean creídos. ${ }^{71}$

Desse modo, o caráter das personagens é formado ao longo da narrativa por idéias consideradas "como material novelesco en las funciones de caracterización que como tal desempeña ". ${ }^{72}$ Afirma Torrente Ballester que alguns traços do caráter de dom Quixote e Sancho mudam da primeira para a segunda parte. No primeiro Quixote o processo imitativo (mais para dom Quixote) está em evidência, ou seja, pertence à primeira parte, enquanto no segundo momento da história as personagens ganham autonomia. A personalidade de dom Quixote é instável, enquanto que a de Sancho, para o autor é compacta e segura, o que faz com que tais características existam em decorrência da operação artística cervantina e não de atribuições reais da personalidade humana. Embora o autor não compartilhe do amparo teórico utilizado por Salvador de Madariaga (a psicologia), o qual se pautava em critérios (extra) literários, Ballester converge para a idéia de evolução/ transformação das personagens.

Outra questão que se procura ressaltar nas análises é o valor de Sancho na narrativa, a equiparação quanto ao valor artístico do escudeiro que se compara com o valor do amo no texto analisado. Torrente Ballester dialoga com Madariaga mais de uma vez quando ressalta a posição de alguns trabalhos críticos que preterem uma personagem a favor de outra. Dessa forma como afirma o autor "ninguno es más importante que el otro, y el uno supone el otro como se supone la luz y la oscuridad, el si y el no."73

Para terminar, são privilegiadas as mudanças discursivas de Sancho, tal como os refrões que passam de incompletos a coerentes, enquanto que as alterações em dom

\footnotetext{
${ }^{71}$ TORRENTE BALLESTER.Gonzalo. El Quijote como juego. Madrid. Ed. Labor, 1975, p.42

${ }^{72}$ Idem, 1975, p.40

${ }^{73}$ Idem, p.88
} 
Quixote residem no fato de retornar à realidade, o que para Torrente Ballester, é quando o cavaleiro se desquijotiza. O episódio dos duques é decisivo para a lucidez de dom Quixote e para o aprimoramento de Sancho Pança. "No hay ningún momento en que esté por debajo de don Quijote: cuando no le supera, se mantiene en pie de igualdad. Es algo que vale la pena Sancho esta ya a la altura de Don Quijote",74

\section{CARLOS FUENTES -1976}

Cervantes o la crítica de la lectura como o próprio Fuentes descreve a perspectiva escolhida para sua obra, "una crítica de la lectura, una crítica de la cración narrativa contenida dentro de la obra misma: crítica de la creación dentro de la creación.". ${ }^{75}$ Trata-se de um ensaio em que o foco é Cervantes como crítico (e criador) de sua própria obra. Carlos Fuentes organiza sua análise a partir de uma correlação do momento histórico espanhol correspondente aos séculos XV da publicação de $L a$ Celestina e XVI da primeira parte do Quixote, apresentações que servem como cenário para sua explanação. O caráter histórico-literário é de certa forma a marca do viés analítico do escritor mexicano.

Dom Quixote e Sancho são no mesmo grau de importância para Fuentes o meio para a dialética cervantina, representam as consciências literárias do passado e do presente espanhol, ou seja, amo coincide com o modelo do herói épico, enquanto que o escudeiro com o estilo pícaro realista que se preocupa em saber o que comer, onde dormir na circunstância presente. Tal fusão acarretara em um projeto crítico literário diferenciado quanto aos esquemas compositivos de seu tempo. Afirma Fuentes “Cervantes fue capaz de ir más allá de la consagración del puro pasado y de la

\footnotetext{
${ }^{74}$ Idem, 1975, p.201

${ }^{75}$ FUENTES. Carlos. Cervantes o la crítica de la lectura. México, 1976, p.15
} 
consagación del presente a fin de plantearse el problema de fusión del pasado y presente." ${ }^{76}$ Para Carlos Fuentes as figuras protagonistas têm finalidade cômica. Não somente dom Quixote e Sancho, mas também a obra se revestem de temas erasmistas, tais como: a dualidade da verdade, a ilusão das aparências e a loucura, ou seja, Cervantes parece estar influenciado, de algum modo, por tais preceitos ao compor o Quixote. Dessa forma, as personagens se complementam ao longo da trajetória narrativa à medida que uma verdade se apresenta de diferentes formas, assim a aparência de dom Quixote, afirma Fuentes, se diversifica na presença de Sancho e vice-versa. Dito de outro modo, amo e escudeiro transitam de uma realidade a outra, enfim se complementam.

De esta manera, el espíritu cómico se pone al servicio de la visión heterodoxa de la doble verdad, y es evidente que Cervantes opta por este atajo al crear las figuras de Don Quijote y Sancho Panza, pues el primero habla el lenguaje de los universales, y el segundo el de los particulares. ${ }^{77}$

Carlos Fuentes se aproxima da teoria da evolução das personagens à medida que verifica em dom Quixote (principalmente) e em Sancho Pança as mudanças ocorridas ao longo de suas trajetórias,isto é, o amo passa de leitor dos livros de cavalaria a ator das próprias aventuras, ou seja, de enfeitiçado pelo excesso de leitura passa a feiticeiro (vetor) dos acontecimentos ao seu redor. O escudeiro participa, dialoga com o universo elaborado por dom Quixote. Comenta o autor: "Si Sancho es el hombre real, participa, sin embargo, del mundo ilusorio de Don Quijote. Pero si Don Quijote es un hombre ilusorio, no deja, por ello, de participar del mundo de la pura realidad de Sancho., ${ }^{, 78}$ Em suma, Fuentes explica as mudanças por meio da perspectiva crítica de leitura que

\footnotetext{
${ }^{76}$ Idem, 1976,p.31

${ }_{77}^{77}$ FUENTES. Carlos. Cervantes o la crítica de la lectura. México, 1976,p.67

${ }^{78}$ Idem,1976,p.67
} 
Cervantes faz da própria obra. Tudo o que está em volta de dom Quixote se quixotiza para corresponder à realidade inventada, mas ao se deparar com o real imaginado (episódio dos Duques, por exemplo) dom Quixote perde a ilusão, se desvencilha dos interesses épicos, a fim de a realidade exceder a imaginação.

$$
\text { MAURICE MOLHO - } 1976
$$

Maurice Molho escolhe Sancho Pança como objeto principal de sua análise ${ }^{79}$, a perspectiva para analisá-lo, por servir-se de determinados critérios, se diferencia dos trabalhos anteriores. Maurice Molho na obra Cervantes: raíces folklóricas reuniu estudos, dividindo-os em três partes, para melhor organizá-los. Dois momentos são dedicados a temas cervantinos e o outro momento se refere em particular à noção de “popular" ${ }^{80}$. A esse respeito, explica Eduardo Urbina

Molho se ocupa de crear un esquema dialéctico entre los pólos listo-tonto que dá origen en su ejecución al conflicto en la narración entre amo y criado, sin que por ello resulten incongruentes las frecuentes variaciones o cambios en el proceder de Sancho, en sus acciones o actitud. ${ }^{81}$

No capítulo III, "Raíz folklórica de Sancho Panza" a análise se detém nos aspectos constitutivos de Sancho Pança, mas isso não implica a falta de correspondência com dom Quixote, uma vez que o tema em pauta, ou seja, a reversibilidade marca o caráter de ambos os personagens. A diferença entre amo/escudeiro consiste necessariamente em um ser tonto-listo e outro loco-cuerdo, porque o mecanismo

\footnotetext{
${ }^{79}$ Das leituras apreende-se que, mais ou menos, da década de 60 em diante os estudos quixotescos dedicam especial atenção a figura de Sancho Pança, os estudiosos chamam atenção para aspectos salientes, como o cômico, da personagem. Márquez Villanueva afirma que o escudeiro suscitou na crítica uma linha de atenção não antes apreciada pela tradição crítica literária.

${ }^{80}$ Segundo o dicionário Larousse (em português) o significado de popular é: pertencente ao povo, simples, singelo, muito conhecido. Já em espanhol, dicionário Espasatem também o significado de popular como algo relativo ao povo, muito conhecido.

${ }^{81}$ URBINA. Eduardo. El sin par Sancho Panza. Parodia y Creación, Barcelona, Anthropos, 1991 p.10
} 
formador é único. Desse modo, o autor justificara não só a complementaridade, o equilíbrio, e a oposição interna de cada personagem, na convivência; mas também as possíveis variações percebidas no par ao longo do texto. Para Maurice Molho, Cervantes reelabora, reinventa Sancho Pança a partir de aspectos de arquétipos populares conhecidos pelos leitores do século XVII.

A leitura acerca da relação entre amo e escudeiro tem ligação com a proposta de Madariaga a medida que o autor entende amo/escudeiro como personagens complementares, desdobradas em suas principais características formadoras ("tontolisto"/ "loco-cuerdo") que oscilam de acordo com o contexto narrativo. Desse modo, não se tratam de figuras estáticas, mas em formação, e nesse caso Sancho é tão importante e necessário quanto dom Quixote, ou seja, são equivalentes na complexidade de suas elaborações. Cabe depreender do trabalho de Maurice Molho suas palavras acerca da questão

No se nos oculta, por tanto, lo que puede haber de artificial en tratar Sancho disociándolo, aunque fuera momentáneamente, de don Quijote, como sería artificial e improcedente un análisis que escindiera a don Quijote expulsando a Sancho de la doble figura inseparable en que coexisten conjunta y alternativamente. ${ }^{82}$

A fim de elucidar, José Manuel Martín Morán observa no texto de Molho os pressupostos de Madariaga quando depreende do contexto o aspecto bifronte amo/escudeiro. A fim de concluir, o texto apresentado mostra outra tendência crítica acerca das personagens quixotescas, eleva-se com rigoroso cuidado a vertente cômica, burlesca e paródica na construção destas figuras, de modo especial a figura de Sancho

\footnotetext{
${ }^{82}$ MOLHO. Mauricio. "Raíz folklórica de Sancho Panza" em Cervantes: raíces folklóricas. Madrid, Ed. Gredos, 1976, págs.231-232
} 
Pança. Abordagem interpretativa que se distancia até mesmo da visão também cômica de meados do século XX. Sancho Pança personagem elevada por Salvador de Madariaga, em 1926, no entanto não tivera lugar de elevado destaque como ocorre no texto de Molho e como acontecerá em alguns dos trabalhos seguintes.

\section{JAVIER SALAZAR RINCÓN -1994}

O artigo "El personaje de Sancho Panza y los lectores del Siglo XVII", $1994^{83}$, é o último trabalho do presente capítulo. Foi elencado em primeiro lugar, pois se trata de uma publicação, de certa forma, recente onde o autor se mostra categoricamente partidário das propostas de Salvador de Madaraiaga acerca das personagens. Dessa maneira, compartilha da opinião de evolução/transformação das personagens tal como foi organizada. Como Javier Salazar Rincón ratifica, o tema teve grande êxito ao longo do século passado no cenário das abordagens quixotescas “[...] algo así como el abecé del cervantista $[\ldots]^{\prime, 84}$. Em segundo lugar, chama atenção no texto a extensão do eco da sanchificação de dom Quixote e quixotização de Sancho já na eminente chegada do século XXI, ou seja, por mais que o tema pareça esgotado isso não parece verdadeiro.

Em estilo bastante expressivo, a análise se pauta fundamentalmente pela figura de Sancho Pança, nos modos pelos quais o escudeiro foi concebido pelo público do século XVII. Algumas das perspectivas nas quais o escudeiro poderia ter sido concebido são: Sancho parodia dos escudeiros cavaleirescos; Sancho aldeão "labrador" pobre; Sancho cômico e cruel entre outros. Antes de se adentrar propriamente em sua perspectiva de leitura, Salazar Rincón confere ao contraponto existente no caráter de

\footnotetext{
${ }^{83}$ Trata-se da primeira versão do artigo. Já a versão analisada é de 1999, segundo o autor está mais ampliada, para melhor apresentar na conferência dada nas universidades de Estocolmo e Uppsal, Suécia, em período de comemorações da morte de Miguel de Cervantes.

${ }^{84}$ SALAZAR RINCÓN. Javier. "El personaje de Sancho Panza y los lectores del siglo XVII". Asociación Internacional de Hispanistas. [Web], 1999, p.1
} 
amo/escudeiro e à influência mutua entre as personagens o grande acerto de Miguel de Cervantes. Para o hispanista o processo se inicia na primeira parte da obra, já no capítulo VII quando dom Quixote convida Sancho para ser seu escudeiro, embora o autor considere que as transformações ocorram já na primeira parte do Quixote, conforma as reais mudanças de Sancho na segunda parte. Nesse sentido, Salazar Rincón coincide com a opinião de Salvador de Madariaga, o qual afirma existir o processo evolutivo gradual e paralelo em amo/escudeiro: um aprende do outro.

As personagens são passíveis dessas interpretações, porque possuem caráter humano e literários intimamente ligados, improváveis no Quixote de separação. Carroll Johnson $^{85}$ elucida, contribuiu com a idéia ao afirmar que a distinção entre pessoa e personagem é ilusória, por que tanto uma quanto a outra são resultado da imagem, da construção mental acerca delas. Nesse sentido, parece de pouca credibilidade para esta linha de estudiosos não argumentar acercar de dom Quixote e Sancho sem tratar da relação e aprendizado de ambos, sem confiar o texto também às realidades humanas. Javier Salazar Rincón vê reforçado na presença de Sancho Pança os aspectos humanos e literários que fazem iluminar a trajetória narrativa dos protagonistas, isto é, o jogo de contrastes e influências entre amo/escudeiro. Desse modo, o autor demonstra que o valor do Quixote está em grande parte na relação entre ambos. Nas palavras de Javier Salazar

don Quijote y Sancho Panza han venido a simbolizar las dos facetas primordiales de todo espíritu humano, que al mismo tiempo se oponen y complementan: el ideal y la realidad, el espíritu y la matéria, lo soñado y lo tangible [...] el hecho de que el Quijote haya ofrecido y

\footnotetext{
${ }^{85}$ JOHNSON.Carroll B. "La construcción del personaje en Cervantes", em Cervantes:Bulletin of the Cervantes Society of America, 8 special issue, $n^{\circ} 15$, vol.1 1995,p.11 ( pgs-1-25)
} 
ofrezca todavia hoy, una lección valida para los lectores de cualquier pais y época. ${ }^{86}$

Em resumo, Sancho aprende a conviver com as fantasias do amo a ponto de apreendê-las como realidades próprias, em contrapartida dom Quixote, ao lado de Sancho, deixa o plano da fantasia e retorna ao plano real. Interessante notar que Salazar Rincón apresenta a evolução das personagens no seguinte sentido: dom Quixote descende e Sancho ascende ao universo idealizado.

\section{CONSIDERAÇÃO PARCIAL DO CAPÍTULO}

Os trabalhos destacados neste primeiro momento refletem um período histórico literário pelo qual passou o Quixote no ocidente, claro que em cada nação a obra repercutiu de maneira particular de acordo com as circunstâncias políticas, intelectuais e econômicas em vigor, como foi apresentado no primeiro capítulo. Concepções filosóficas, teóricas literárias e a própria crítica literária de principio do século favoreceram amplo leque de recursos para conceber a relação dos protagonistas cervantinos. Anthony Close na obra La concepción romántica del QUIJOTE chama atenção para uma questão atualmente bastante conhecida que se trata do importante valor de El pensamiento de Cervantes, de Américo Castro, pouco anterior a publicação da Guía del Lector del QUIJOTE, o qual contribui definitivamente de um lado para o Quixote como romance moderno e, por outro lado elevou Cervantes ao nível de escritor intelectual conhecedor de retórica, poética, e das particulares preceptivas literárias de sua época, fomentando o valor da obra como fruto de um processo de criação e não exatamente só de inspiração, em resumo adentrou na complexidade do Quixote e de seu autor. Dessa maneira, Américo Castro deixa velada a concepção, arraigada no século

\footnotetext{
${ }^{86}$ SALAZAR RINCÓN. Javier. "El personaje de Sancho Panza y los lectores del siglo XVII”. Asociación Internacional de Hispanistas. [Web], 1999, p. 1
} 
XIX, de que Miguel de Cervantes foi um autor só intuitivamente genial. Cabe esta observação, pois o dilema entre Cervantes crítico e criador se reflete frequientemente nos trabalhos das primeiras décadas do século passado.

A leitura das personagens quixotescas foram tomando diferentes rumos, rumos não só que tendem ao controle e rigor de leitura do texto literário, enquadrando-se ao máximo às leis e estruturas da criação da obra, mas também aproximações que se destacam por sua liberação e espontaneidade interpretativa deslocando o texto para o contexto contemporâneo como forma de explicar a realidade vivida. Enfim, os modos de abordagem que se apresentaram aqui e que serão destacados fazem parte do cenário crítico motivado ao longo do século XX. 


\section{CAPÍTUlO III - Outros enfoques. Propostas divergentes acerca do processo evolutivo $e$ influência mutua das personagens dom Quixote e Sancho Pança}

"No hay quijotización de Sancho ni sanchificación de Don Quijote: tal posibilidad me parece ajena al diseño cervantino.” MARTINEZ-BONATI, 1978, p.319

\section{OPINIÃO PRECEDENTE}

Pretendeu-se até o momento organizar um panorama que mostrasse alguns dos traços interpretativos presentes na crítica cervantina do princípio do século XX e suas orientações de caráter filosófico, que influenciaram direta ou indiretamente os pontos de vistas críticos acerca dos protagonistas quixotescos. Em contrapartida, se almejou também apresentar alguns dos trabalhos críticos, mais especificamente depois dos anos 30, nos quais a proposta de Salvador de Madariaga aparece em artigos de renomados autores, apresentando notável freqüência e concordância com a opinião do escritor. No presente capítulo, seguindo certo critério cronológico, prossegue-se com a proposta de indicar outra maneira da crítica cervantina conceber as contribuições do começo do século.

Tendo em vista este caminho percorrido, o presente capítulo se organizou a partir de dois perfis de leitura que estão intimamente relacionados: o primeiro incide sobre um trabalho cuja perspectiva é explicitamente divergente no que tange à evolução e simbiose das personagens protagonistas, levando em conta a instabilidade hierárquica entre amo/escudeiro da primeira para a segunda parte do Quixote; o segundo perfil refere-se a trabalhos das últimas décadas do século $\mathrm{XX}$ onde repousa ainda que indiretamente as principais coordenadas a respeito de amo/escudeiro. Chama atenção 
nestas perspectivas críticas as atuais tendências teóricas literárias para fundamentar/explicar o ethos das personagens. Em suma, buscar-se-á mostrar como tais idéias se manifestaram a fim de apreender outra maneira interpretativa entorno à relação amo/escudeiro.

\section{III.1 - PERSPECTIVA DIVERGENTE}

LEIF SLETSJÖE - 1961

A obra de Leif Sletsjöe Sancho Panza hombre de bien é posterior à obra de Salvador de Madariaga (aproximadamente trinta e cinco anos) no entanto o salto dado entre um trabalho e outro não compromete o diálogo com a proposta madariaguesca. Ao contrário, de modo particular o trabalho do autor norueguês realça a importância e a repercussão com respeito ao tema da evolução e simbiose das personagens na segunda metade do século XX. Sancho Panza hombre de bien tem destaque neste trabalho, pois reflete um modo divergente, no sentido de não compartilhar da simbiose das personagens, ou seja, de apreender o suposto aprendizado de amo/escudeiro a partir das mudanças ocorridas nas personagens quixotescas. Explicando melhor, refere-se a uma abordagem que não comparti da idéia de evolução no caráter das personagens apresentada em Guía del Lector del QUIJOTE. Leif faz uma leitura "literal" do Quixote, chamando a atenção para a mudança brusca ${ }^{87}$ nas características de Sancho Pança de 1605 para o escudeiro de 1615 , isto é, para o crítico se trata da mesma figura, entretanto com organização diferente.

O autor privilegia as duas partes do Quixote e, a partir de fragmentos do livro I e do livro II, compara alguns traços de mudança no caráter, enfatizando o aspecto

\footnotetext{
${ }^{87} \mathrm{O}$ adjetivo brusco funciona como oposto do adjetivo lento empregado por Madariaga para ilustrar o processo evolutivo.
} 
discursivo das personagens e provável ou não evolução de amo/escudeiro. A respeito do que foi dito, Eduardo Urbina na parte introdutória de sua obra El sin par Sancho Panza: Parodia y Creación faz um comentário sobre o estudo de Sletsjöe para afirmar que o autor, por um lado, concorda com Madariaga ao considerar as mudanças e incongruências nas características de Sancho, contudo, por outro lado, vai de encontro com o processo de quixotização quando conclui afirmando que:

existe una ruptura brusca entre el Sancho de la Primera Parte y el de la Segunda, negando así el proceso de ‘quijotización' trazado por Madariaga y que ha venido siendo norma crítica bien arraigada. (URBINA, 1991, p.8)

A obra de Leif S.é composta por 106 páginas, sem contar às páginas que correspondem as notas de rodapé, dados do autor e índice geral. Ao longo da exposição, chama a atenção o trato conferido à analise onde predomina a abordagem objetiva, de rigor científico e estruturado. No tocante a isso, José Manuel Martín Morán (1992, p.6) comenta a tendência de Leif pelo caráter analítico literário das teorias estruturalistas que, neste período estavam em voga. A partir das principais idéias relativas ao perspectivismo lingüístico e possibilidades lógicas do texto narrativo, Leif explica as oscilações no caráter do escudeiro, que parecem transparecer os modos de pensar e de escrever de Cervantes. Cabe notar na explanação o valor dado à figura de dom Quixote, mas por se tratar de uma personagem reconhecida pela crítica cervantina ao longo de séculos, o autor norueguês contempla a necessidade de se estudar cuidadosamente o escudeiro. A esse respeito Leif diz que "los que han se ocupado de los problemas de la novela de Cervantes han considerado como eje y núcleo el caballero mismo, lo que no puede ser de otra manera." (SLESTJÖE, 1961,p.14) 
Trecho a trecho, combinando paralelamente os fragmentos do Quixote de 1605 e de 1615, Leif Sletsjöe trata de algumas das características predominantes no caráter de Sancho Pança. O primeiro aspecto revelado é o estilo simples, natural, ingênuo e medroso da personagem que nas duas partes parece (seu estilo) se manter, entretanto em algumas circunstâncias, o escudeiro se revela valente e descrente em relação ao universo criado por dom Quixote. A respeito da ambição por bens materiais, aspecto este bastante difundido nos estudos críticos, o autor explica que se trata de um traço da constituição da personagem, o qual reflete o momento social vivido pela Espanha daquele período, quando não havia muitas oportunidades de um cidadão ascender socialmente. Para o autor, Sancho não é simples, egoísta, ambicioso, e sim retrato de um homem com medo de ser eternamente pobre, por isso compartilha do propósito do cavaleiro.

A exposição avança no sentido de evidenciar a divisão de Sancho entre a lucidez e a loucura do amo que ora é rechaçada, ora é aceita. As mudanças comportamentais presenciadas ao longo da narrativa existem em decorrência, afirma o autor, da própria constituição da personagem, ou seja, como Cervantes a "pintou", com certas incoerências.

Leif Sletsjöe particulariza o caráter ambivalente de Sancho Pança, como aponta Salvador de Madariaga. A ambivalência para ambos autores consiste no ato de acreditar ("locura") e no de desacreditar ("agudeza") de Sancho em relação ao amo, sendo o escudeiro lúcido quando se trata das fantasias que envolvem dom Quixote e, sendo ingênuo quando está em jogo ser governador da ilha Barataria. Tanto Leif quanto Madariaga autenticam a complexidade em conferir exatas explicações para as oscilações de Sancho, entretanto suas teses se diferenciam, ratificando o que já foi apresentado por 
Madariaga ao afirmar que o escudeiro da segunda parte se sobrepõe ao escudeiro da primeira parte e isso implica evolução. Diferente de Leif, que não verifica evolução nos aspectos de construção do escudeiro de 1605 e o de 1615 , mas verifica uma ruptura no modelo compositivo. "Resumiendo se puede decir que en la novela de 1615 hallamos otro clima.” (SLETSJÖE, 1961, p.69)

Ainda, no texto de Sletsjöe na subdivisão intitulada "Sancho en la crítica" o autor aponta as opiniões de Dámaso Alonso e Salvador de Madariaga com respeito à evolução (quixotização) do escudeiro, a fim de refutar a opinião dos autores com respeito a humanização das personagens. Nesse sentido, não é possível, segundo Leif, somente se ater à essência de Sancho por meio de um processo continuo de onde se espera passar de um estado a outro. A esse respeito explica o autor:

El problema del cambio tan decidido de Sancho, si podemos decir "problema", se resuelve si consideramos su descripción, las pinceladas que añade Cervantes acá y allá en varias ocasiones, no como un ensayo psicológico, sino como la consecuencia de preocupaciones, de variada índole, del próprio autor y por tanto independientes del escudero mismo. (SLETSJÖE, 1961, pgs. 100-101)

FELIX MARTINEZ-BONATI - 1978

O artigo "El Quijote: juego y significación”, publicado na revista Dispositio, no ano de 1978, confirma mais uma vez outro rumo acerca do modo de perceber as mudanças nas figuras protagonistas do Quixote. Martinez-Bonati primeiramente chama atenção para a influência da estética romântica alemã nos estudos críticos, por conseguinte, a influência deste modelo de pensamento ao longo do século XIX, princípios do XX acerca das constituições e variações de amo/escudeiro. O estudioso chama atenção para a importância das orientações desse período na literatura, pois elas 
incitam a algumas possibilidades de interpretação da obra literária, tais como: as convivências e misturas de gêneros, as dicotomias trágico e cômico, o ideal e o real, além disso, observa a repercussão nos estudos de orientação simbólica, a partir de Goethe e de Hegel. Segundo Martinez-Bonati tudo isso contribuiu para o entendimento do Quixote como gênero moderno. Embora tenha observado o lado positivo desse modelo literário, o autor verifica a necessidade de novas reflexões críticas sobre o Quixote e elege para este estudo verificar alguns traços da estrutura compositiva da obra cervantina que possui seu próprio modelo e organização. Além disso, Bonati ratifica o papel do leitor da obra literária como porta-voz do sentido do texto.

Para melhor refletir o pensamento de Martinez-Bonati com respeito ao modo de analisar a obra é importante esclarecer que ele não deseja nem vê-la com olhos de um texto histórico, nem com idéias já pré-concebidas com respeito ao primeiro romance moderno. Ou seja, Martinez-Bonati, em tese, quer abordar o Quixote como gênero próprio e intransferível. O modo eleito para avaliar o texto é, na maior parte das vezes, o científico $^{88}$, como comenta o autor:

El Quijote, pese a haber creado una estructura genérica, en principio abstraíble, no ha dado lugar a un género histórico (ni menos a la novela moderna). Otra cosa es que haya sido imitado en este o en aquel aspecto, y que de múltiples maneras haya influído en el desarrollo de las formas novelísticas. (MARTINEZ-BONATI. 1978 p.317)

No tocante às personagens, a linha de pensamento de Martinez-Bonati segue de certa forma a proposta de Leif Sletsjöe, ou seja, Bonati nega a evolução no caráter de dom Quixote e Sancho Pança. Para tanto, diz que as transformações apresentadas no ethos das personagens derivam da estratégia artística de seu autor, mais do que isso, se

\footnotetext{
${ }^{88} \mathrm{O}$ autor procura não abordar o texto de forma alegórica ou interpretativa simplesmente.
} 
trata de um jogo de justaposições de modelos, com concordâncias e discordâncias de outros estilos que podem ser da mesma figura ou emprestadas de personagens de acordo com a situação/circunstâncias. Uma das riquezas da obra reside, segundo o autor, na convivência das identidades das personagens, identidades imutáveis, as quais oscilam de acordo com a necessidade do autor e a recepção leitora.

Os movimentos que ocorrem em amo/escudeiro refletem ao longo da narrativa a diversidade e heterogeneidade das figuras. "Sus entrecruces subrayan irónicamente su heterogeneidad" (MARTINEZ-BONATI, p.319) Interessante no texto é observar as mudanças nas personagens desde uma perspectiva circunstancial, não interna, mas que se move na verdade dentro do leitor, de acordo com seu conhecimento e percepção diante dos aspectos que se mostram. Bonati se refere a um jogo narrativo que envolve a construção das personagens, muito bem elaborado por Cervantes.

O artigo, de caráter narratológico, versa principalmente sobre o tema da construção dicotômica - razão e loucura - de dom Quixote como forma particular de favorecer o humor contido na obra. Martinez-Bonati verifica que existe no texto cervantino um sentido de realidade compartilhada com os leitores da época e a partir deste consenso se consolida todo o universo fictício do Quixote.

\section{2 - OUTROS ENFOQUES}

En su ya clásico "Don Quixote as a Funny Book", Peter Russell hizo hincapié en la necesidad de estudiar a Sancho bajo dicha perspectiva (URBINA,Eduardo.1991, p.9)

Para melhor esclarecer, os artigos e obras que se seguem se destacam por se basearem em critérios analíticos diferentes dos utilizados por Leif Sltesjöe e MartinezBonati, os quais se orientaram especialmente pela análise de caráter organizacional do 
texto, pela estrutura narrativa em prol do entendimento acerca da não evolução das personagens. Os trabalhos seguintes, não que se preocupem com o nível estrutural compositivo organizado por Cervantes e sim tem o interesse de por em evidencia um traço a mais nos estudos literários da segunda metade do século XX. Período em que por um lado, os especialistas deixaram de se basear em questões biográficas com relação ao autor da obra literária, a fim de se chegar ao sentido do texto e, por outro lado, em suas análises não se prendem estritamente ao texto, à sua textualidade, materialidade como único meio para o sentido, como faz Leif. Os trabalhos, da primeira metade do século XX, parecem refletir um fator agregador que é o modo pelo qual se lê o texto literário, o universo no qual foi concebido, as tendências literárias em voga no período, a conjuntura social, tudo isso é levado em consideração, sem se basear exatamente no fazer literário e na materialidade textual. Além disso, verifica-se a necessidade de se estudar a obra literária segundo sua conjuntura histórico-social. Os estudos não se concentram somente na linguagem, ou seja, o texto sozinho não diz tudo, mas, o leitor, unido a essas premissas, pode sim chegar a uma possível síntese do entendimento da obra literária.

Nesse sentido, observar-se-á nas leituras um leque de possibilidades técnicas interpretativas a respeito das personagens literárias, o modo como foi composto, as nuances ao longo dos séculos, as possíveis leituras que o favorece neste período, mas que não são tão pertinentes em outros momentos, enfim tudo se revela na diversidade dos estudos críticos. Assim, os textos de certo modo refletem o conhecimento e a experiência de seus autores a respeito das tendências teóricas literárias em voga no período em que seus trabalhos foram produzidos com a finalidade de explicar as transformações dos protagonistas quixotescos. 
Em âmbito geral, Anthony Close, em "La crítica del Quijote desde 1925", ao discorrer acerca do modo como o Quixote foi sendo recebido pela crítica do século XX, em especial depois de El pensamiento de Cervantes, de Américo Castro, Close diz que a crítica cervantina se comportara de forma a poder ser dividida. Desse modo, o que diferenciava um modelo de perspectiva do outro era o objetivo com respeito ao texto, ou seja, se o estudioso tendia a perceber o texto segundo à época presente ou conformá-lo segundo seu contexto histórico. Para Close tais manifestações são conseqüiência de "el deseo de superar tópicos cómodos y falaces, someter a un examen más crítico y riguroso la evidencia disponible, ampliar el campo de evidencia o renovar los métodos de análisis, para llegar así a una intelección más exata del pasado”. (CLOSE, 1995, p.318) As propostas seguintes parecem estar imbuídas do desejo de reconhecer aspectos pertinentes ao período de criação e publicação do texto cervantino.

Com efeito, grande parte dos autores, que serão apresentados a seguir pauta seus estudos pelo caráter cômico/burlesco, retomando estes aspectos eminentes no Quixote, os quais por um período foram atenuados pela crítica cervantina. Anthony Close (2005, p.260) explica que nos últimos vinte e cinco anos houve um grande desabrochar de leituras provenientes das teorias de Mikhail Bakhitin e destaca-se a obra publicada em 1965, La cultura popular en la Edad Media y el Renacimiento, onde, entre tão pontuados assuntos se encontra o tema do burlesco, do carnaval em obras literárias. Além do cuidado especial com a figura de Sancho Pança, tal modelo de leitura revela um novo formato no modo de conceber as mudanças e as relações entre amo/escudeiro.

\section{PETER RUSSELL - 1978}

Pode-se comentar, a partir de seus trabalhos, que o crítico britânico fora um verdadeiro revolucionário no âmbito dos estudos cervantinos, já que postulava a idéia 
de uma leitura mais precisa com respeito ao contexto histórico quando o Quixote foi elaborado. O autor levou em consideração não mais as atitudes simbólicas ou alegóricas frente ao texto, as quais, por longo tempo, foram concebidas pela crítica de começo de século XX, mas chamou atenção para uma das características principais do Quixote, isto é, o riso, e daí a análise do modo como o caráter cômico da obra vai se consolidando.

Russell, segundo Anthony Close, está preocupado em seguir, em seu trabalho, a dinâmica da leitura contextualizada do Quixote. Como expressa Close: "Russell persigue el mismo fin: forzar al cervantismo a ser consecuente con sus propias pretensiones de recuperar fielmente el contexto histórico-cultural del Quijote." (CLOSE, Anthony. 1995, p.318).

Em seu artigo "Don Quijote y la risa a carcajadas", 1978, Russell diverge radicalmente da evolução e simbiose de amo/escudeiro. Chama atenção para o cômico, para o riso e a gargalhadas na obra de Cervantes, pois o tema, para o autor, nas primeiras décadas do século XX, segundo a perspectiva cômico/burlesca, foi pouco recorrente. Nesse momento, os estudiosos estavam imbuídos de conceitos do psicologismo biografista, como o faz Madariaga e Dámaso Alonso. Para o autor britânico, os críticos do século XX haviam se distanciado da intenção fundamental de Cervantes em relação ao Quixote: fazer rir para aprender. Diz o autor: "Sucede que, a fin de cuentas, el Quijote fue concebido por Cervantes como un libro que haría reír sus lectores, y la crítica literaria, por razones que luego mencionaré, habla de muy mala gana de la risa." (RUSSELL,1978,p.410). De modo geral, cabe mencionar que, em tese, o estudo de Russell, não se pauta por uma análise somente de impressões, pois se preocupa em mostrar, desde a publicação da primeira parte da obra, na Inglaterra e na França, como o Quixote foi concebido pelos leitores daquele período, estendendo, 
aproximadamente, esse modo de leitura, segundo ele, aos dois séculos subseqüentes. Trata-se, pois, do modo divertido de ler o Quixote afirma Russell: “[...] en la Europa renacentista los españoles tenían una fama especial como chistosos, particularmente sobresalientes en el comportamiento y los dichos divertidos o ingeniosos." (RUSSELL, 1978, p.426)

Para o autor, tal perspectiva de leitura se rompe no século XIX, quando o leitor passa a se identificar com o cavaleiro. Uma das correspondências possíveis do leitor com o protagonista é dada por Lukács que interpreta tal correspondência como a peregrinação do indivíduo problemático rumo a si mesmo, ou seja, rumo ao autoconhecimento, o que, para o autor compõe a tipologia do romance moderno.

Desse modo, o texto trata de dom Quixote e Sancho Pança, no entanto sua análise concentra maior atenção na figura do cavaleiro. Russell vai de encontro com a idéia de sanchificação e quixotização, pois, para o autor as mudanças ocorridas em dom Quixote e Sancho Pança são circunstanciais dado que voltam aos estados de origem no fim do romance. São recursos de estilo utilizados por Cervantes que favorecem o cômico identificado na relação amo/escudeiro.

\section{EDWIN WILLIAMSONS - 1984}

El Quijote y los libros de caballerías de Edwin Williamsons também traz novas perspectivas para as mudanças de amo/escudeiro, já que trata da evolução e simbiose organizadas por Salvador de Madariaga de modo a interpretá-las a partir de um novo enfoque. Ao longo da leitura da obra de Williamsons quando diz respeito às mudanças no discurso dos protagonistas, inversão de papéis e o aprendizado de Sancho Pança o autor encontra outra explicação, de vertente mais técnica, e portanto menos subjetiva, 
para os fenômenos apresentados nos protagonistas. Entretanto, parece em alguns momentos elevar à superfície do texto pensamentos muito parecidos com os organizados pelo escritor corunhês.

Williamsons organizou seu trabalho em cinco capítulos: o primeiro capítulo dedica atenção à origem das novelas de cavalarias ou, como denomina, a origem do romance caballeresco, destacando os procedimentos da arte narrativa de Chrétien de Troyes, quem consolidou de modo estendido e sistemático, os relatos bretões do rei Arthur. Comenta Edwin;

La fusión que realizó Chrétien de las leyendas bretonas del rey Arturo con el sistema de valores de la caballería cortesana y la mentalidad neoplatónica de la Francia del siglo XII produjo, en palabras de W.P. KER, una 'revolución de la que se derivan en mayor o menor grado todas las formas y configuraciones posteriores del romance y la novela'. (WILLIAMSON, Edwin. 1991, p.34)

No segundo capítulo Williamson direciona seu olhar para a evolução do gênero, romance caballeresco na Espanha, do século XIII, quando o enredo das histórias do rei Arthur e os procedimentos narrativos do gênero obtiveram variadas versões, por longo período. As histórias do rei Arthur nos textos de Chrétien se estruturavam a partir de motivos mitológicos e o foco narrativo em boa parte se centrava na figura do herói. Já as histórias (re)elaboradas por Montalvo, na península Ibérica, se revestiam de fundamentos de vertente religiosa cristã e, além de se centrar na figura do herói, priorizava também o entorno onde aconteciam os feitos de Arthur. A fim de ilustrar, o interessante estudo a respeito da obra de Chrétien, afirma Williamson

El romance artúrico empieza a cambiar, pasando de la ordenación simbólica de la experiencia de un individuo a la descripción de un microcosmos histórico en el que se puede 
demostrar cómo las verdades cristinas se realizan en el desarrollo de un destino colectivo a lo largo de un muy extenso período de tiempo. (WILLIAMSON, p.64)

Com base no discorrido nos dois capítulos iniciais, os três capítulos restantes seguirão a pauta a partir do entendimento do leitor acerca do apresentado. Desse modo, quando Williamson trata no capítulo III do romance de cavalaria e da loucura de dom Quixote, estabelece relação com os conhecimentos pré-concebidos acerca da origem e constituição das novelas de cavalarias; o mesmo ocorre no capítulo IV quando trata dos recursos de estilo elencados por Cervantes em dom Quixote e Sancho. Por último, no V capítulo traça uma linha evolutiva a começar pelo romance de cavalaria até o romance moderno, onde as personagens seguem o mesmo caminho ascendente. A fim de acrescentar ao que foi dito, para Edwin, Cervantes conhece tão bem a estrutura desse gênero, pois ao criar o Quixote pensa não só em apontar as extravagâncias e incoerências poéticas (literárias) desse tipo de relato, como também fazer rir por meio de seus protagonistas aos leitores da época. Em tese, a paródia das novelas de cavalarias não era o principal objetivo de Cervantes, no entanto se refere mais a um subterfúgio para renunciar de modo admirável o gênero e com isso experimentar un arte nuevo.

Para tanto, Williamson se apóia ora em alguns conceitos das preceptivas poéticas dos séculos XVI e XVII, ora se identifica com as teorias modernas, a fim de melhor demonstrar os critérios compositivos utilizados pelo o autor do Quixote. Em meio a isso, o autor diz que uma das intenções de Cervantes com sua obra fora a de incitar nos leitores da época riso e a admiratio $^{89}$ que se conforma pelo funcionamento orgânico (pela coerência) dos procedimentos narrativos. Em suma, o Quixote, segundo o

\footnotetext{
${ }^{89}$ Segundo explica o autor, em âmbito geral, admiratio é o ponto intermediário entre o maravilhoso e a verossimilhança.
} 
autor, está no meio termo entre o romance medieval e o romance moderno. Como descreve Williamson a respeito da intenção de Cervantes

La admiratio, lo mismo que la risa, forma parte de su intención en el Quijote, pero si en cuanto efecto deseado es completamente tradicional, la manera de conseguirlo constituye una novedad. (WILLIAMSON, p.134)

No capítulo III "El Romance caballeresco y la locura de don Quijote" o autor inicia as análises e interpretações acerca das personagens protagonistas, ou seja, a partir deste momento Williamson chama atenção, principalmente, para a loucura de dom Quixote. Segundo o estudioso, a instabilidade mental do amo se trata de um mecanismo compositivo literário utilizado por Cervantes, a fim ter "rienda suelta" na sua criação. Desse modo, de um lado favorece o inusitado (admiratio e o riso) na obra, por outro lado, declara as extravagâncias das histórias de cavaleiros. Só mais adiante Williamson abordará acerca das oscilações no comportamento do escudeiro cuja função narrativa está mais para antagonista de dom Quixote isso porque Sancho enfatiza a diferença entre a vida de dom Quixote e a vida dos cavaleiros contada nas novelas de cavaleiros.

Neste âmbito, a idéia de evolução e mudanças nas características das personagens aparece. Diferentemente de Salvador de Madariaga, Williamson não confere à loucura de dom Quixote um significado cuja função seja o caminho de aprendizado e retomada à realidade, pois, como descreve o autor, a obra não conforma a progressão do estado demente ao estado sadio do cavaleiro. Dom Quixote sempre enxerga as coisas como são a não ser que a situação ou o lugar o faça recordar o universo da cavalaria, ou seja, o protagonista oscila entre a visão aparente e a visão real sem se alienar totalmente do universo que o cerca. 
Em se tratando da evolução da personagem, o tema reside no fato de dom Quixote, a cada capítulo, não encontrar no mundo real correspondência com o universo almejado, desvencilhando-se cada vez mais de sua loucura. No decorrer da narrativa a relação ideal-real se torna cada vez mais distante, com efeito, os motores de toda a mudança no cavaleiro são as circunstâncias propriamente dita e Sancho Pança que, com outras personagens, as provocam. Em outras palavras, a evolução da personagem que trata o autor está em conformidade com a evolução do relato, isto é, as personagens evoluem à medida que a narrativa evolui. Diz Edwin, "toda la novela se construye a partir de la división que existe entre la fe inquebrantable de don Quijote en la veracidad de los libros de caballerías y su capacidad para poner esta creencia en práctica." (WILLIAMSON, p.140)

A respeito de Sancho Pança, Williamson parte da afirmativa que o escudeiro em boa parte do tempo exerce a função de personagem antagonista, que por meio do discurso do universo cavalheiresco ironiza a existência de Dulcinea, desencadeando, em seguida, uma série de situações também irônicas. Trata-se de um jogo de perspectivas cuja função por um lado é fomentar a loucura do cavaleiro e, por outro lado, ironicamente (des)estabelecer o mundo imaginado por dom Quixote.

O marco decisivo da mudança na relação entre amo/escudeiro ocorre no capítulo $\mathrm{XX}$, da segunda parte, em conseqüência da situação de medo vivenciada por Sancho Pança e sua linguagem é forçada a mudar para enganar e, por conseguinte, para ter controle sobre o cavaleiro. O escudeiro não se "quixotiza", mas se modela externamente, a fim de contribuir com a manutenção da loucura de dom Quixote. O modo como Sancho age se trata de mais uma técnica narrativa elencada por Cervantes para avivar a história do louco. 
Em resumo, a oposição/aproximação existente entre dom Quixote / Sancho se estabelece por meio da linguagem onde se configura a ironia cervantina que para Edwin sugere interpretações para, em seguida, causar frustração. Com base neste modelo estrutural para as personagens, os papéis de amo/escudeiro se invertem, a fim de provocar alguns conflitos de âmago literário, tais como: os níveis metafórico e literal do discurso; simbolismo e ironia; autoridade e interesse individual. Segundo Williamson as mudanças nos papéis das personagens ocorrem no discurso quando Cervantes demonstra o modelo de dom Quixote em Sancho e vice-versa. Dessa maneira, as oscilações comportamentais e discursivas das personagens nada mais são senão conseqüência da técnica narrativa organizada pelo autor do Quixote, o qual sem sombra de dúvida experimenta e utiliza os recursos possíveis em seu tempo para dar consciência de suas figuras e celebrar o diálogo entre as distintas possibilidades narrativas.

\section{EDUARDO URBINA -1991}

Eduardo Urbina em El sin par Sancho Panza: parodia y creación, da série cervantina da Associação de Cervantistas, (1991), dialoga com o tema da sanchificação e quixotização a partir da perspectiva paródica. Para Urbina as oscilações comportamentais de Sancho Pança e de dom Quixote são mecanismos paródicos que Cervantes utiliza para avivar às personagens (de maneira especial, Sancho Pança): "Esta duplicación paródica no implica, sin embargo, ‘quijotización' por parte de Sancho. Se trata de una transposición de papeles que ocurre como ejemplo de artificio llevado a cabo por Cervantes [...]" (URBINA, p.142) Para acrescentar, Urbina apreende da conversa de Sancho com Tereza Pança (mesmo recorte que faz Madariaga) o exemplo do artifício paródico para justificar a falta de decoro do escudeiro. "Cervantes compensa 
la falta de decoro críticamente y consigue que su juego cómico produzca admiración a pesar de la potencial inverosimilitud.” (URBINA, 1991, p.142)

Isso explica o porquê do escudeiro possuir, na segunda parte da obra, características notáveis, que são reflexos do cruzamento paródico com o amo, diferentemente de Madariaga, que interpreta Sancho Pança como uma personagem (pessoa) que aprendeu, portanto evoluiu. Urbina procura verificar as oscilações das personagens, ao longo da narrativa, segundo uma visão burlesca.

De modo geral, Urbina apresenta Sancho, na primeira parte da obra, como um modelo paródico, já na segunda parte, mais aperfeiçoado, se estabelece de outro modo por se saber famoso, sendo já personagem de livro impresso ${ }^{90}$. O escudeiro de 1605 (mais próximo à paródia do modelo Gandalín) se distancia do escudeiro de 1615, pois evidencia novas características dadas a favor de um processo burlesco, diferente da personagem de 1605 que, para o autor, reflete exclusivamente a paródia dos livros de cavalaria: "En la Segunda Parte Sancho actúa con mayor amplitud e independencia, según conocimientos ganados y alejándose en parte de la parodia que sustenta." (URBINA, 1991,p.139) Para Urbina, o aparente quixotismo consolidado pelo paralelismo entre amo e escudeiro, proposto por Salvador de Madariaga de Sancho emerge do ser companheiro de aventuras e, logo, do ser companheiro de fama, portanto como decorrência do paralelismo paródico entre ambos personagens.

O autor depreende das oscilações discursivas de Sancho, na segunda parte, a inclinação de Cervantes em favorecer o escudeiro, uma vez que permite à personagem

\footnotetext{
90 Para Urbina Cervantes incorpora os comentários críticos, a fim de enriquecer a história de amo/escudeiro e contar com a presença de Sancho Pança mais dilatado e participativo. Isso explica o autor através do processo do encantamento de Dulcinea.
} 
um enriquecimento considerável de aspectos em sua criação. "La paródia del escudero realizada em 1605 no queda totalmente abandonada sino que toma nueva dirección." ${ }^{91}$

\section{José MANUEl MARTín MORÁN -1992}

José Manuel Martín Morán não só publicou “Don Quijote está sanchificado; el des-sanchificador que lo re-quijotice...", 1992, Bulletin Hispanique, a respeito do sedutor tema da sanchificação de Quixote e quixotização de Sancho, como também em outros trabalhos de extensão concentrou sua atenção a distintos temas das obras de Cervantes. Alguns dos textos de Martín Morán são: "O Quixote e a leitura"; "La coherencia textual del Quijote" e El QUIJOTE en ciernes. Los descuidos de Cervantes y las fases de elaboración textual. $\mathrm{O}$ artigo põe em evidência parte da proposta de Madariaga, pois a análise se concentra na evolução do par protagonista, deixando de lado a influência mutua de amo/escudeiro. O trabalho apresenta de um lado a consolidação da idéia e, por outro lado, a recepção na crítica do século XX. Segundo Alexia Dotras Bravo se trata de un estudo que "pone en entredicho la teoria de Madariaga por primera vez" ( DOTRAS BRAVO,2008, p.275)

Nas páginas iniciais do artigo, Martín Morán expressa a opinião de que a proposta de Salvador de Madariaga desencadeou na crítica do século XX o leque de interpretações sobre amo e escudeiro. As análises críticas denotaram atenção em aprofundar desde diferentes focos da suposta evolução das personagens. As idéias de sanchificação e quixotização, segundo o autor, retumbaram ao longo dos anos, porque o texto cervantino proporciona possibilidades interpretativas que variam de acordo com o tempo e cultura.

\footnotetext{
${ }^{91}$ URBINA. Eduardo. "Sancho Panza; parodia y creación en Don Quijote" in El sin par Sancho Panza. 1991, p.139
} 
O professor Morán pauta a análise das personagens pelo viés organizacional do texto, enfatizando as estruturas semânticas onde se inserem dom Quixote e Sancho. A figura do cavaleiro é contemplada ao longo da exposição, referindo no texto, esporadicamente, a figura do escudeiro. Como fazem outros críticos acerca da transformação do caráter de dom Quixote e Sancho da primeira para a segunda parte da obra, para Morán as personagens passaram por um processo de transformação, brusca transformación, que favorece. A aparente concordância com a proposta de Salvador se diverge à medida que no discorrer da explanação, o autor explica que o retorno do cavaleiro ao estado "sadio mental" se relaciona com a lógica compositiva do relato cervantino. Para tanto, o autor explica que as personagens apresentam ao longo da trajetória outras marcas no seu caráter de acordo com as circunstâncias onde são colocadas em evidência, portanto amo/escudeiro não possuem vida própria, não evoluem por consequência do aprendido. Ou seja, são figuras formadoras de um processo narrativo muito bem articulado. Com efeito, paralelo a isso as personagens parecem seguir a ordem evolutiva narrativa, a qual sinalizou aspectos do romance moderno.

Em outras palavras, a suposta evolução gradual no caráter de dom Quixote seria conseqüência, se vistas por este ângulo, das experiências conflitivas com o mundo que o herói é obrigado a defrontar. O estudioso trata necessariamente de analisar ao mesmo tempo as duas premissas (a evolução das personagens e o primeiro romance moderno), a fim de mostrar que não há evolução no caráter de dom Quixote, porém se trata de novos modelos que vão sendo construidos. Afirma Martín Morán

Así pues, descartada la tesis del crecimiento de don Quijote, al menos en lo que a sus manifestaciones verbales se refiere, habrá que reconocer que en lo referente a los hechos don Quijote en la II parte 
parece mostrarse completamente distinto a la I " (MARTÍN MORÁN, 1992 , nota $40^{92}$ )

Os aspectos melancólico e desanimado de dom Quixote, às vezes demonstrados nos capítulos, não implicam no processo evolutivo rumo à melancolia e morte. As duas partes do Quixote retratam momentos da apatia do cavaleiro frente às situações, claro que a segunda parte da obra, devido à superioridade de circunstâncias onde amo/escudeiro estão postos, evidencia com clareza seus estados de ânimo. Em suma, os fatores externos às personagens provocam as transformações que se evidenciam por meio do discurso onde os fatos anteriores são rememorados e desenrolados sobre outro enfoque.

Para finalizar, Martín Morán desacredita na sanchificação e quixotização. Para o autor, se trata de personagens que se aproximam na segunda parte pela vertente loco/cuerdo. Explicando melhor, Sancho apresenta a parte mais inteligente de sua constituição, enquanto dom Quixote não necessita mais se mostrar louco a todo instante, porque se fez conhecido. Soma-se a isso, a perceptível mutação na personalidade de dom Quixote que se explica por meio do processo denominado disimilación, motivado pelos fatores externos e pela criação de Sancho quem se tornou parte complementar na criação do cavaleiro. Para ilustrar a afirmação, Alexia Dotras Bravo comenta

La disimilación (grifo nosso), el proceso por el que se diferencia de lo que era antes, no rompe el equilíbrio de don Quijote, los aspectos esenciales de su ser. Las disimilaciones también responden a un plan narrativo de su autor, el personaje cambia, cambia su actuación para responder a la variedad que deseaba Cervantes en su obra sin truncar la unidad del mismo. (DOTRAS BRAVO, 2008, p.279)

\footnotetext{
${ }^{92} \mathrm{O}$ ensaio utilizado não contém o número de páginas, por isso pareceu-me razoável ao contrário de numerá-las apontar o número da nota de rodapé, uma vez que esta raramente se modifica.
} 
AUGUSTIN REDONDO - 1997

Augustin Redondo em Otra manera de leer el QUIJOTE:historia, tradiciones culturales y literatura organiza os temas analisados acerca do Quixote em um cenário estruturado a partir da perspectiva histórico-social da produção da obra literária, pois para o autor "el condicionamento histórico-social puede ser, algunas veces, mucho más directo y orientar más aún la composición del texto." (REDONDO,A. p.38). Dentro do projeto histórico-social Redondo examina alguns aspectos do homem e da sociedade, das classes sociais, da monarquia influenciadora de costumes e hábitos para a sociedade da época; de lendas folclóricas recorrentes na literatura, da melancolia e da agressividade física como características comportamentais de um período. Tudo com o objetivo de adentrar no universo da obra cervantina onde as relações próprias do mundo real são recriadas magistralmente no âmbito fictício. Com efeito, o principal objetivo de seu trabalho é a tradição popular, ou seja, o leque de produções culturais peculiares nos séculos XVI e XVII, tais como: os ritos festivos e as atividades carnavalescas. As análises de Redondo versam sobre o caráter cômico/burlesco da obra e pode-se classificar o Quixote como obra predominantemente criada para o entretenimento, sendo os recursos da intertextualidade e da estrutura paródica alguns dos mecanismos utilizados por Cervantes, a fim de incitar o riso.

Augustin Redondo tem conhecimento amplo dos trabalhos especializados nos temas da cultura popular, carnaval, mito, entre outros, no entanto, elenca, em especial o trabalho de Mikhail Bakhtin La cultura popular en la Edad Media y en el Renacimiento, publicado em espanhol no ano de 1974, para consolidar as análises das personagens protagonistas do Quixote. Ao se apoiar em tão modernas teorias frente à criação de Cervantes, a proposta acerca da evolução, das mudanças nas características de dom 
Quixote e Sancho se distanciam definitivamente das tendências críticas literárias peculiares no período da publicação da Guía del Lector del QUIJOTE.

A obra de Redondo conta com quatro capítulos. Quanto aos capítulos, cada qual possui significativo número de subdivisões, a fim de melhor particularizar as partes que constituem o tema proposto no estudo. Desse modo, o capítulo I intitulado "Texto y contexto: problemas de intertextualidade" se modela por uma linha de pesquisa especialmente histórico-social desde a publicação de Lazarillo ao Quixote, ou seja, o autor contextualiza para o leitor o momento e a situação histórica quando o Quixote aparece. São levadas em conta as relações sociais (homem e sociedade), econômicas, políticas, religiosas e espaciais desse período, a fim de melhor aproximar o leitor do modo de criação da obra cervantina.

No capítulo II denominado "Personajes cervantinos bajo nueva luz" as análises cuidam de evidenciar a essência de algumas das principais personagens da obra. Melhor explicando, Redondo procura indicar a provável orientação cervantina para construir Sancho Pança, dom Quixote, Aldonza Lorenzo/ Dulcinea, Ginés de Pasamonte /maese Pedro e o cavaleiro del Verde Gabán. No capítulo III o autor propõe outro modo de abordagem de alguns capítulos dos dois Quixote. E, por fim, o capítulo IV intitulado "A modo de conclusión: parodia, lenguaje y verdad en el Quijote el episodio del yelmo de mambrino" o autor chama atenção para o horizonte de perspectivas proporcionadas por Cervantes, que soube dirigir o jogo entre o ser e o parecer. De maneira crível, revelar a realidade de uma época, enfim o autor chama atenção para o leque de representações e reflexões possíveis emergidas do modo como Cervantes organiza o texto.

Com efeito, o destaque da leitura é dado ao capítulo II denominado "Personajes cervantinos bajo nueva luz", porque consta da opinião do autor a respeito das 
oscilações, mudanças das personagens. As análises, em linhas gerais, se configuram a partir do modelo dos ritos carnavalescos (carnaval) frequentes nas últimas décadas do século XVI e principio do século XVII. Paralelo a este modelo popular de festa, o autor também se encarrega de alguns aspectos da tradição folclórico-literária do período para delinear alguns traços característicos na formação das personagens.

A respeito de dom Quixote e Sancho Pança Augustin Redondo se interessa pela raiz carnavalesca das personagens. Para o autor a constituição de amo/escudeiro está no modelo opositivo carnaval-quaresma que

corresponde al contraste entre gordos y flacos, personaficado bajo la forma del combate simbólico entre don Carnaval y doña cuaresma, en que el primero, medroso y cobarde, harto de comida y vino, forzosamente había de resultar vencido. No es de extrañar que el Carnaval aparezca bajo la forma de un personaje rechoncho, de abultada barriga, rodeado de manjares carnosos, sustanciosos, a horcajadas a veces sobre una cuba de vino, mientras la Cuaresma tiene un aspecto de una vieja larga y demarcada que enristra un largo remo en lugar de Lanza y va acompañada de pescados y alimentos poco nutritivos [...] (REDONDO, Augustin. 1997, pgs.193-194)

A partir desse fio condutor, do universo carnavalesco e cômico do Quixote, se esclarecem as oscilações comportamentais das personagens. Redondo afirma que no sistema carnavalesco a ordem do tempo e dos atos humanos são a todo instante subvertidos, desse modo as personagens que, segundo o autor, partem do mesmo principio criador (de tradição carnavalesca) são opostas e complementares, à medida que emprestam amo/escudeiro traços de suas respectivas naturezas. Em suma, Sancho e dom Quixote por se tratar de figuras carnavalescas possuem caráter reversível. Diz Redondo "el juego de reversibilidade de los personajes, según el enfoque adoptado, y 
los cruces que existen entre ellos cada vez que hay inserción de los rasgos de un tipo de representación en el otro.” (REDONDO, Augustin. 1997, p.196)

Acerca de dom Quixote o autor esclarece alguns aspectos de sua elaboração pelo viés da tradição folclórico-popular, do contraste entre gordos e fracos e retoma a idéia de figuras opostas e complementares. Augustin Redondo nesta subclassificação tem um amplo estudo a respeito da origem do nome da personagem, começando pelos significados de Quijada.

Para concluir, o estudioso ao tratar das personagens protagonistas, em especial na parte dedicada a Sancho Pança, em tese, diverge das leituras críticas estritamente interessadas no escudeiro dotado de concepções da tradição culta ou popular; figura rústica; estereótipo do camponês da tradição oral do Século de Ouro; modelo arquétipo "tonto-listo", entre outros. Para isso, Augustin Redondo fomenta em seu trabalho uma proposta nova de leitura na qual se pretende combinar duas visões de mundo.

\section{CONSIDERAÇÃO FINAL A RESPEITO DO CAPÍTULO}

Depreendendo dos trabalhos apresentados nos capítulos II e III foi possível perceber que, ao longo do século XX, houve mudanças no modo de as relações no par protagonista do Quixote, dando um passo à frente, bem interessante, que emerge de uma preocupação mais textual em relação aos estudos literários, além de se observar grande dedicação dos estudiosos às obras de Cervantes.

Primeiro os estudiosos relacionavam o universo fictício da obra literária com acontecimentos e experiências da vida real e isso se dava mais especialmente nas primeiras décadas do século. A literatura tornou-se, por um momento, o meio de representação e entendimento do ser e seu meio. As figuras de dom Quixote e Sancho 
interpretadas com palavras eloqüentes refletiam às inquietações e as inconstâncias próprias dos seres humanos. Nesse sentido, a conversão do real para o fictício se consolidava por meio das palavras do autor Cervantes, que entendeu o seu meio e soube expressá-lo poeticamente. Por isso, por um período, a melhor maneira de reconhecer o universo cervantino fora reconhecer o autor e seus limites como criador e crítico. Esta atitude frente ao texto guarda resquícios de tendência simbólica romântica.

Em segundo lugar, com o surgimento e apogeu das propostas baseadas em critérios teóricos, os trabalhos críticos passam a adquirir outro sentido para muitos estudiosos, que não aderiram à opinião simbólica ou alegórica de amo/escudeiro. $\mathrm{O}$ estudo pautado pela estrutura do texto, no modelo de criação como protótipo do romance moderno pareceu a estes especialistas o melhor caminho para se adentrar no estreito mecanismo narrativo de Miguel de Cervantes. O Quixote, neste modelo analítico, se enquadra em um sistema cujo mecanismo narrativo fora composto organicamente. Desse modo, as leituras quixotescas procuram se afastar ao máximo de qualquer interpretação impressionista relacionada ao corpus cervantino.

Desta última proposição destacam-se duas vertentes de trabalhos críticos: o primeiro tipo parece seguir certo modo de abordagem na qual se procurava adequar o texto às novas ciências lingüísticas e/ou literárias e o outro tipo de análise procurou resgatar, ou melhor, chamar atenção para a leitura da obra orientada a partir das premissas poéticas que se destacaram quando o Quixote fora concebido. Os textos apresentados, em síntese, se pautam por uma leitura particular de representação pessoal mais ou menos científica, ou seja, parte, cada qual em sua medida, de uma concepção criadora ou de um organismo narrativo literário organizado para explicar as dimensões passíveis de serem identificadas na relação entre as personagens do Quixote. 
A tese da sanchificação de dom Quixote e quixotização de Sancho aparece diluída, haja vista a escolha de uma ou outra das premissas que constituem o processo organizado por Salvador de Madariaga: evolução e simbiose. É importante destacar o eco alcançado pela proposta interpretativa de Madariaga. Alguns trabalhos dedicam atenção à evolução, ora de dom Quixote, ora de Sancho Pança como meio abalizador do romance moderno. Já outros estudos elegem tratar da simbiose, tema este encontrado nas características invertidas ou na reversibilidade de amo/escudeiro. Muito raramente, as propostas tratam de explicar as mudanças das personagens pelos dois lados do processo, ou seja, de dom Quixote se sanchificar e Sancho se quixotizar. Em suma, o primeiro subtítulo do capítulo anterior finaliza o atual capítulo, pois mais uma vez é possível dizer da repercussão positiva da proposta de Madariaga na crítica do Quixote. Com efeito, é pertinente afirmar que até hoje a crítica cervantina encontra nos temas do autor estímulo para admirar sua interpretação refutando ou concordando dela. Talvez, porque se refira a uma questão bastante interessante, global no sentido de possibilitar o cotejo entre vida humana e arte, provável ainda por se referir diretamente às personagens principais em seus aspectos mais fundamentais: o modo de presença e o discurso. Enfim, não importa em que medida os conceitos de Salvador de Madariaga são representados, contudo perceber que quando se refere a aspectos de mudanças nas características das personagens, Salvador de Madariaga parece ainda opinar.

Finalmente para concluir, cabe assinalar as palavras de Anthony Close, em $L a$ concepción romántica del QUIJOTE, quando, em meio a abordagem acerca da influência da Geração de 98 espanhola nos estudos cervantinos, exemplificando em primeiro lugar a percepção crítica de Unamuno frente ao Quixote, o autor eleva o grau de importância do Guía del Lector del QUIJOTE. Neste âmbito Close diz que: 
A partir de esta clase de datos ${ }^{93}$, y siguiendo la pista dejada por Unamuno, Madariaga construyó su retrato psicológico de don Quijote como Hombre de Fe, ceñido al ideal que acaricia a pesar de sus dudas que, si empiezan por ser reprimidas de una forma semiconsciente, acaban por vencer. El libro de Madariaga conllevó una mejora de la calidad de los estudios cervantinos, porque los críticos se vieron obligados a descender del nível de generalización al de los detalles concretos. (CLOSE, 2005, p.190)

\footnotetext{
${ }^{93}$ A classe de dados referida por Anthony Close se resume em questões, tais como: a relação entre a personagem de dom Quixote e Alonso Quijano; como Cervantes a constrói; como se estabelecem a relação de continuidade e de mutua interpretação na personalidade do amo. Estas são algumas das indagações apresentadas pelo autor.
} 


\section{CAPÍTULO IV - Perspectiva de leitura das (im)posturas de dom Quixote e Sancho Pança no capítulo XLI, da segunda parte}

"Según las teorías de la imitación que se desarrollan en el Renacimiento, al calor de la retórica, la grandeza de una obra literária no residia en lo que hoy llamamos originalidad, sino en la belleza, armonía y funcionalidad de la composición, que lo mismo que la miel de la abeja, que procede de muy diversas flores, así se podía y debía acudir a infinitas fuentes para componer un texto: tanto en el plano elocutivo como en el de la invención."

GRIGERA, 1994

\section{COMENTÁRIO PRELIMINAR DO CAPÍTULO}

A proposta para este último capítulo do trabalho se organiza fundamentalmente pela análise de um episódio, da segunda parte do Quixote, que se refere à aventura sob o cavalo de madeira Clavilenho, no momento em que dom Quixote e Sancho Pança se deparam com um cenário fantasioso, no capítulo XLI da segunda parte. O presente capítulo enfoca de modo particular a relação entre dom Quixote e Sancho Pança e, tendo em conta, a fortuna crítica anteriormente apresentada, este episódio seria exemplar no sentido de poder servir como evidencia da possível simbiose entre as duas personagens e os conseqüentes processos de quixotização e sanchificação. O que se pretende é analisá-lo a partir de alguns dos princípios que aparecem na Poética de Aristóteles e na Philosophia Antigua Poética de López Pinciano ${ }^{94}$.

\footnotetext{
${ }^{94}$ O preceptista espanhol López Pinciano, publica a versão espanhola da Poética clássica, em 1596. Trata-se, como explica Alberto Porqueras Mayo (1972), de um importante estudo a respeito da composição de textos literários. Em forma de diálogo, de dinâmicas discussões literárias entre três
} 
No tocante ao modo seiscentista de composição e concepção da arte literária, Luisa López Grigera explica que:

desde la antiguidad hasta no hace mucho la formación que recebía el escritor era la misma: teorías retórico-poéticas y comentário de clásicos, cuya imitación se recomendaba como el camino más seguro para lograr al original. (GRIGERA, "Historia textual: Textos literários (Siglo de Oro)", p.1)

A autora apresenta aspectos da perspectiva compositiva dos séculos XVI e XVII muito diferentes das teorias provenientes da filosofia kantiana para a arte, a começar pela idéia de composição e não de criação, de engenho e não de gênio. Dessa forma, em linhas gerais, a visão da composição seiscentista percebe a arte de modo bem diferente da perspectiva literária do século XX. A esse respeito, ilustra Porqueras Mayo

Los preceptistas cuando se enfretaban con el problema de la verdad, según se la interpretase histórica o poéticamente, seguían muy de cerca Aristóteles. Pero muchas veces con un enfoque personal y apasionado del tema, con destellos originales y con alusiones vivificantes a la literatura contemporánea española. ${ }^{95}$

$\mathrm{O}$ ar que se respirava provinha do ideal de conhecer, entender e fazer emergir, desde um processo compositivo, o estilo próprio do escritor. Tendo em vista estas idéias, propõe-se esta perspectiva de análise, mais própria do homem renascentista para a leitura do capítulo XLI, do segundo Quixote. Para tanto, parece necessário, ainda que temporariamente, desconstruir as idéias da sanchificação de dom Quixote e da quixotização de Sancho de Madariaga. Em suma, o objetivo é o de verificar no episódio mencionado como se dá a relação amo/escudeiro, tendo em conta alguns dos princípios de composição próprios dos tempos cervantinos, com a perspectiva de destacar o

personagens, sendo um deles o próprio autor, Pinciano trata de explicitar vários conceitos, entre eles, o de verossimilhança e o de imitação.

${ }^{95}$ PORQUERAS MAYO. Alberto. Temas y formas de la literatura española. Madrid. Ed. Gredos, p.101 
cômico que se dá por meio do rebaixamento de dom Quixote e da elevação de Sancho Pança no palco montado pelos Duques.

\section{ALGUNS PONTOS DE VISTA ACERCA DO CAPÍTULO CLAVILENHO}

É abrangente o leque de estudos acerca do Quixote. A vasta bibliografia enriquecida ao longo dos séculos revela análises pormenorizadas de vários episódios da obra. Não é diferente com o Clavilenho para onde alguns estudiosos tal como, Sarah Finci, dirigiram seu olhar, dedicando atenção aos detalhes que qualificam e quantificam o esquema compositivo proposto no capítulo. Trata-se de mais um cenário organizado, o qual promove o riso no leitor por meio do inusitado ethos das personagens, e, consequentemente, por meio da relação do par quixotesco. A esse respeito, Sarah Finci, na leitura que faz do capítulo, analisa o caráter burlesco, paródico da construção cervantina, afirmando o seguinte: "Haciendo sus protagonistas víctimas de una broma, Cervantes se ríe de la tradición y convierte el episodio de Clavileño en la parodia de los viajes celestes." (“Clavileño” em Gran enciclopedia cervantina, p.2.455) Antes de adentrar na análise propriamente dita do capítulo, cabe historiar alguns pontos de vista críticos que simbolizam o entendimento da crítica cervantina, do século $\mathrm{XX}$, no modo de conceber a relação do par quixotesco no capítulo XLI.

Em linhas gerais, o objetivo desta aventura é desfazer o feitiço do gigante Malambruno contra as distintas senhoras do palácio, que se encontram deformadas por obra de encantadores que fizeram crescer longas barbas em seus rostos. O começo do capítulo relata a ansiedade de dom Quixote com respeito a chegada do cavalo de madeira, pois para o bravo cavaleiro o atraso podia exprimir, como mostra o narrador da história, "que él no era caballero para quien estaba guardada aquella aventura, o que Malambruno no osaba venir con él a singular batalla" (D.Q. II, XLI, 2000,p.327), 
diferentemente de Sancho, que se mostra, em tese, bem pouco interessado na experiência.

Não tarda muito para que, Clavilenho apareça carregado por quatro selvagens, confirmando os desejos de dom Quixote por mais uma aventura e, desconsolando Sancho que sem delongas seja impelido a subir no cavalo de madeira por meio de razão tão bem conhecida, tal como: o governo da ilha Barataria. Para a estudiosa Sarah Finci $^{96}$ a relutância de Sancho em subir no cavalo de madeira é em virtude do medo, ou seja, o medo o paralisa, o faz esquecer suas promessas, como as manifestadas no final do capítulo XL. "Sancho propuso en su corazón de acompañar a su señor hasta las últimas partes del mundo, si es que en ello consistiese quitar la lana de aquellos venerables rostros." (D.Q. II, XL, 2000, p.326).

No entanto, o medo que sente Sancho é superado pelo desejo de ser governador e, sendo assim, imbuídos da aventura, amo/escudeiro montam no cavalo de madeira. Enquanto dom Quixote, de olhos bem vedados, somente sentirá os fatos, em seguida, narrados pelos duques, Sancho Pança, com os olhos un poco descobertos por pura curiosidade própria, dá asas à imaginação e observa fatos do universo das estrelas. Diz Sancho a duquesa:

por junto a las narices aparté tanto cuanto el pañizuelo que me tapaba los ojos, y por allí mire hacia la tierra, y parecióme que toda ella no era mayor que un grano de mostaza, y los hombres que andaban sobre ella, poco mayores que avellanas, porque se vea cuán altos debíamos de ir entonces. (D.Q.II, XLI, 2000, p.335)

O escudeiro entra no jogo cômico estabelecido pelos duques, correspondendo por meio do discurso fantasioso à brincadeira do vôo no cavalo de madeira. Sancho subverte as expectativas de seus burladores e como diz Redondo, "El tonto se ha

\footnotetext{
96 "Clavileño" em Gran enciclopedia cervantina. Vol. III. Madrid. Ed Castalia, 2006 (pgs. 2453-2456)
} 
transformado en discreto [...]" (REDONDO, A..1997,p.443). Ao contrário, dom Quixote não se conforma com o relato inventado pelo escudeiro, uma vez que não combinam com a realidade, com a ordem natural dos acontecimentos e assim dom Quixote relata o que sentiu, não inventa, não imagina. Desse modo, se indigna com Sancho, que segundo o cavaleiro: "Sancho miente, o Sancho sueña". (D.Q. II, p.336) A indignação de dom Quixote combinada com a criatividade de Sancho Pança a respeito da farsa, traz para a relação amo/escudeiro um sentido inverso não do modelo narrativo até então conhecido. Sancho eleva-se como figura cômica, em resposta à burla inventada. Configurada esta inversão nos modelos compositivos das personagens, torna-se o escudeiro protagonista da cena, porque chama atenção dos coadjuvantes da narrativa, assim como do leitor, por sua acuidade.

Dom Quixote fica apagado e rebaixado como protagonista, enquanto que Sancho ascende dominando a cena. A esse respeito afirma Sarah Finci, na Gran enciclopédia cervantina, "Es él (Sancho) quien vive la aventura." (“Clavileño”, 2006, p.2455) Por decorrência do conflito das perspectivas invertidas e o desejo de restabelecer a ordem comum, explica Finci, se configura no capítulo o paralelismo, criado por dom Quixote, entre a "Cueva de Montesinos" e o relato de Sancho. Trata-se, em tese, de um pacto "de verdade", em que um deve acreditar no relato (na verdade) do outro.

Por meio da leitura carnavalesca do capítulo, Redondo afirma que: "Cervantes, una vez más, ha invertido festivamente los esquemas narrativos y las situaciones tradicionales.” (REDONDO, A.,1997, p.437) 
Na Gran enciclopedia cervantina ${ }^{97}, 2006$, a análise empreendida para o capítulo é de autoria de Sarah Finci. A autora principia sua leitura a partir da origem do nome Clavilenho que corresponde a sua constituição, pois se forma a partir de uma peça (clavija) que serve de suporte, de assento para amo/escudeiro, relembrando o corpo de um cavalo. Além de ser feito de madeira (leño) material que favorece a leveza no vôo.

Tendo em conta a análise dos temas que emergem do capítulo XLI, da segunda parte do Quixote, Finci chama atenção para o motivo "del viaje celeste", que se refere a uma questão, segundo a autora, muito antiga. Cervantes se inspirou nessa lenda para compor a história do vôo de amo/escudeiro. Diz a autora: "Cuando se le ocurrió a Cervantes poner una aventura celeste en el Quijote, tenía consciencia de la larga tradición del vuelo." (FINCI, S.. 2006, p.2455) As origens do lendário tema estão em "Pegaso"; em "Hipogrifo", de Orlando Furioso; no "Caballo de ébano" das histórias das Mil e uma noites e em todos os outros contos que podem ser considerados como origem destas histórias. De modo a exemplificar, diz Finci: "podemos mencionar también como antecedentes de Clavileño el caballo volador que se encuentra en las Qisas al-absjã del morisco aragonês Ta'labi, y el Buráq que sirvió de montura al profeta Mahoma." (FINCI. Sarah. Vol.III, 2006, p.2455)

Além do trato do estudo relativo à origem do nome do cavalo de madeira Clavilenho - e a de seus antecedentes um dos principais temas realçados na composição do capítulo-, Finci analisa dois ângulos presentes nas posturas de dom Quixote e Sancho Pança, ou seja, a estudiosa observa o comportamento das duas personagens frente à invenção dos duques. Nesse sentido, Sancho, segundo a autora, ocupa um lugar de destaque na narrativa, porque o escudeiro, por um lado, recorre à sua própria

\footnotetext{
97 “Clavileño”. Vol.III. 2006, p.2454
} 
imaginação e, por outro, surpreende pelo uso de fórmulas discursivas características de seu senhor.

Observados esses aspectos no escudeiro, Sarah Finci depreende duas prováveis maneiras de leitura para as mudanças da personagem. A primeira interpretação se refere à quixotização de Sancho, pois a aventura revela a evolução no caráter da personagem, isto é, Sancho aprendeu. A segunda interpretação como apresenta a autora se fundamenta na estrutura carnavalesca para a construção de amo/escudeiro. A análise se pauta no estudo aprofundado de A. Redondo ${ }^{98}$. No âmbito proposto por Redondo e retomado por Finci, Sancho se eleva, se destaca por seu discurso fantasioso e, desse modo, inverte de papel com o amo em decorrência do processo carnavalesco. No tocante ao processo carnavalesco no capítulo XLI, A. Redondo afirma que:

Las actitudes y los discursos del Caballero de la Triste Figura y de su escudero provocan de tal modo el regocijo de los aristocratas y de su séquito. No obstante, de acuerdo con las normas del sistema carnavalesco puestas de relieve por Bajtín, la risa que surge de los episódios correspondientes es ambivalente, escarnece a todos, aún a los mismos burladores. (1997, p.440)

Como conclusão, Finci acrescenta outro dado relativo à escolha feita por Cervantes pelo fato de a aventura acontecer sob um cavalo e não outro animal qualquer. Para a estudiosa, tal opção é proposital, pois a idéia ilumina no leitor o conhecimento acerca de outros cavalos conhecidos na literatura, tal como: o cavalo de Tróia. Trata-se de dois cavalos semelhantes e por serem de madeira, são também semelhantes, porque ambos servem de meio para o artifício desenhado para os episódios. No entanto, são diferentes no conteúdo, pois um carregara pessoas, enquanto o outro servia de montaria.

\footnotetext{
${ }^{98}$ Otra Manera de Leer el QUIJOTE historia: tradiciones culturales y literatura. Ed.Castalia, 1997
} 
Na edição do Quixote, dirigida por Francico Rico, 1998, sobressai no comentário feito por Heinz-Peter Endress relativo ao tema do cavalo voador. Para Endress trata-se de um conceito difundido pela tradição narrativa, pelos contos e lendas de variadas nações e povos. A partir disso apresenta Endress: "Después de antiguas versiones índias y persas lo encontramos en el cuento arábigo. 'El caballo de ébano' de las Mil y una noches; de allí se divulgó por Europa a través de España." (Don Quijote de la Mancha. Edição dirigida por Francisco Rico, 1998, p.180-181)

Seguindo a pauta, Heinz-Peter Endress historia, a título de exemplo, como o tema do cavalo de madeira fora configurado no romance francês intitulado Cléomadès ou Le cheval de fust e na narrativa espanhola Historia del muy valeroso y esforzado caballero Clamades, hijo de Marcaditas, rey de Castilla, y de la linda Clarmonda, hija del rey de Toscana.(BURGOS, 1521. Referência de Francisco Rico). Na obra italiana o cavalo de madeira aparece voando pelos ares, carregando em sua clavija um casal de apaixonados. Ao ter em mente esta situação, que provavelmente era conhecida não só pelo público leitor/ouvinte do período, mas também por Cervantes fica evidente o viés cômico, paródico identificado no capítulo em questão. Da história francesa deriva a espanhola que também coteja o tema do cavalo voador.

Heinz-Peter Endress evidencia outro tema também identificado na tradição, trata-se do conto de viagens celestiais. Neste cenário protagonizado por Sancho, segundo Endress, ocorre a inversão de papéis por meio do recurso carnavalesco. Sancho, discorre o autor, "representa su triunfo sobre los señores burladores, que no pueden revelar la verdad.” (1998, pgs. 180-182). Endress relaciona de modo ilustre o descenso de dom Quixote na Cueva de Montesinos com a ascendência de Sancho no vôo fantástico como fio condutor para a mudança de papéis entre os protagonistas. Tal 
correspondência contribui para a alteração hierárquica por meio do relato, que se constrói com base em um esquema compositivo próprio de Cervantes. Em suma, somente se restabelece os modelos pré-estabelecidos para amo/escudeiro no final da história quando, por meio de combinação, um tem de acreditar na verdade do outro: "Sancho, pues vos quereis que se os crea lo que hábeis visto en el cielo, yo quiero que vos me creáis a mi lo que vi en la cueva de Montesinos. Y no os digo más. (D.Q. II, 2000, p.337)

Francisco Rodríguez Marín comenta em sua edição crítica do Quixote, de 1948, que as origens do cavalo de madeira, sublinha em notas breves como o tema foi descrito por alguns eruditos da literatura. Em meio às citações de autores, Marín diz do intelectual Menéndez y Pelayo que "tiene por cierto que Cervantes parodió en Clavileño al caballo mágico de Clamades y Clarmonda" (p.214)

Na edição comentada do Quixote por Vicente Gaos, 1985, o autor se dedica destacar diferentes aspectos que constituem o capítulo Clavileño. Os assuntos tratados não estão necessariamente relacionados com os temas possivelmente tirados da tradição por Cervantes ou com a mudança de papéis das personagens. Gaos estuda, segundo critério de valor, temas aleatórios.

Em meio às suas análises, Vicente Gaos eleva a idéia de engenhosidade de Sancho, de burla aos burladores. Em resumo, cita alguns autores conhecidos, como Salvador de Madariaga, para favorecer suas idéias. Refere-se, assim, ao desejo de Cervantes em igualar a Sancho a seus superiores, os duques.

Martín de Riquer no capítulo intitulado "La aventura de Clavileño"99 remete no primeiro momento de sua análise à quixotização de Sancho que, para o autor, se mostra

\footnotetext{
${ }^{99}$ RIQUER.Martín. "La aventura de Clavileño" em Nueva aproximación al QUIJOTE. 1989
} 
por meio da história imaginada e contada pelo escudeiro. O processo ocorrido em Sancho se configura dentro de um processo evolutivo em direção às fantasias cavaleiresca do amo. O segundo ponto observado pelo estudioso refere-se ao tema do cavalo voador. Segundo Riquer o tema do "caballo volador hacía más de tres siglos que figuraba en las novelas caballerescas.” (RIQUER, M., p.127,1989).

Quanto ao tema em si mesmo, Riquer investiga em uma das principais histórias de cavaleiros da literatura francesa, tal como o romance Cléomadès, como a proposta do cavalo voador se consolida. Segundo o autor, o tema provavelmente tem origem no relato persa de Las mil y una noches. Interessante notar o comentário de Riquer acerca do fim estabelecido a esse tipo de tema por Cervantes.

Es de sospechar, pues, que el tema se divulgó por la Europa Cristiana a través de España había de morir, víctima del humor de Cervantes, en estos capítulos del Quijote que el lector de 1615 había de captar en su sentido paródico, ya que de prosificaciones de la citada novela de Adenet li Rois ${ }^{100}$ deriva el libro español Historia de Clamades y Clarmonda, impreso en 1562. (RIQUER, M..1989, p.128)

Em suma, a fortuna crítica a esse respeito é variada e, seria possível acrescentar mais e mais estudos relativos ao episódio, entretanto este breve levantamento é suficiente para evidenciar um dos recursos de estilo utilizado por Cervantes para constituir o capítulo XLI. Com efeito, o autor do Quixote buscou na tradição narrativa espanhola e européia um tema conhecido pelo grande público para a aventura de amo/escudeiro.

REVERSIBILIDADE: PERSPECTIVA DE LEITURA PARA AS MUDANÇAS NA RELAÇÃO AMO/ESCUDEIRO

\footnotetext{
${ }^{100}$ A obra referida de Adenet li Rois, poeta da corte, é Cléomadès, escrita em versos, nas últimas décadas do século XIII, na França.
} 
Interessante notar que por volta dos anos 70 parte dos estudos críticos cervantinos passaram a lutar contra os possíveis anacronismos presentes em muitas das leituras acerca do Quixote e, por conseguinte, relativas ao par quixotesco, fomentando recuperar íntimas relações intertextuais entre a obra de Cervantes e seu repertório discursivo contemporâneo. Frente a esse ideal, os textos, como os de: Maurice Molho; Salazar Rincón; Peter Russell; Eduardo Urbina; Augustin Redondo, Anthony Close, entre outros, buscaram acomodar as mudanças apresentadas na relação do par quixotesco ora pelo viés carnavalesco de leitura, ora se cotejava algum tema de caráter social, político ou cultural relacionado com os tempos em que viveu Cervantes. Para esses especialistas o riso conforma a essência cervantina de composição.

Em meio às concepções de leituras pautadas pelo viés cômico boa parte dos estudos realça o tema da reversibilidade ${ }^{101}$, termo que significa algo passível de reversão. Para alguns escritores como Augustin Redondo ${ }^{102}$, o adjetivo reversível favorece o conhecimento de um dos fios condutores utilizados por Miguel de Cervantes para traçar as tonalidades compositivas contrastadas na relação amo/escudeiro. Dito de outra forma, o caráter reversível em dom Quixote e Sancho Pança possibilita compreender as mudanças no modo de presença das personagens à medida que a trajetória narrativa do par e as circunstâncias exigem.

Buscou-se, neste primeiro momento, apresentar algumas idéias contemporâneas a respeito dos temas e histórias que sugerem o capítulo XLI do segundo Quixote, e também mostrar o viés cômico de leitura como um conceito (de uma ferramenta) bastante recorrente nos estudos cervantinos, a fim de explicar as oscilações na relação, no caráter das personagens quixotescas. A reversibilidade na trajetória narrativa de

\footnotetext{
${ }^{101}$ Novo Dicionário Aurélio da Língua Portuguesa. Revista Ampliada. $2^{\circ}$ ed. Ed. Nova Fronteira, 1986

102 Otra manera de leer el QUIJOTE: historia, tradiciones culturales y literatura.1997, p.196
} 
amo/escudeiro parece explicar as mudanças ocorridas no par, em tese, por se tratar de um recurso também possível na época da composição do Quixote. Desse modo, as idéias de carnavalização assim como as demais leituras e interpretações do episódio dizem respeito a um recurso presente dentro das próprias preceptivas dos séculos XVI e XVII. Nesse caso, o caráter reversível no Siglo de Oro poderia, em certa medida, corresponder, a partir da Poética de Aristóteles e da preceptiva poética de Pinciano, ao recurso para a arte narrativa seria o da peripécia.

Poética de Aristóteles e Philosophia Antigua Pó́tica de López Pinciano: o RECURSO PERIPÉCIA

Os séculos XVI e XVII espanhol se caracterizaram também pela preocupação em relação à técnica literária, ou seja, nessa época, tais conceitos como, imitação, verossimilhança, verdade poética são conceitos importantes para os escritores do período. Os preceptistas espanhóis, assim como o Renascimento em geral, seguindo de certa maneira a pauta iniciada pelos intelectuais italianos, redescobrem a retórica e a poética clássicas como meio concreto de consolidação do fazer literário. Especialistas mais conhecidos, tais como López Pinciano, Cascales e Carvallo re-organizam cada qual, com particular atenção os preceitos contidos na Póetica aristotélica, seu conjunto de preceitos. A esse respeito explica Alberto Porqueras Mayo:

Los preceptistas, cuando se enfretaban con el problema de la verdad, según se la interpretase histórica o poéticamente, seguían muy de cerca a Aristóteles. Pero muchas veces con un enfoque apasionado del tema, con destellos originales y con alusiones vivificantes a la literatura contemporánea espanhola. (PORQUERAS MAYO, A. p.101)

A Poética aristotélica é uma força motriz para os intelectuais da época de Cervantes. Escrita possivelmente na maturidade do filosofo e conhecida por seu caráter 
teórico complexo, organizada com base em questões elementares com respeito ao que contemporaneamente denominamos gêneros e estilos literários, o texto privilegia a tragédia, para onde grande parte dos esquemas compositivos está direcionada.

A Poética trata de reconhecer o elemento "Peripécia" como parte/recurso qualitativo do mito complexo, sendo um dos aspectos que formam a tragédia. Neste tipo de mito a ação muda ou pelo reconhecimento ou pela peripécia. Explica a Poética: "Dos mitos, uns são simples, outros complexos, porque tal distinção existe, por natureza, entre as ações que eles imitam.” (SOUSA, Eudoro.(trad.) ${ }^{103} .4^{\circ}$ ed. p.117) Trata-se, pois, de um recurso compositivo importante para a poesia, que a qualifica, iluminando a estrutura em versos ou em narração delineada pelo autor. Com respeito à adequação compositiva da "peripécia", é preciso, segundo Aristóteles, que a peripécia surja da "própria estrutura interna do mito, de sorte que venham a resultar dos sucessos antecedentes, ou necessária ou verossimilmente.” (p.117). Quanto ao seu significado, diz o pensador grego: "é a mutação dos sucessos no contrário, efectuada do modo como dissemos; verossímil e necessariamente." (SOUSA, Eudoro.(trad.) ${ }^{104} .4^{\circ}$ ed. p.118)

López Pinciano, segundo Alberto Porqueras Mayo, publica em 1596 "una importante Poética" (Temas y Formas de la Literatura Española, p.102)

Intitulada Philosophía antigua poética, texto amplo, organizado em treze "Epístolas", divididas em três volumes, as quais compreendem diferentes temas sobre a arte poética. A disposição dos temas ocorre por meio do diálogo entre três personagens, sendo uma delas o próprio autor. Com respeito à estrutura utilizada por Pinciano, Porqueras Mayo observa: "Esta característica es importante y se repite en las otras

\footnotetext{
${ }^{103} \mathrm{O}$ tradutor tem por obra de origem o texto grego editado por Augusto Rostagni e da versão árabe (Gudeman). Mais detalhes pg. 10 de seu trabalho.

${ }^{104} \mathrm{O}$ tradutor parte do texto grego editado por Augusto Rostagni e da versão árabe (Gudeman). Mais detalhes pg. 10 de seu trabalho.
} 
Poéticas de Carvallo y Cascales; polémicas dialogadas, con un personaje que tiene el nombre - y representa, a veces, su pensamiento - de autor de la obra.”(p.102). Certamente Pinciano conhecia a Poética de Aristóteles, pois remete às teorias do filósofo com grande acuidade. O modo como lida com as questões ilumina as novidades teóricas pretendidas pelo pensador espanhol.

Com respeito ao recurso da peripécia, López Pinciano desenvolve o tema na "Epístola V", volume II, onde trata em especial das partes que constituem a fábula. Para o autor, o poema tem por essência a fábula e a linguagem. No que tange à fábula existem dois tipos: a fábula simples e a fábula composta. Trata-se de ser composta (a fábula) quando tem como recurso a peripécia. Explica Pinciano: "la fábula o es simple o compuesta; simple se dize la que no tiene agniciones ni peripécias; y compuestas la que, o tiene agniciones, o peripécias, o todo junto.” (“Epístola quinta”, 1973, p.25)

A peripécia, por sua vez, se explica por meio de "una mudança súbita de la cosa en contrario estado que antes era." (“Epístola V”, 1973, p.25-26, grifo nosso) O autor separa em dois tipos a peripécia. O primeiro tipo consiste em algo bom que se tornou mau, o segundo tipo se refere ao contrário. Afirma Pinciano:

Ay dos espécies de peripecias: la vna que passa del mal en bien, como ésta que auemos referido; y la otra, al contrario, de bien en mal, qual se puede ver en los más de los trágicos antiguos (Vol. II, 1973, p.26)

O filósofo - Aristóteles - possibilita também a Pinciano utilizar a peripécia em ações cômicas, nesse sentido o projeto literário do médico espanhol se diferencia da Poética clássica, onde não há considerações acerca dessa possibilidade compositiva. Cabe notar, por meio das palavras de Pinciano, a funcionalidade da peripécia na ação 
cômica. Explica: "la acción cómica siempre tiene peripecia al fin, que passa de infeliz a feliz" (p.26)

Em linhas gerais, o cenário apresentado teve o objetivo de trazer o conceito atribuído à peripécia por Aristóteles e, séculos depois, por Pinciano. Com relação ao episódio do Quixote em questão, ao que tudo indica, a utilização da peripécia na comédia reflete uma das possibilidades narrativas que, na época de Cervantes possibilitava a inversão de papéis entre amo e escudeiro.

\section{UM MODO DE LEITURA}

"Pero veis aquí cuando a deshora entraron por el jardín cuatro selvajes, vestidos todos de verde yedra, que sobre sus hombros traían un gran caballo de madera." (D.Q. II. 2000, p.327)

Cervantes, ao que parece, encontrou nas Poéticas e nos textos as diretrizes necessárias para a aventura de Clavilenho. Com engenhosidade, o capítulo principia descrevendo o estado de ânimo de seus protagonistas. Em seguida, tem-se a chegada de Clavilenho que constitui a ação principal do capítulo. A figura do cavalo de madeira remete ao leitor da época o repertório narrativo com respeito à idéia.

O mecanismo de rememoração e diálogo com outras histórias que tratam o tema favorece o riso, o cômico identificado no capítulo, uma vez que, como observou Heinz na edição comentada do Quixote, uma das principais funções dos cavalos de madeira voadores era a de servir de meio para a viagem de amantes. A esse respeito explica o autor com base no romance em verso francês Cléomadès: "montado sobre un caballo de madera provisto de cuatro clavijas y fabricado por el Rey moro Comprart de Bujía, el héroe vuela por los aires con su amada, la princesa Clarmondine.” (1998, pgs. 180-181) 
Dom Quixote e Sancho Pança, ao longo da trajetória narrativa, se apresentam de maneira diversa. A primeira perspectiva para a dupla reside no fato de dom Quixote em principio estar certo dos benefícios de sua missão. O cavaleiro acredita na proposta dos duques por influência do universo fantasioso, no qual grande parte de suas aventuras estão confiadas. Com efeito, Sancho, a contragosto, somente após o diálogo "de suborno" com o duque, aceita subir nas ancas do cavalo de madeira. Embora dom Quixote sinta medo, consegue disfarçar as inseguranças que na transparência inerente a Sancho se apresentam em tom de desconfiança. O escudeiro desconfia da veracidade da aventura: “- Señor, ¿cómo dicen éstos que vamos tan altos, si alcanzan acá sus voces, y no parecen sino que están aquí hablando, junto a nosotros? (D.Q.II, p.332)

A segunda perspectiva considerada para o comportamento do amo/escudeiro incide nas fantasiosas visões narradas por Sancho e na realista descrição das sensações relatadas por dom Quixote. Antes, dom Quixote imaginava e confiava na perigosa empreita, vangloriando-se, enquanto que Sancho, com medo e desconfiado não se propunha a seguir o amo.

O escudeiro inverte de papel com o amo por meio do discurso fantasioso característico a dom Quixote, respondendo de forma inusitada às expectativas de seus burladores, os quais não esperavam tão engenhosas palavras. Ao ouvir tão insólito discurso, dom Quixote se mostra mais realista e pouco idealista por entender que os fatos narrados eram incomuns, pouco críveis. O que Sancho conta a respeito da viagem suplanta a imaginação tão característica de dom Quixote.

Mais parecido a Sancho, dom Quixote relata os acontecimentos bem superficialmente, não ultrapassa o plano das sensações, que emerge dos artifícios criados pelos duques. Diz dom Quixote: "Bien es verdad que sentí que pasaba por la 
región del aire, y aun que tocaba a la del fuego, pero que pasásemos de allí no lo puede creer[...]" (D.Q. II, p.336)

Os papéis sofrem inversão, Sancho sonhador, dom Quixote realista. Esta situação invertida caracteriza muitos capítulos da trajetória dos protagonistas em decorrência do estilo cervantino. A peripécia possibilita a inversão da ação esperada para a atitude das personagens de forma a contribuir para o desenlace inusitado, quando dom Quixote, mais uma vez, se mostra descrente com respeito ao relato de Sancho sobre o vôo no cavalo de madeira. O cavaleiro, diante da impossibilidade de conciliação, faz um pacto com Sancho acerca do ocorrido no castelo dos duques e dos acontecimentos na cova de Montesinos. Diz o cavaleiro: “- Sancho, pues vos queréis que se os crea lo que habéis visto en el cielo, yo quiero que vos me creáis a mí lo que vi en la cueva de Montesinos. Y no os digo más.” (D.Q.II, p.337)

A peripécia é, como cita Pinciano "vna mudança súbita de la cosa en contrario estado"(p.25). "La cosa" que diz o estudioso em tese significa um estado, uma situação ou um acontecimento que se altera. Pode-se entender que no capítulo analisado a peripécia é o mecanismo impulsionador para a inversão brusca dos modelos estabelecidos para amo/escudeiro (a inversão se apresenta por meio do discurso), apresentando os acontecimentos de modo inverso. Trata-se de uma mudança de estado de ânimo, por um lado, a fim de estabelecer o cômico, por outro, de desestabilizar, em certa medida, o jogo organizado pelos duques, os quais esperavam ver alimentados em dom Quixote suas ilusões e ver em Sancho Pança ora algum comentário incrédulo, ora certa demonstração de medo, ora um discurso pouco rebuscado e desconcertante.

Nesse sentido, com base nas premissas de Pincinao, pode-se dizer que a peripécia identificada é a que se configura para a ação cômica cujo final é feliz. 
Em suma, há duas questões relacionadas com a estrutura do Clavilenho: a primeira se refere aos temas da tradição narrativa espanhola elencados pelos trabalhos críticos para fundamentar o capítulo; a segunda, diz respeito ao recurso da peripécia que contribui para o desenlace referente à aventura amo/escudeiro. A partir da Poética aristotélica verifica-se o elemento qualitativo como enriquecedor da ação, ou seja, a partir do tema do cavalo voador ou viagem celeste o recurso da peripécia se configura. Dito de outro modo, a composição do capítulo, com base nesses dados, poderia ser lida da seguinte forma: dentro da história do cavalo voador a peripécia exerce a função de promover a inversão de papéis característicos aos protagonistas, favorecendo assim a instabilidade do caráter comum de dom Quixote e Sancho.

Para concluir, o fio tênue que, por algum tempo, delineou Sancho como realista e dom Quixote como idealista se desfaz neste quadro, onde as expectativas são sobrepujadas pela técnica narrativa. Em outros termos, as mudanças ocorridas em dom Quixote e Sancho Pança podem ser também vistas por meio da utilização da "peripécia" como forma a colaborar com as oscilações ocorridas no par quixotesco para a produção do feito cômico. A "influência mútua" que disse Salvador de Madariaga e outros intelectuais,pode ser explicada por diferentes recursos técnicos literários e não exatamente pelas transformações simbióticas das personagens. De qualquer modo, identificar nas preceptivas poéticas da época do Quixote uma forma de leitura possibilita ao leitor vislumbrar sistemas literárias próprios que se distanciam das concepções artísticas iniciadas no século XIX. 


\section{CONSIDERAÇÕES FINAIS}

Diante do cenário organizado mostrou-se evidente a repercussão dos conceitos da sanchificação de dom Quixote e da quixotização de Sancho. Não se trata de idéia inventada e anunciada pela primeira vez pelo o autor espanhol, mas sim considerada e organizada cuidadosamente pela primeira vez por ele. Por isso, quando se menciona evolução, simbiose, influência mútua, mudança no caráter de dom Quixote e Sancho Pança, em seguida, se pensa no estudo de Madariaga.

Quase todo leitor, seja ele estudioso de literatura ou simplesmente um leitor, ao conhecer ou ao se aproximar do par quixotesco convive com os valores dicotômicos presentes no próprio processo compositivo das personagens.

Ao longo do trabalho algumas considerações foram sendo feitas e se colocadas aqui novamente acabariam tornando-se redundantes, consequentemente, enfadonhas. Entretanto, cabe, se possível for, uma vez mais sublinhar o objetivo deste trabalho que foi o de mostrar essencialmente a repercussão de uma idéia dentro de um cenário onde as análises críticas apresentadas partem de uma perspectiva contemporânea da obra literária que evidenciam as tendências estéticas e filosóficas próprias de nosso tempo. Em resumo, os parâmetros utilizados por esses estudiosos do Quixote refletem, de modo bem particular, as leituras, ou melhor, as muitas leituras de uma época frente a um tema. Nada más. 


\section{BIBLIOGRAFIA}

ALONSO. Dámaso. "Sancho-Quijote; Sancho -Sancho", em Del siglo de oro a este siglo de siglas. 2ed. Madrid. Ed. Gredos.1968

ALVAR EZQUERRA. Alfredo; SEVILLA ARROYO, Florencio (coordenadores). Gran enciclopedia cervantina. Vol. III. Madrid. Ed Castalia, 2006 (pgs. 2453-2456)

ANTHROPOS. "Revista de Documentación Científica de La Cultura". Miguel de Cervantes en su obra: antologia, selección de estudios y documentación. Ed.Anthropos. Setembro 1989.

ARISTÓTELES. A Poética Clássica. São Paulo, Ed. Cultrix, 2005 Poética.Trad. Eudoro de Souza. Porto Alegre, Ed. Globo, 1966

AUERBACH, Erich. "La Dulcineia encantada", Mimesis. La representación de la realidad en la literatura occidental, México: Fondo de Cultura Económica, 1950 AVALLE-ARCE, Juan Bautista. Nuevos deslindes cervantinos. Barcelona, Ariel, 1975 AVALLE-ARCE, Juan Batista; RILEY, E.C. (editores). "Don Quijote" em Suma Cervantina. Madri, Ed. Castilla, 1973

AYALA.Francisco. "La invención del Quijote". Cervantes e Quevedo, Barcelona, Seix Barral, 1974

AZAÑA. Manuel. "Cervantes y la invención del Quijote" in Obras completas. Mexico, Oasis, 1966-1968

BERTRAND, J.J.A.Cervantes en el país de Fausto. Madrid, Cultura Hispánica, 1950

BONATI. F. Martínez. “El Quijote: juego y significación”, DISPOSITIO, vol. III, nº 9 (1978) 
BONNICI,Thomas; ZOLIN, Lúcia Osana (orgs). Teoria Literária: abordagens históricas e tendências contemporâneas. Maringá, Eduem, 2003

CANAVAGGIO, Jean. Historia de la literatura española. Barcelona, Editorial Ariel, 1994, Tomo II

. “Alónso López Pinciano y la estética literaria de Cervantes en

el Quijote" em Anales cervantinos, VII (1958)

Cervantes. (Tradução de Rúbia Prates Goldoni e trad. dos excertos da obra de Cervantes Sérgio Molina). São Paulo, Ed. 34, 2005

CARVALHO.Castelar de. Para compreender Saussure. Rio de Janeiro, Ed. Vozes, 2000

CRUZ. Anne J. "La desaparición de don Quijote: Unidad estructural y transformación de personajes en el Quijote”. Actas del segundo coloquio internacional deasociació de cervantistas. Alcalá de Henares. Ed. Anthropos, nov., 1989

CASALDUERO,Joaquín. Sentido y forma del “Quijote” (1605-1615), Madrid, Ínsula, 1975

CASTIGLIONE.Baldassare. El cortesano. Ed. De Mario Pozzi. Trad. de Juan Boscán. Trad. De la introducción y notas de Maria de las Nieves Muñiz. Madrid. Cátedra, 1994

CASTRO, Américo. El pensamiento de Cervantes. Barcelona: Moguer, 1972 (1925). Nueva edición ampliada y con notas del autor y de Julio Rodríguez- Puértolas

CERVANTES, Miguel de. Don Quijote de la Mancha I. Madrid, Cátedra, 2000 . Don Quijote de la Mancha II. Madrid, Cátedra, 2000

. Don Quijote de la Mancha, Volume complementar.

Barcelona, Edição Instituto Cervantes, dirigida por Francisco Rico, 1998

.El ingenioso hidalgo Don Quijote de la Mancha II. Madrid.

Gredos. Edição crítica e comentário de Vicente Gaos, 1985 
CERVANTES. Miguel de. El ingenioso hidalgo Don Quijote de La Mancha. Tomo VI, Madrid. Nova edição crítica com comentários ampliados e notas novas de Francisco Rodríguez Marín, 1948 . Entremeses. Madrid, Cátedra, 1989.

CHEVALIER, Maxime. "Sobre crítica del Quijote". Actas del segundo coloquio internacional de la asociación de cervantistas. Alcalá de Henares, 1989

CHKLOVSKI, V. “A Arte como Procedimento". Em: EIKHENBAUM, B. em Teoria da literatura:formalistas russos. Porto Alegre: Globo, 1976, p.39-56

CLOSE, Anthony. "La critica del Quijote desde 1925 hasta ahora”. Cervantes. Centro de estudios cervantinos, 1995 La concepción romántica del Quijote. Trad. Gonzalo G. Djembé.

Barcelona, Crítica, 2005

CITELLI. Adilson. Romantismo. 3 ed.,São Paulo, Ática,1993

DOREN. M. Van. "La profesión de Don Quijote”. México, Fondo de Cultura Económica, 1973

DOTRAS BRAVO, Alexia. BRAVO DOTRAS. Alexia. Los trabajos cervantinos de Salvador de Madariaga Historia de una idea doble: sanchificación y quijotización. Alcalá de Henares (Madri), Centro de Estudios Cervantinos, 2008

ESCRIBANO SÁNCHEZ. Federico, PORQUERAS MAYO. Alberto. Preceptiva Dramática Española del renacimiento y el Barroco. Madrid. Ed. Gredos, 1965

EIKHENBAUM;CHKLOVSKI;JAKOBSON;TOMACHVSKI,TROTSKY;JIRMUNSK I;PROPP,BRIK,TYNIANOV,VINOGRADOV. Teoria da literatura: formalistas russos. (Tradução Ana Mariza Ribeiro Filipouski; Maria Aparecida Pereira; Regina L. Ziberman; Antônio Carlos Hohlfeldt) 2ed., Porto Alegre, Editora Globo, 1976

FUENTES. Carlos. Cervantes o la crítica de la lectura. México, 1976

GAOS, V. "El primitivo plan del Quijote" em Temas y problemas de la literatura española, Madrid, Guadarrama, 1959 
GRIGERA. Luisa López. La retórica en la España del Siglo de Oro. Salamanca: Ediciones Universidad de Salamanca, 1994 ."Historia textual: Textos literários (Siglo de Oro)" em Historia textual de la lengua española. (não há mais referência bibliográfica.)

HANSEN. João Adolfo. "O discreto". Libertinos Libertários. São Paulo, Companhia das letras. 1996

HEGEL.G.W.Friedrich. Estética. (Tradução de Álvaro Ribeiro; Orlando Vitorino) Lisboa, Guimarães Editores, 1993

HERMÓGENES. Sobre las formas de estilo. Introducción, traducción y notas de Consuelo Ruiz Montero. Madrid: Gredos, 1993.

HUARTE DESAN JUAN, Juan. Examen de ingenios para las ciências. Ed. de Guillermo Serés. Madri: Cátedra, 1989

JOHNSON.Carroll B. "La construcción del personaje en Cervantes", em Cervantes: Bulletin of the Cervantes Society of America, 8 special issue, no 15, vol.1 1995, pgs.125

KANT. Immanuel. Crítica del Juicio: seguida de las observaciones sobre el asentimiento de lo belo y de lo sublime. Tradução Alejo García Moreno; Juan Ruvira. Madrid, Librerías de Francisco Iravedra; Antonio Novo,1876.

KANT. Emmanuel. Crítica de Razón Pura. Tomo I. Trad., noticia preliminar Juan B. Bergua. 2ed. Madrid. Artes Gráficas Luna, 1970.

KANT.Emmanuel. "Observações sobre o sentimento do belo e do sublime ensaio sobre as doenças mentais".Trad. Vinicius de Figueiredo. (Texto original em alemão: Beobachtungen über das Gefuhl des Scönen und Erhabenen - Versuch über die Krankheiten des Kopfes, Vol. II).Campinas. Papirus, 1993.

LUKÁCS. Georg. Teoria do romance. Lisboa, Presença. (não há mais indicação bibliográfica) 
LUMSDEN-KOUVEL.Audrey. "Desde la venta del engaño al castillo del desengaño: Ensaio de topología estructural en el Quijote”, en Alan Gordon y Evelyn Rugg (eds.), Actas del sexto congreso internacional de hispanistas celebrado en Toronto. 1977

MADARIAGA, Salvador. Guía del Lector del "Quijote". 3ed. Madrid, Espasa-Calpe, 1987. A primeira versão da obra apareceu em La Nación, de Buenos Aires entre 1923 e 1925. Na Espanha pela editora Espasa-Calpe em 1926

MÁRQUEZ VILLANUEVA. Fernando. "La génesis Literaria de Sancho Panza" em Fuentes Literárias Cervantinas. Madrid, Ed. Gredos, 1973

MARTINEZ-BONATI. Felix. "El Quijote: Juego y Significación”. Revista Dispositio, Vol.III, Nº 9 , 1978, pgs.315-336

MARTÍN MORÁN, José Manuel. Don Quijote esta sanchificado el des-sanchificador que lo re-quijotice....Bulletin Hispanique. Vol.94, N.1, 1992

MAYO PORQUERAS.Alberto. "Algunas observaciones sobre el quijotismo y la generación del 98 (Notas sobre las actitudes de Unamuno, Ortega, Madariaga y Maeztu)" em Estudios sobre Cervantes y la Edad de Oro. Alcalá de Henares: Centro de estudios cervantinos, 2003, págs. 101-112

MONTERO REGUERA, José. "El “Quijote” y la crítica contemporánea”. Alcalá de Henares, Centro de Estudios Cervantinos, 1997

MOLHO. Mauricio. "Raíz folklórica de Sancho Panza" em Cervantes: raíces folklóricas. Madrid, Ed. Gredos, 1976

NÓBREGA. Francisco Pereira. Compreender Hegel. 3 ed., Petrópolis, Ed. Vozes, 2005

ORTEGA Y GASSET. José. Meditaciones del QUIJOTE. Madrid, Ed.Catedra, $4^{\circ}$ ed., 1998

PELAYO MENÉNDEZ. Marcelino. "Cultura Literaria de Miguel de Cervantes y Elaboración del Quijote", em Estudios y Discursos de Crítica Histórica y Literária, Madrid, 1941, Vol.1, p.355

PINCIANO, López. Philosophia antigua poética. Ed. Alfredo Carballo Picazo, Madrid, CSIC, 1973 
PORQUERAS MAYO. Alberto. "Algumas observaciones sobre el quijotismo y la generación del 98(Notas sobre las actitudes de Unamuno, Ortega, Madariaga y Maeztu)" em Estudios sobre Cervantes y la Edad de Oro. Alcalá de Henares. Centro de estúdios cervantinos, 2003, pgs. 111-112 Temas y Formas de la Literatura Española. Madrid.

Ed. Gredos, 1972

PREDMORE. Richard L. El mundo del Quijote. Madrid, Ínsula, 1958

REDONDO, Agustín. Otra Manera de Leer el Quijote historia: tradiciones culturales y literatura. Ed.Castalia, 1997

REDONDO, Agustín. “Acercamiento al Quijote desde una perspectiva histórico-social” em Cervantes. Alcalá de Henares, Centro de Estudios Cervantinos, 1995

RICO Francisco. Historia y Crítica de la literatura española. Barcelona, Ed. Crítica, 1978

RILEY. E. Introducción al Quijote. Barcelona, Ed. Crítica, 1990

RILEY.E. Teoría de la Novela en Cervantes. Trad.C.Sahagún. Madrid, Taurus, 1971

RIQUER. Martín de. "La aventura de Clavileño" em Nueva aproximación al Quijote. Ed. Teide, 1989

RIVERO. A. Sánchez. “Las ventas del Quijote”, Revista de Occidente, XXVII, (1927)

ROSALES. Luis. Cervantes y la Libertad. Volume I. Madrid, Ed. Cultura Hispanica, 2 ed., 1985

RUSSELL, Peter E. "Don Quijote y la risa a carcajadas". Temas de la Celestina y otros estudios. Trad. de Alejandro Pérez, Barcelona: Ariel, 1978

SALAZAR RINCÓN. Javier. "El personaje de Sancho Panza y los lectores del siglo XVII" em Asociación Internacional de Hispanistas, 1999

SALINAS. Pedro. "Lo que debemos a Don Quijote" em Ensayos de literatura hispánica. Madrid, Taurus, 1962, pgs.50-58 Disponível em 
http://sisbib.unmsm.edu.pe/BibVirtualdata/publicaciones/umbral/v05_n08/a08.pdf. Acesso em 02/març/2009

SAN JUAN, Huarte. Breviarios del pensamiento español. Madrid, Ed.Fe, 1944 Examen de ingenios para las ciencias. Madrid, Ed.Nacional, 1976

SÁNCHEZ RIVERO.Angel. "Contestación”. Madrid, em Revista de Occidente, XVII, 1927, pgs.291-316

SLETSJÖE, L. Sancho Panza, hombre de bien. Madrid, Insula, 1961

SPITZER. Léo. Lingüistica e Historia Literária. Madrid. Ed. Gredos, 1974

SKLOVSKI.Victor. Sobre la Prosa literaria: reflexiones y análisis. Barcelona, Ed.Planeta, 1971

SKLOVSKIJ. Viktor. Una teoría della prosa: l'arte come artificio, la construzione del racconto e del romanzo. Bari, Ed. Leonardo da Vinci, 1966

TODOROV. Tzevetan. “A herança metodológica do formalismo”. Em: TODOROV, T. Poética da prosa. Lisboa: Edições 70, 1979, pgs.11-31 Estruturalismo e poética. Trad. José Paulo Paes. São Paulo. Ed. Cultrix, 1970

TORRENTE BALLESTER.Gonzalo. El Quijote como juego. Madrid. Ed. Labor, 1975 UNAMUNO. Miguel de. Vida de Don Quijote y Sancho. Madrid, Ed. Espasa-Calpe, 1971

URBINA. Eduardo. El sin par Sancho Panza. Parodia y Creación, Barcelona, Anthropos, 1991

VIEIRA, M. Augusta da Costa. O dito pelo não dito: Paradoxos de Dom Quixote. São Paulo, Edusp/ Fapesp, 1998

(org.). Dom Quixote a letra e os caminhos. São Paulo,

Edusp, 2006 
VILlANUEVA MÁRQUEZ, Francisco. Personajes y temas del "Quijote”. Madrid, Taurus , 1975

VILLANUEVA MÁRQUEZ. Francisco. "La génesis literaria de Sancho Panza" em Fuentes literarias cervantinas. Madrid, Gredos, 1973.

WILlIAMSON, Edwin. El Quijote y los libros de caballerías. Trad. María Jesús Fernández Prieto, Madrid, Taurus, 1991 